\title{
Upstream Water Piracy Impact on the Aquatic World and Human Dimension -Some Water Piracy Curses
}

\author{
Miah Muhammad Adel \\ Professor of Physics, Astronomy, and Environmental Sciences, Department of Chemistry and Physics, Interdisciplinary Sciences Research \\ Center, University of Arkansas at Pine Bluff, 1200 North University Drive, Pine Bluff, AR 71601 \\ *Corresponding Author: adelm@uapb.edu
}

Copyright $@ 2013$ Horizon Research Publishing All rights reserved.

\begin{abstract}
Out of the myriads of downstream ecocide effects in the Bangladesh Ganges basin from India's upstream water piracy, attention has been given on the extinction of the aquatic species that supplied people's cheap nutritional intakes and seasonal to permanent livelihood. In the Ganges basin, surface water bodies consisted of the Ganges, its distributaries and their canals linking to floodplains, and privately owned ponds and ditches. Most of the ponds and all the ditches would flood in the rainy season, and along with the floodplains, would turn into a vast sheet of water body allowing mingling of fishes from different sources. People used to have calcium and the indispensable animal protein nutrient as well as income supplement from the cheap fish resources. Some people would make fishing gears out of threads and bamboo strips, a generations-old home-grown technology. India's indiscriminate actions of violations of water rights for the downstream ecosystem challenge the UNDP's cottage industries-based rehabilitation programs in the third world countries. Attempts to restore the lost wetland ecosystems require dredging of the Bangladeshi silted riverbeds and canals followed by the destruction of river barrages to return the pirated water. India's irresponsible actions make her bear the dredging costs and pay monetary compensation to Bangladesh in retrospective effects. Deprivation of water has a slower but much wider ecocide problem than the weapon of mass destruction. International sanctions should be in placed upon India and all other disregarders of downstream ecosystem's water rights.
\end{abstract}

Keywords Farakka Barrage, Ganges River, Hooghly River, Water Piracy, Ecosystem, Surface Water Resources, Nutrition For Fishes, Fishing Gears

\section{Introduction}

The south Asian country Bangladesh is mostly wetland (Fig. 1). Bangladesh and India share 58 international rivers. About $50 \%$ of them have one or more constructions on the upstream for pirating water by upstream India (Fig.2). The largest of these water diversion constructions is the Farakka Barrage built on the Ganges about $18 \mathrm{~km}$ from the international border. It started operation in 1975 (Fig. 3). The objective was to pirate the Ganges water flowing through Bangladesh to establish No. 1 year-round navigable route from the southeastern border of Bangladesh across India to her southern end Allahabad (Fig. 4) for which India raised a false hue and cry, in the mid-seventies right after the creation of Bangladesh, for enhancing the navigability of the Calcutta Port. However, the Calcutta Port located at the mouth of the River Hooghly that branched off from the Ganges as a seasonal canal and later, turned downstream into a giant river being fed by the discharges from the tributaries was affected, if at all, by India's own actions of damming the tributaries and sub-tributaries of the River Hooghly (Fig. 5). These constructions blocked the timely adequate discharges to the Hooghly weakening its downstream flow into the Bay of Bengal. Since the test-run of the Farakka Barrage in 1975, India had been pirating the Bangladesh Ganges basin ecosystem's elixir water for about ten years (Fig. 6) disregarding Bangladesh's demands, outside the temporary water-sharing agreements signed at India's pleasure and under the cornered Bangladesh's continued insistence for her least survivability. India agreed to sign a longer-term 30-year watering sharing agreement in 1996 after more than 100 meetings between the two nations. Some of the major downstream consequences that developed in these long years' of $60 \%$ water piracy from the downstream Ganges ecosystem's founding and sustaining water include (i) water scarcity in surface water bodies, the habitat of a variety of aquatic species, (ii) little or no recharging of groundwater, (iii) forced dependence on groundwater, (iv) public deprivation of catching fish from surface water resources for the cheapest indispensable nutritional supplements and livelihood supports, (v) increased malnutrition among common people, (vi) generation of extreme climate causing fatalities and environmental diseases, (vii) increased frequency of inland and in-sea tornado generation resulting in lives and property losses and lightning-hit deaths, (viii) unavailability of facilities for water sports, recreational, and 
religious rituals, (ix) depletion of tens of kilometers long cheap inland water ways putting pressure on roads and highway transportations and causing frequent fatal accidents, ix) inland inaccessibility of flood season aquatic species from the sea, (xi) habitat depletion of migratory birds, (xii) arsenic contamination of ground water, (xiii) people's sufferings from arsenicosis, (xiv) break-off of families, (xv) environmental pollution from indiscriminate disposal of arsenic sludge, (xvi) arsenic poisoning of the food chain, (xvii) inland intrusion of the salinity front, and (xviii) coastal erosion (Adel, 19999a, 199b, 2000a, 200b, 2001, 2002, 2003, 2004a, 2004b, 2005, 2008a, 2008b, 2008c, 2012a, 2012b, 2013a, 2013b, 2013c; Begum, 1988; Bindra, 1982; Haque, 2003; Miah, 1996a, 1996b, 1996c; Miah and Samad, 1996). This article focuses on the loss of the fish resources, and its impact on the people's nutrition and their livelihood loss and life styles.

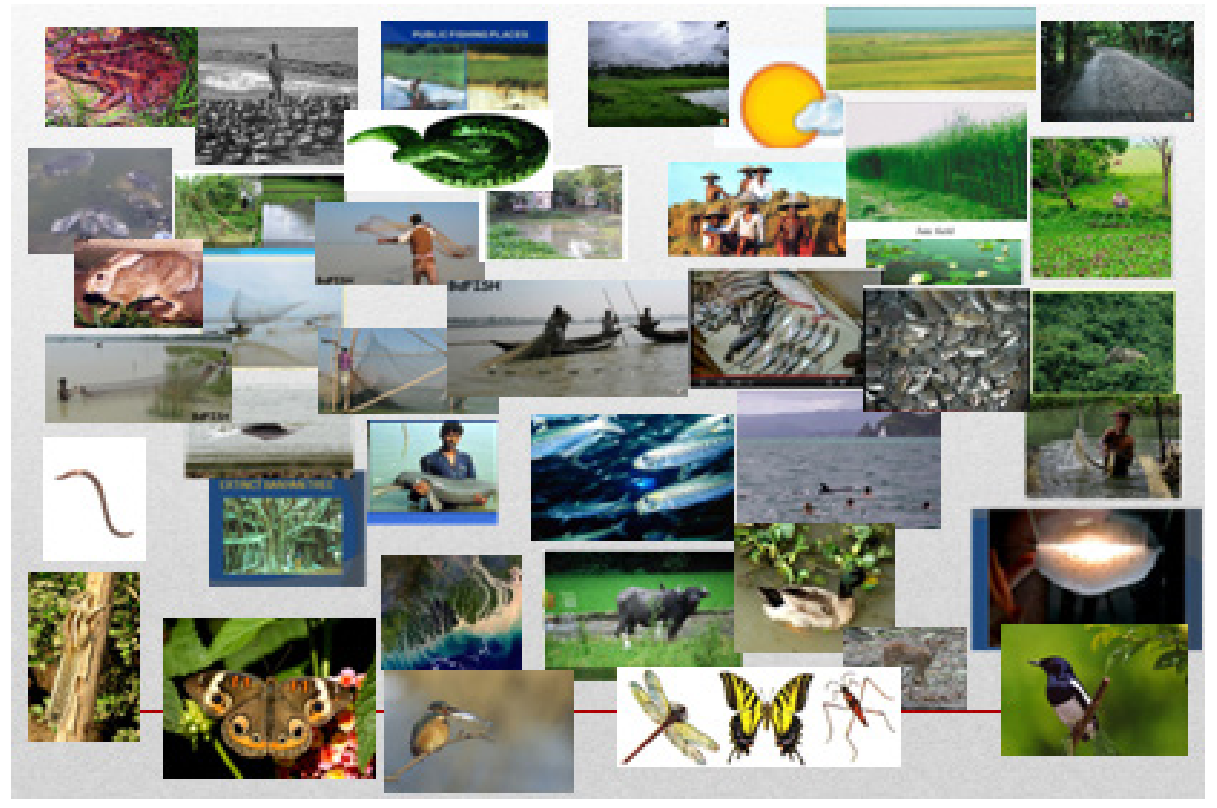

Figure 1. Glimpses of the victimized riverine ecosystem in the Ganges basin. The sun, land, water bodies, aquatics, amphibians, domestic and wild animals, trees, plants, birds, insects, micro-organisms, etc. etc. form the complex wetland ecosystem (courtesy of Panoramabangladesh and other sources for the contributions)

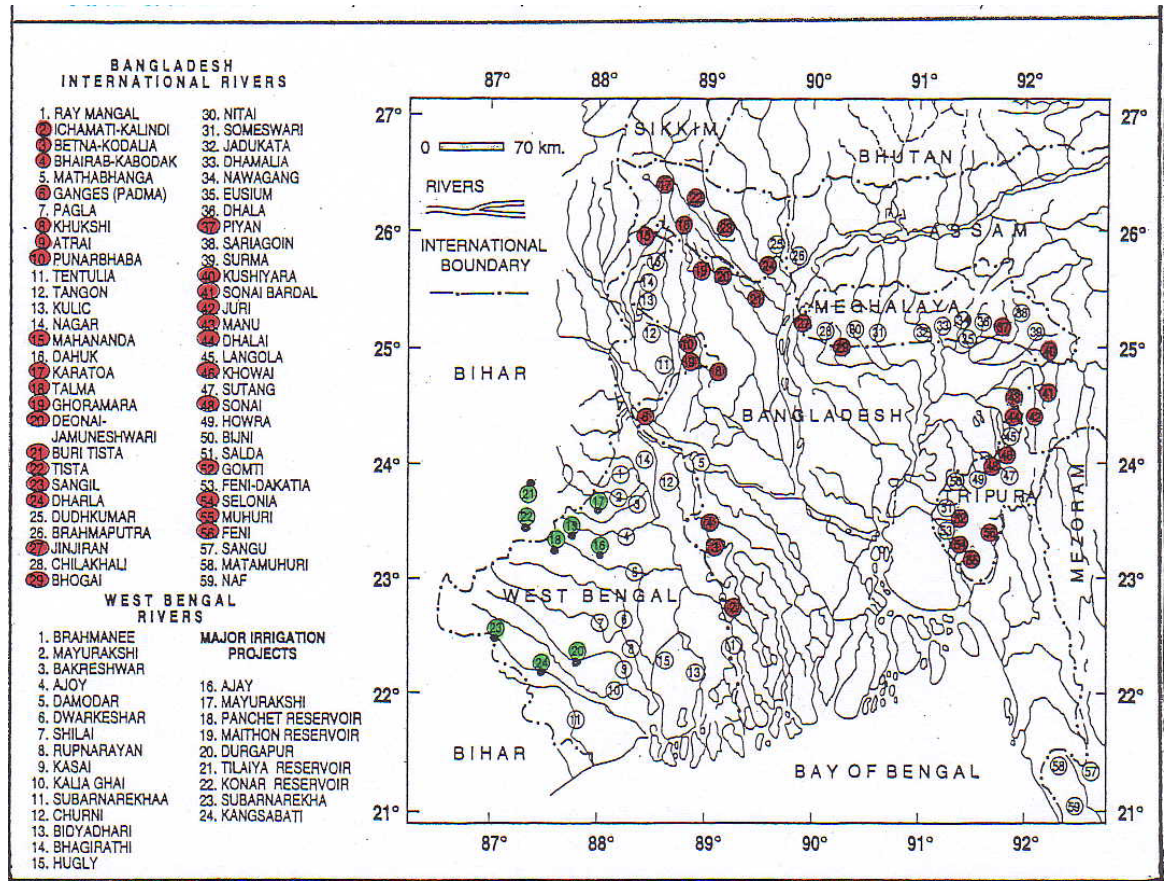

Figure 2. The fifty-eight international rivers which are common to both India and Bangladesh. India's water piracy takes place in more places than marked with red circles (Adel, 2001). 


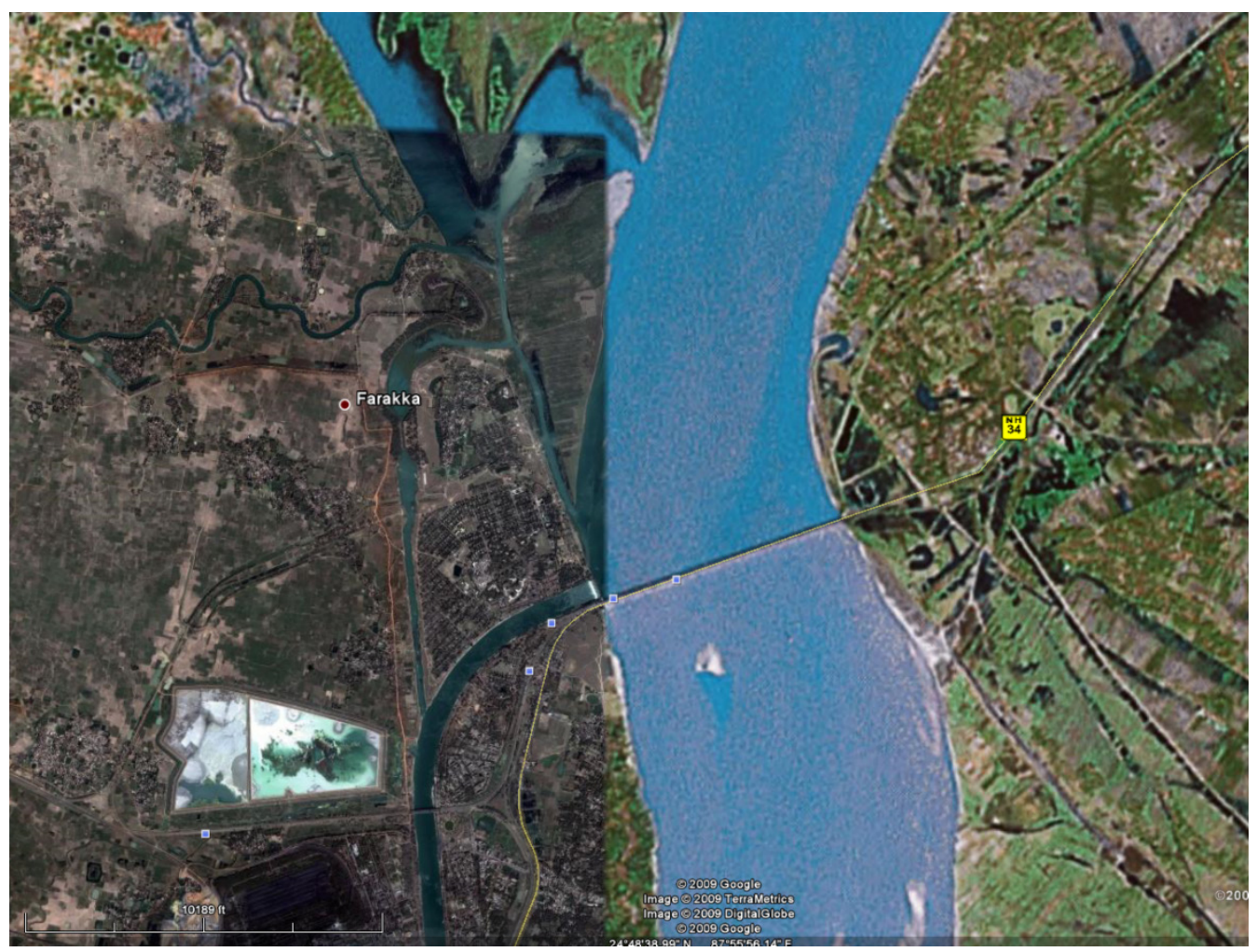

Figure 3. The Farakka Barrage across the Ganges and the seasonal Hooghly canal on the left that was made perennially navigable for building the nation's No. 1 waterway by pirating the downstream Bangladesh Ganges basin ecosystem's water, a glaring example of what is sport to the cat is death to the rat (Courtesy of Google Earth)

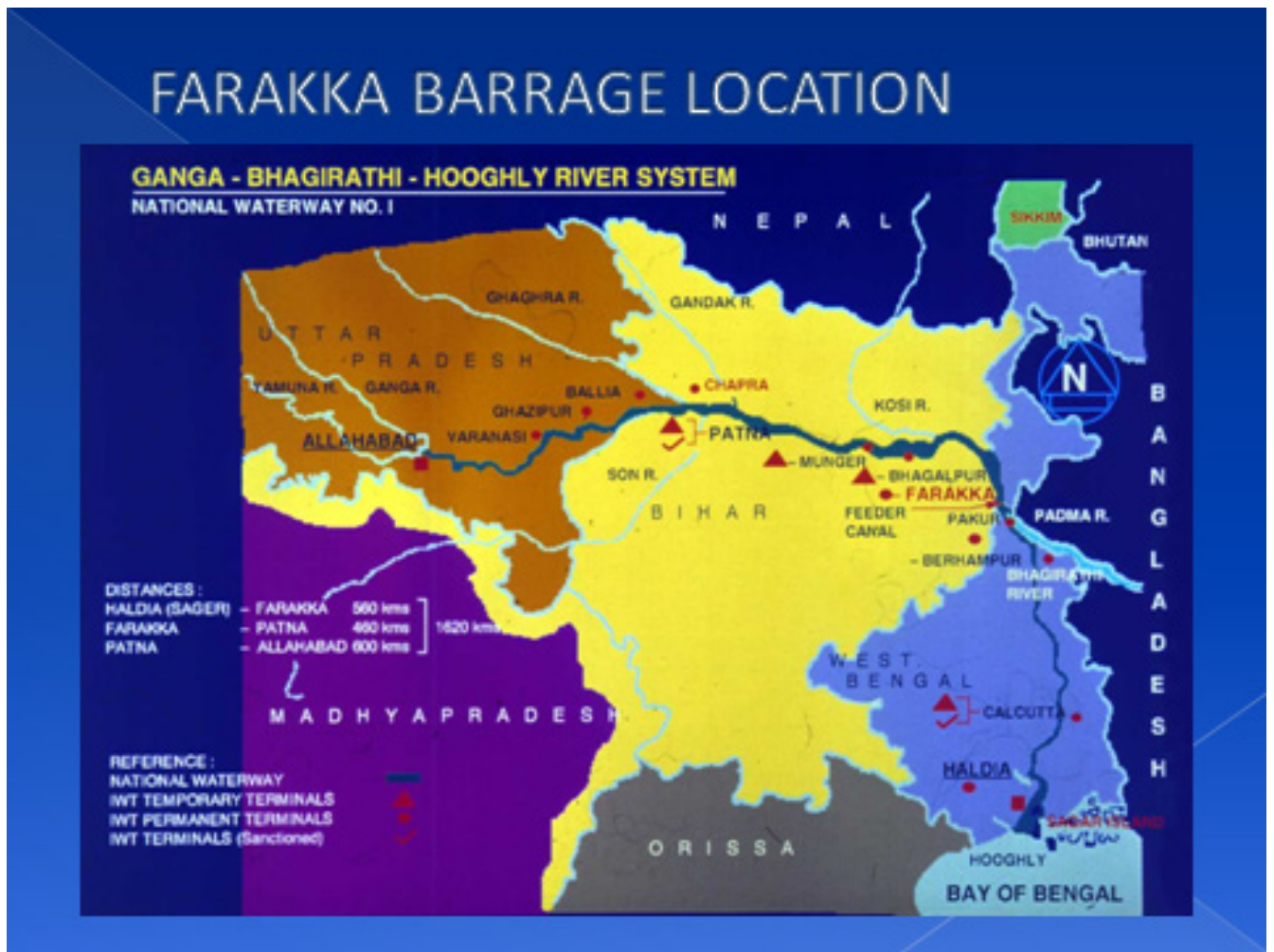

Figure 4. Nation's No. 1 waterways - from Haldia Ghat through the Hooghly River, Hooghly Canal, the Ganges up to Allahabad measuring $1620 \mathrm{~km}$ for inland cruise (http://india-wris.nrsc.gov.in/wrpinfo/index.php?title=National_Waterways-1). 


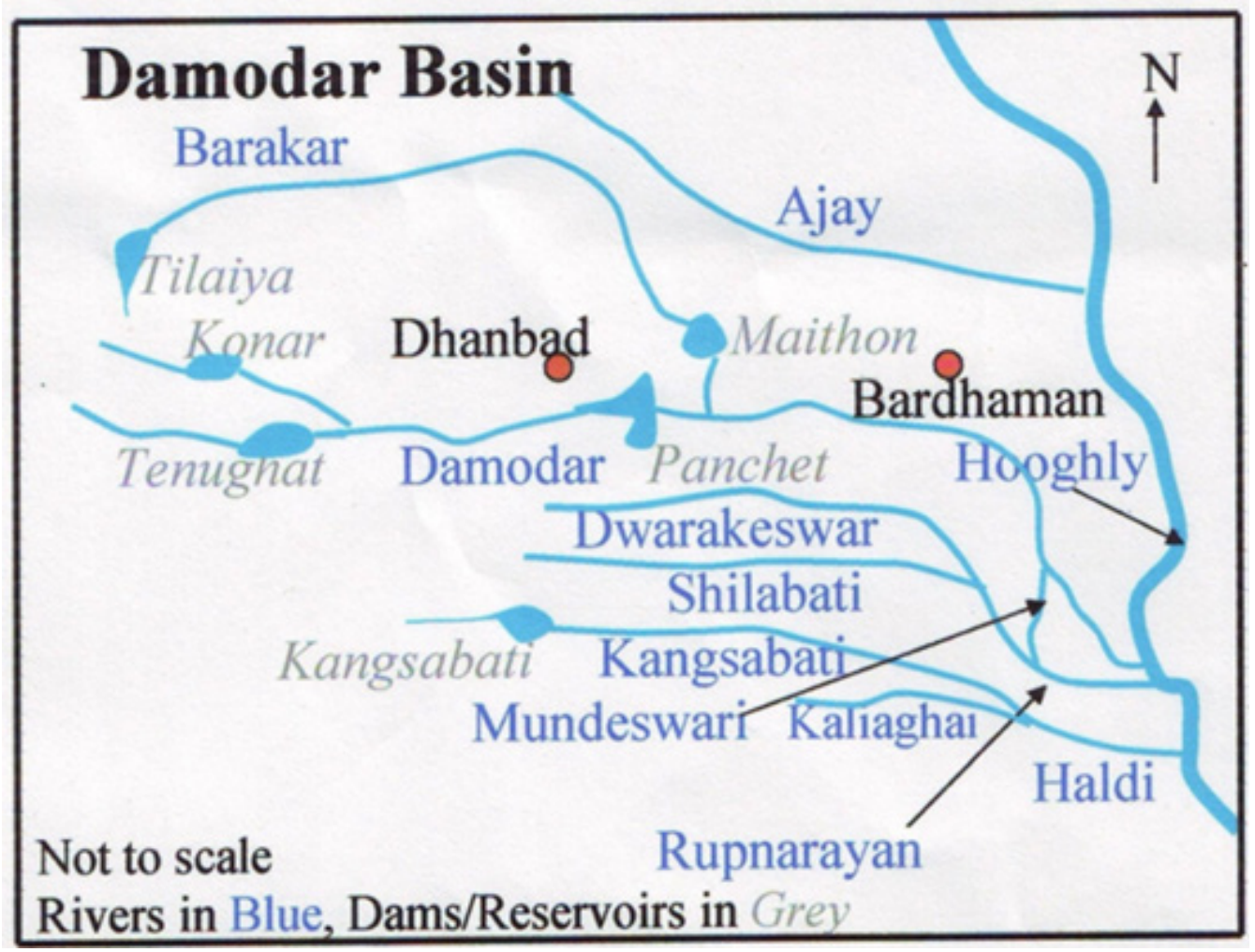

Figure 5. The dammed tributaries and sub-tributaries of the Hooghly River to create the fake water shortage for demanding water from Bangladesh Ganges ecosystem ((http://en.wikipedia.org/wiki/Damodar_River).

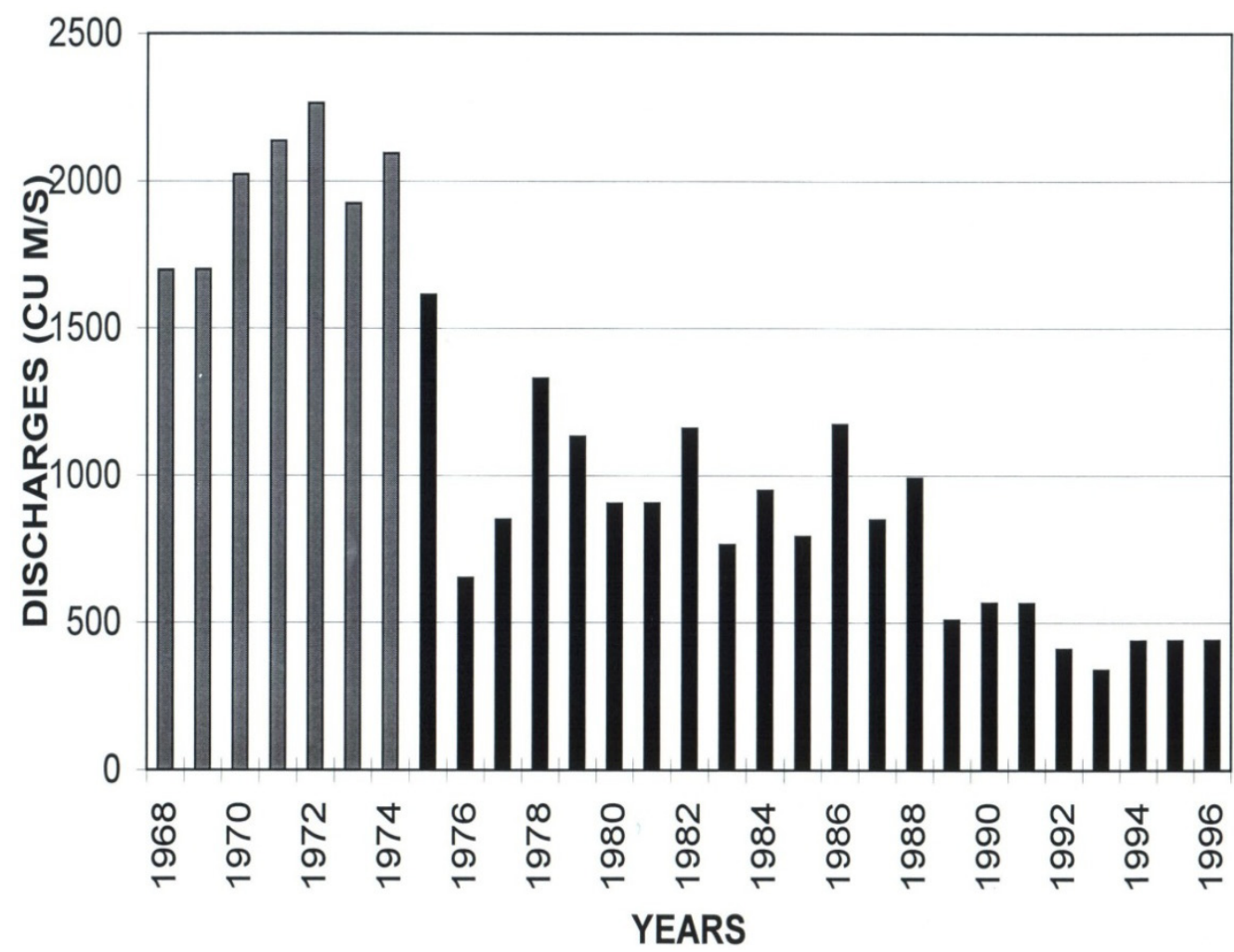

Figure 6. The Ganges ecosystem water piracy by India started in 1975 to establish the nation's number one waterways for the cruise line across India. (Hebblethwaite, 1997) 


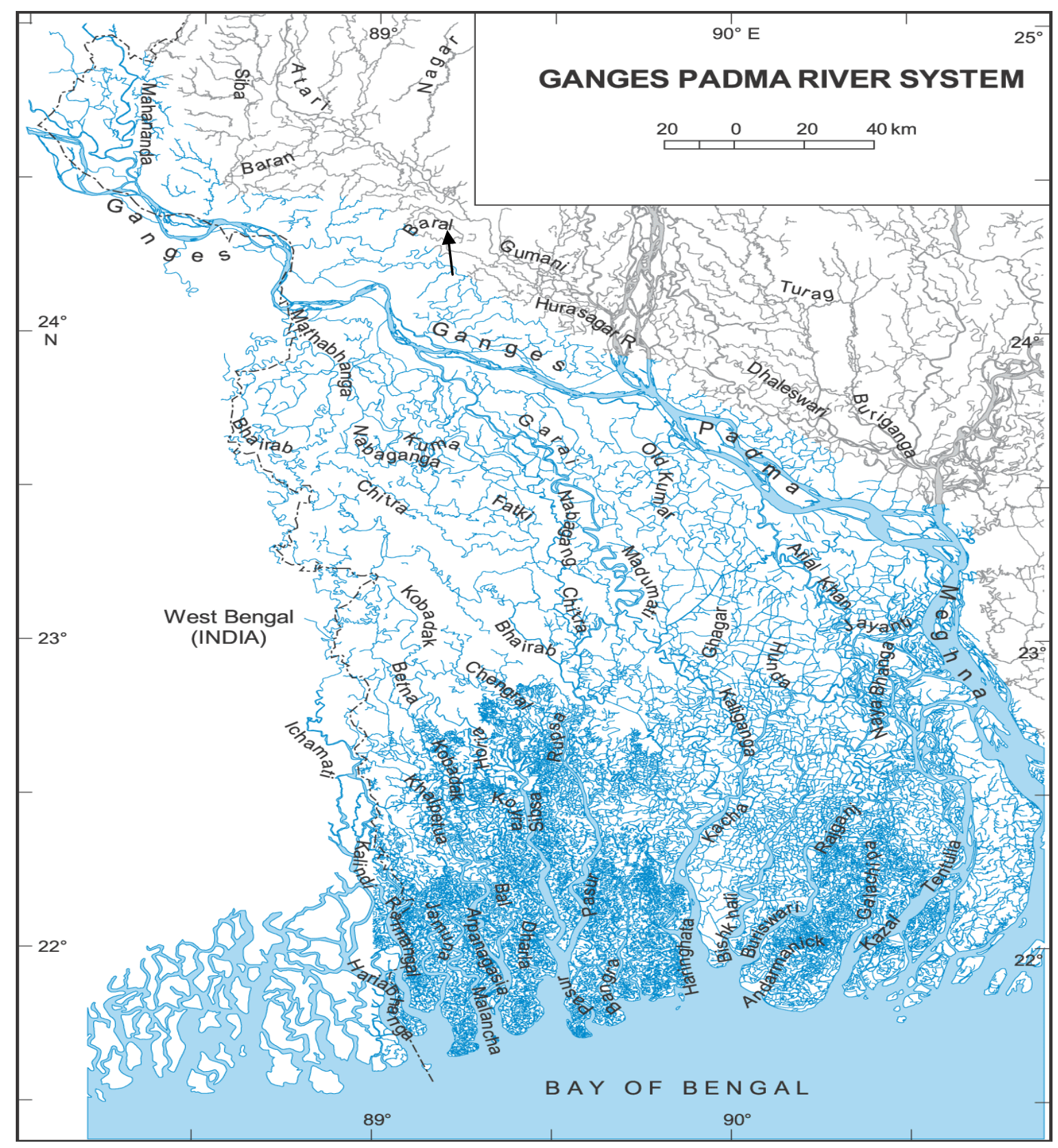

Figure 7. The Ganges basin in Bangladesh (http:www.dvc.gov.in/activitiesdamsbarrages.htm)

\section{Project Site}

The project site is marked by the upward arrow in Fig. 7. The site has been illustrated in Fig. 8. The Baral is the first and a primary distributary of the Ganges. The Musa Khan is a primary distributary of the Baral and, so, a secondary distributary of the Ganges (Fig. 8). The Musa Khan River is about twenty km long. The once-mighty and perennial river used to feed floodplains, ponds, ditches, and other low-lying areas on both sides of its bank covering more than $900 \mathrm{sq} \mathrm{km}$. The figure shows the basin area of the Musa Khan along with parts of the basins of the Baral, the Ganges, and the Atrai. The project area covers the Musa Khan basin and Baral basin. 


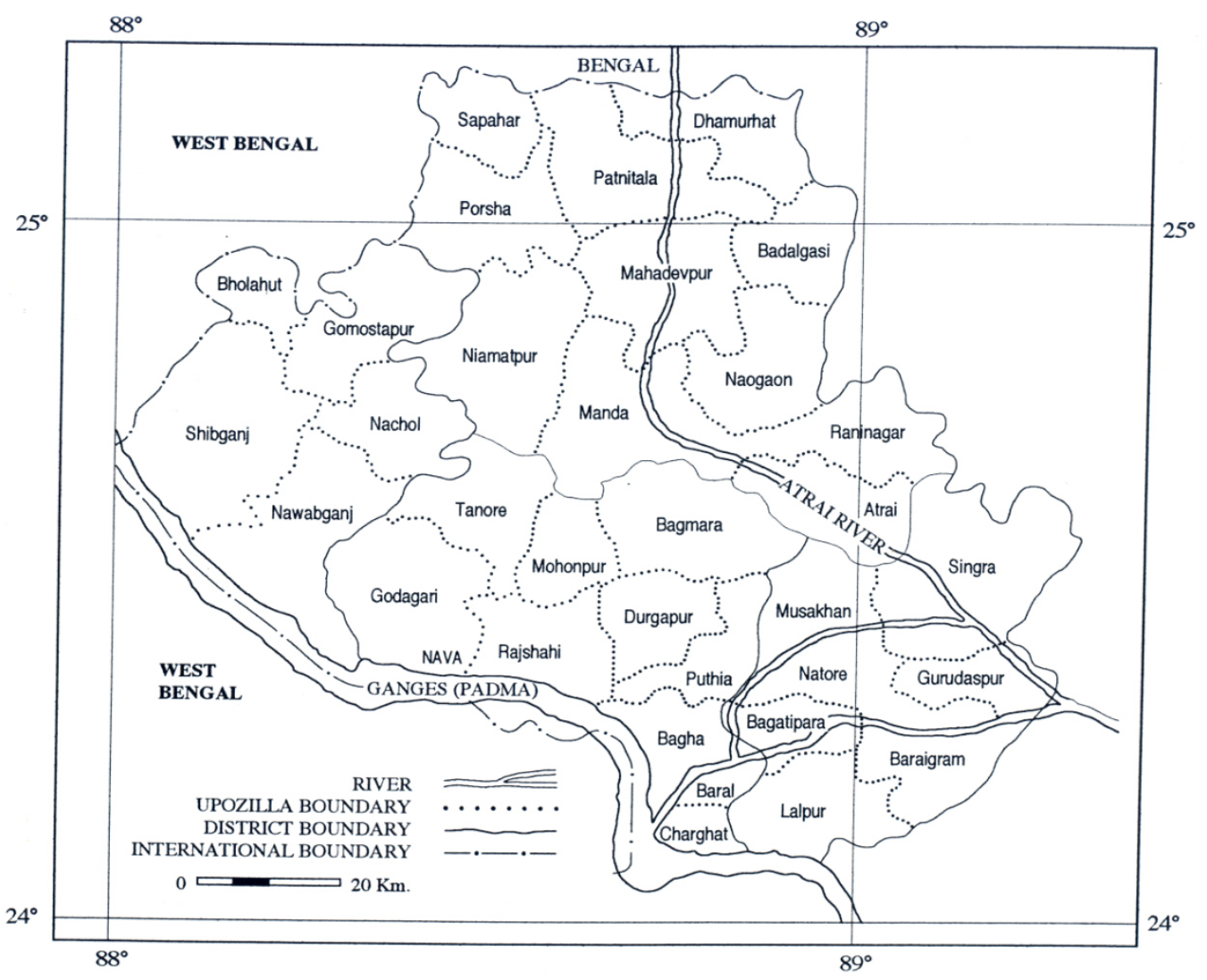

Figure 8. The project site. The Musa Khan River is not visible in Fig. 7, but it is in Fig. 8.

\section{Methodology}

The data of the discharge of the Ganges and its distributaries and the dam constructions on the international rives for water piracy were obtained from the Bangladesh Water Development Board and other government offices and organizations, and the eyewitness accounts (Sattar, 1996), and electronic and print media, . Field surveys were made to acquire water level and fish production data for the 175 floodplains, 100 ponds, and 100 ditches of varying sizes in the Musa Khan River basin and in the adjoining areas of the project site. The water level, fishing sites, and the fish catch data for each of the surface water source's were categorized as pre- and post-piracy era. These data were later further subdivided into the rainy or flood season and the summer season. Further, the distribution-free Kolmogorov-Smirnov (K-S) statistic (Hollander and Wolfe, 1999) was applied to compare data pertaining to different era. $X_{1} \ldots \ldots X_{m}$ and $Y_{1} \ldots \ldots Y_{n}$ are independent random samples for two different eras which could be pre- and post-piracy eras. For every real number $t$, the empirical distribution functions for $\mathrm{X}$ and $\mathrm{Y}$ defined as

$$
\mathrm{F}_{\mathrm{m}}(\mathrm{t})=(\text { number of sample } \mathrm{Xs} \leq \mathrm{t}) / \mathrm{m}
$$

and

$$
\mathrm{G}_{\mathrm{n}}(\mathrm{t})=(\text { number of sample } \mathrm{Ys} \leq \mathrm{t}) / \mathrm{n}
$$

are found. The two-sided two sample K-S statistic

$$
\begin{aligned}
& J=(m n / d) \quad \max \quad\left\{\left|F_{m}\left(Z_{(i)}\right)-G_{n}\left(Z_{(i)}\right)\right|\right\} \\
& \mathrm{i}=1 \ldots \mathrm{N}
\end{aligned}
$$

is calculated for the given $\mathrm{X}$ and $\mathrm{Y}$ where $\mathrm{d}$ is the greatest common factor of $\mathrm{m}$ and $\mathrm{n}$, and $\mathrm{N}=\mathrm{m}+\mathrm{n}$.

The $\mathrm{X}$ and $\mathrm{Y}$ probability distributions are not identical (the null hypothesis $\mathrm{H}_{\mathrm{o}}$ is not valid) at the $\alpha$ level of significance if $J \geq j_{\alpha}$, where $j_{\alpha}$ is chosen to make the type I error (error made by rejecting the null hypothesis when it is in fact true) probability equal to $\alpha$, also known as the level of significance of a test. The power of the statistical test increases as the level of significance $\alpha$ increases. Larger values of $\alpha$ increase the power along with the increased probability of a type I error. The less stringent value of $\alpha$ is made, the more likely the rejection of the null hypothesis when it is false. Tabulated values of $j_{\alpha}$ are 
available in such a way that there are at least as many $\mathrm{Y}$ observations as there are $\mathrm{X}$ observations; i. e. the labeling of X and $\mathrm{Y}$ is done in such a way to satisfy $\mathrm{m} \leq \mathrm{n}$. In the large sample approximation, based on the asymptotic distribution of

$$
\mathrm{J}^{*}=\mathrm{Jd} /(\mathrm{mnN})^{1 / 2}
$$

the null hypothesis Ho (corresponding to identical $\mathrm{X}$ and $\mathrm{Y}$ probability distributions) is rejected if $\mathrm{J}^{*} \geq \mathrm{q}^{*} \alpha$, where $\mathrm{Q}\left(\mathrm{q}^{*} \alpha\right)=$ $\alpha$

\section{Results}

\subsection{Depletion of Surface Water Resources}

The water resources included rivers, streams, canals, floodplains, ponds, ditches, and low-lying areas. Their water retention time would be from about six months to a year with fluctuating depths..

\subsubsection{Obstructed Ganges Flow}

The year-wise Ganges discharge is plotted in Fig. 6. The post- piracy is about $60 \%$ of the pre-piracy value. A few peaks in the post-piracy flow era are due to the few shorter-term Bangladesh's forced agreements to India's water piracy under extreme cornerin in between longer-term upstream unilateral water piracy by India. An application of K-S statistic with $\mathrm{m}=$ 7 for pre-barrage $\mathrm{X}$ observations and $\mathrm{n}=22$ for post-barrage $\mathrm{Y}$ observations, yields $\mathrm{J}^{*}=2.4$ and $\mathrm{Q}\left(\mathrm{J}^{*}\right)=0.0$. Thus the smallest significant level to reject the null hypothesis corresponding to identical $\mathrm{X}$ and $\mathrm{Y}$ probability distributions is zero. For about three decades, the project site has not received the Ganges water at all. The condition of the Ganges is shown in Fig. 9. The photograph on the left reflects the Ganges condition in the mid-nineties near the Hardinge Bridge located about $174 \mathrm{~km}$ downstream from the Indo-Bangladesh border. The right side photograph is a beginning of 2012 picture of the Ganges beside the largest riparian city Rajshahi in Bangladesh.

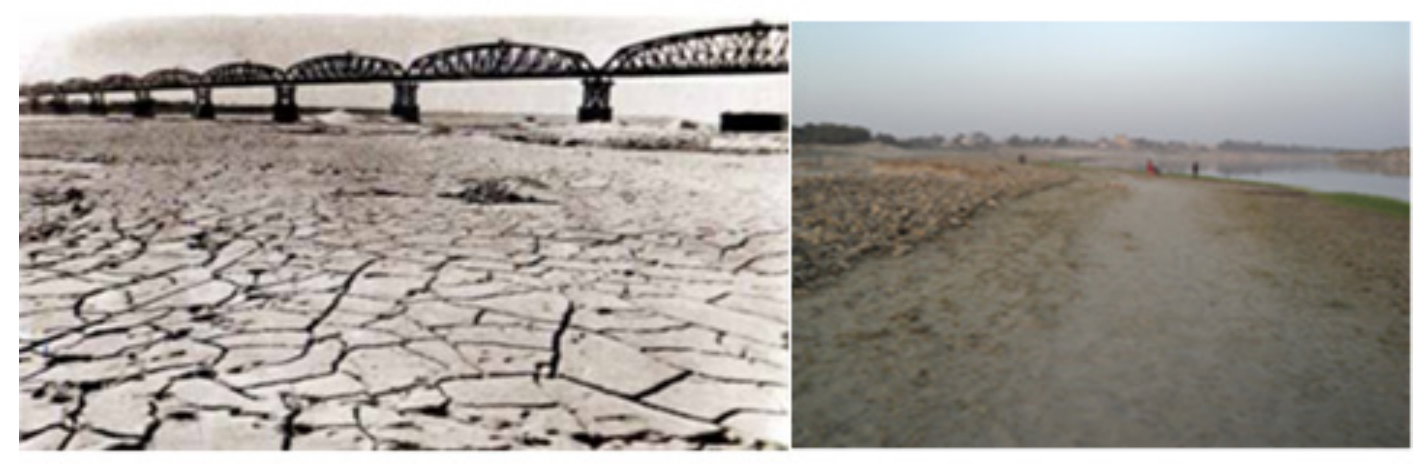

Figure 9. The condition of the Ganges in the mid-nineties (courtesy of Salahuddin) near the Hardinge Bridge (left side inset) and in the beginning of 2012 near the city of Rajshahi (right side inset)

\subsubsection{Dry Primary Distributary}

The Baral River (Fig. 10), the once-perennial primary distributary of the Ganges that stretches about $80 \mathrm{~km}$ has become a seasonal stream. Following the decreased flow in the Ganges, a huge shoal of about $1 \times 1 / 2 \mathrm{~km}^{2}$ has formed at the mouth of the Baral River. At places, it has dry beds. The river has been shrunken in depth and width by more than a factor of two. In the pre-piracy days, the river used to discharge, on the average, at least $2000 \mathrm{~m}^{3} / \mathrm{s}$ for at least five months (July - November) annually. The live Baral was the lifeblood of its and Musa Khan basin ecosystem. Its dry course has brought a radical change in the ecosystem.
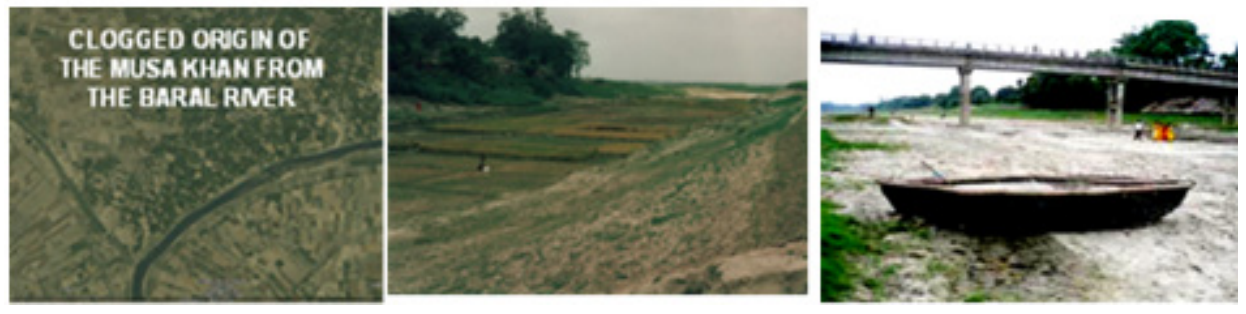

Figure 10. The dead Baral River goes to the right and the dead Musa Khan River branches off to the left (left side inset). The dry bed of the Baral where it originates from the Ganges (middle inset). The dry bed of the Musa Khan at its course (right side inset, courtesy of the Amar Desh). 

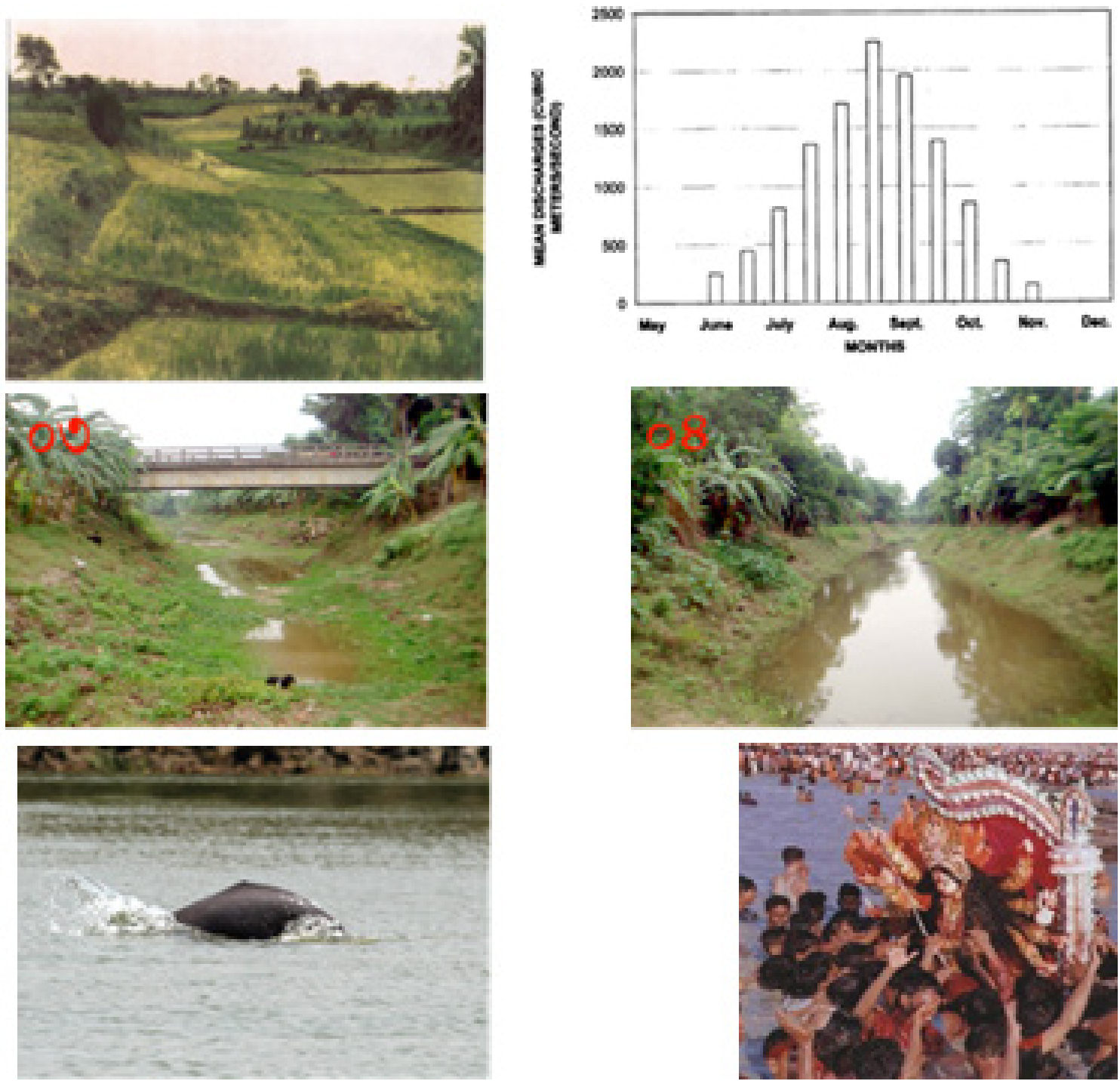

Figure 11. The dry bed of the Musa Khan where it originates from Baral (top left). The dead Musa Khan's pre-piracy period hydrograph (top right). The Musa Khan's current condition (the middle row). Sportive dolphins would be fill the Musa Khan (bottom left, the picture is taken from elsewhere just to show what has been lost in the ecosystem). The minority Hindus would celebrate their Durga Puja in the Musa Khan water as shown here (bottom right). http://www.bing.com/images/search?q=Images + of + Durga+Immersion+in+Bangladesh\&qpvt=Images + of + Durga + Immersion+in+Bangladesh\&FORM=IG $\mathrm{RE}$ the picture has been imported from another source just to show the pomp and grandeur of the festival the Musa Khan basin used to have).

\subsubsection{Dead Secondary Distributary}

The secondary distributary Musa Khan (Figs. 11 and 12) remains dry all the year. It used to discharge annually, at least, 1000 cubic meter per second. Its original size at the point of origin is hard to determine because of leveling off of the bank with the shoal formed at the mouth. All the aquatics and the amphibians that lived in the water pre-piracy period in a stretch of about $20000 \mathrm{~m}$ long, $12 \mathrm{~m}$ wide, and $2 \mathrm{~m}$ deep water course during November through June and in about $20000 \mathrm{~m}$ long, 100 $\mathrm{m}$ wide, and $10 \mathrm{~m}$ deep water course during July through November are gone. The guest creature Gangetic dolphins (Fig. 11) would be present in abundance during July through November. The Musa Khan used to maintain rich wetland ecosystem (a sample of what has been shown above in Fig. 1) in about $900 \mathrm{sq} \mathrm{km}$ of its basin. At some places in its course, people built dykes at some distance apart to hold run-off water to meet their washing needs for some time. One such location is shown in Fig. 13 below. Upstream human action does not hesitate to desertify the downstream riparian nation. 

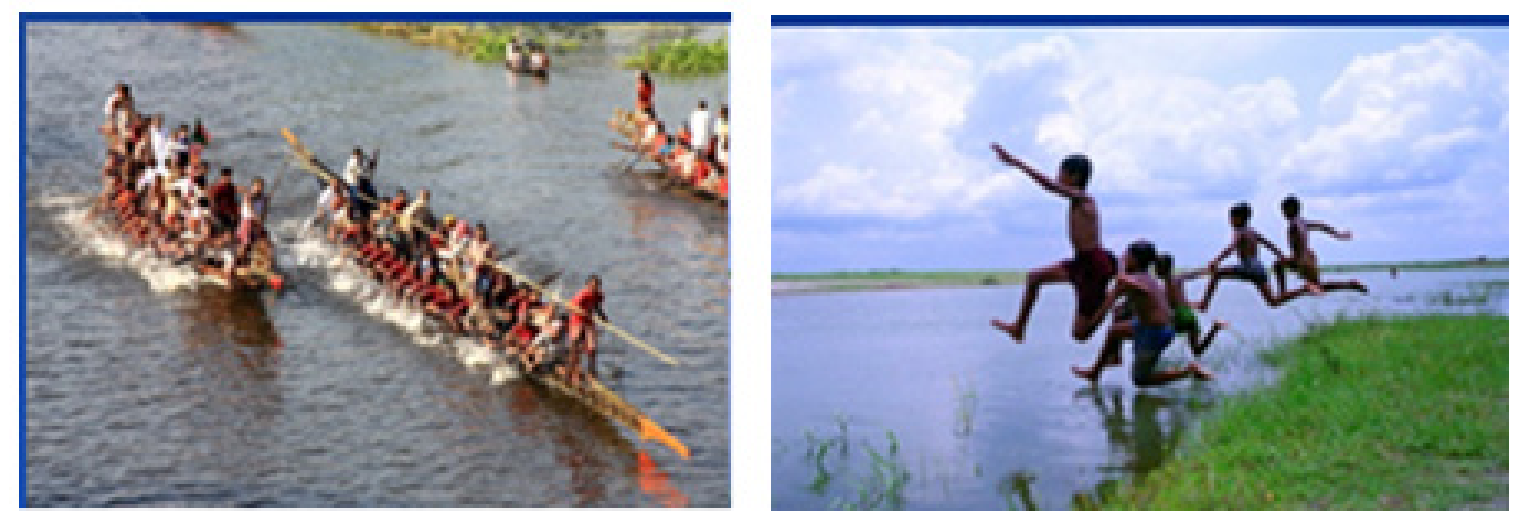

Figure 12. Such scenes of boating racing (during the Durga Puja celebration) and sportive boys would be common in the Musa Khan River and in the water bodies fed by the Musa Khan River in the pre-piracy period (Pictures are taken from elsewhere of the country as no pre-piracy era picture exists).

\subsubsection{Extinct Tertiary Distributary}

The Hosa River (lifet side picture in Fig. 13) is a distributary of the Musa Khan. The extinct Hosa River was turned into a canal for carrying water to interior floodplains and to its midway parts. The British rulers in India used this water route commercially for the neel (meaning the blue) business. The British colonial power would force the farmers to cultivate neel plants. They used to maintain an office (brick-built middle picture in Fig. 13) as well as a neel reting facility (right side dome structure picture in Fig. 13). The Hosa River died because of the upstream water piracy from the Ganges.
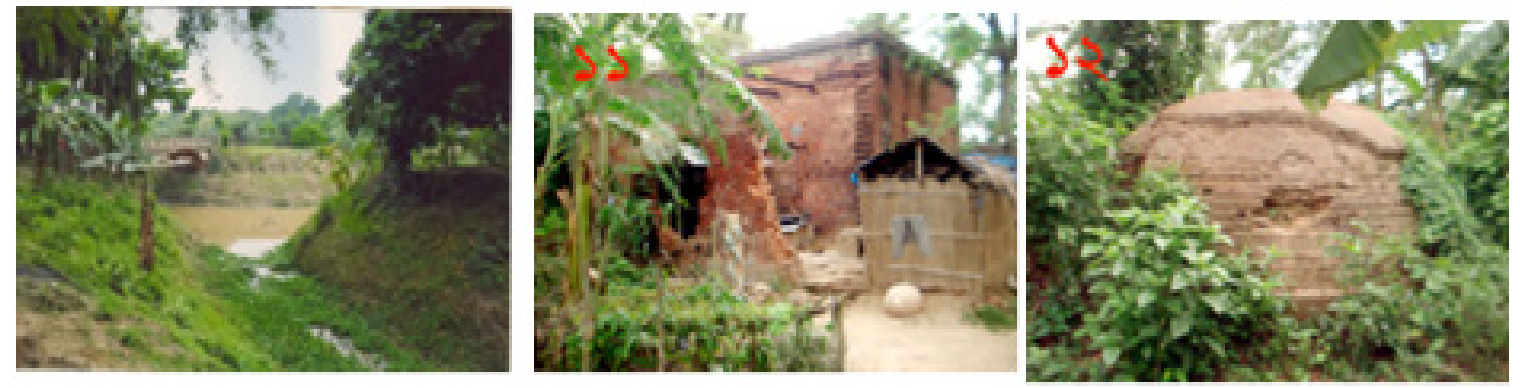

Figure 13. The Hosa River, a distributary of the Musa Khan, turned into a canal after excavation (left), the Neel Kuthi by the river (middle), and the neel-retting house ( right). People built earthen dykes on the Musa Khan bed to hold some rain water at the mouth of what is now the Hosa Canal.

\subsubsection{Floodplains}

In the wetland ecosystem, floodplains were the abundantly breeding and raising grounds of the Gangetic fishes discussed later. Floodplains were also the natural wells for groundwater recharging and store houses for summertime heat collection and wintertime release. These served as the jute-retting facility, too. Fig. 14 compares the floodplain water retention depths of the mid-nineties with that of the pre-piracy period. An application of K-S statistic shows $\mathrm{J}^{*}=1.96$ and $\mathrm{Q}\left(\mathrm{J}^{*}\right)=0.0009$. Thus the smallest significant level at which we can reject the null hypothesis corresponding to the identical pre-barrage $\mathrm{X}$ and post-barrage Y probability distributions of floodplain water retention is 0.0009 .

Floodplain water levels pertaining to the pre-piracy period and the mid-nineties are presented in Fig. 15. An application of K-S statistic yields $\mathrm{J}^{*}=0.9805$ and $\mathrm{Q}\left(\mathrm{J}^{*}\right)=0.2921$. Thus the smallest significant level to reject the null hypothesis corresponding to identical pre-barrage $\mathrm{X}$ and post-barrage $\mathrm{Y}$ probability distributions is 0.2921 . The water level dropped to about $50 \%$ of its pre-piracy value in the middle of the last century. Consecutive four years of decreasing rainfall beginning from 2006 dried up all surface water bodies in 2010. The few ponds that had some water was from extraction of groundwater using deep tube-wells.

Fishing time in flood plains would be July through March. Public fishing in large and deep floodplains would take place toward the end of this period. Fishing in small and shallow floodplains would end in November. The use of fishing gears were dependent on the types, sizes, and shapes of fishes, shallow or deep water bodies, flowing or stagnant water bodies, bottom-feeders or surface-feeders, day or night fishing, scattered or wide area fishing, early, deep, later, or post-monsoon season. Some of the fishing scenes are depicted in Figs. 16 and 17 using pictures taken from fishing in other parts of the country. 


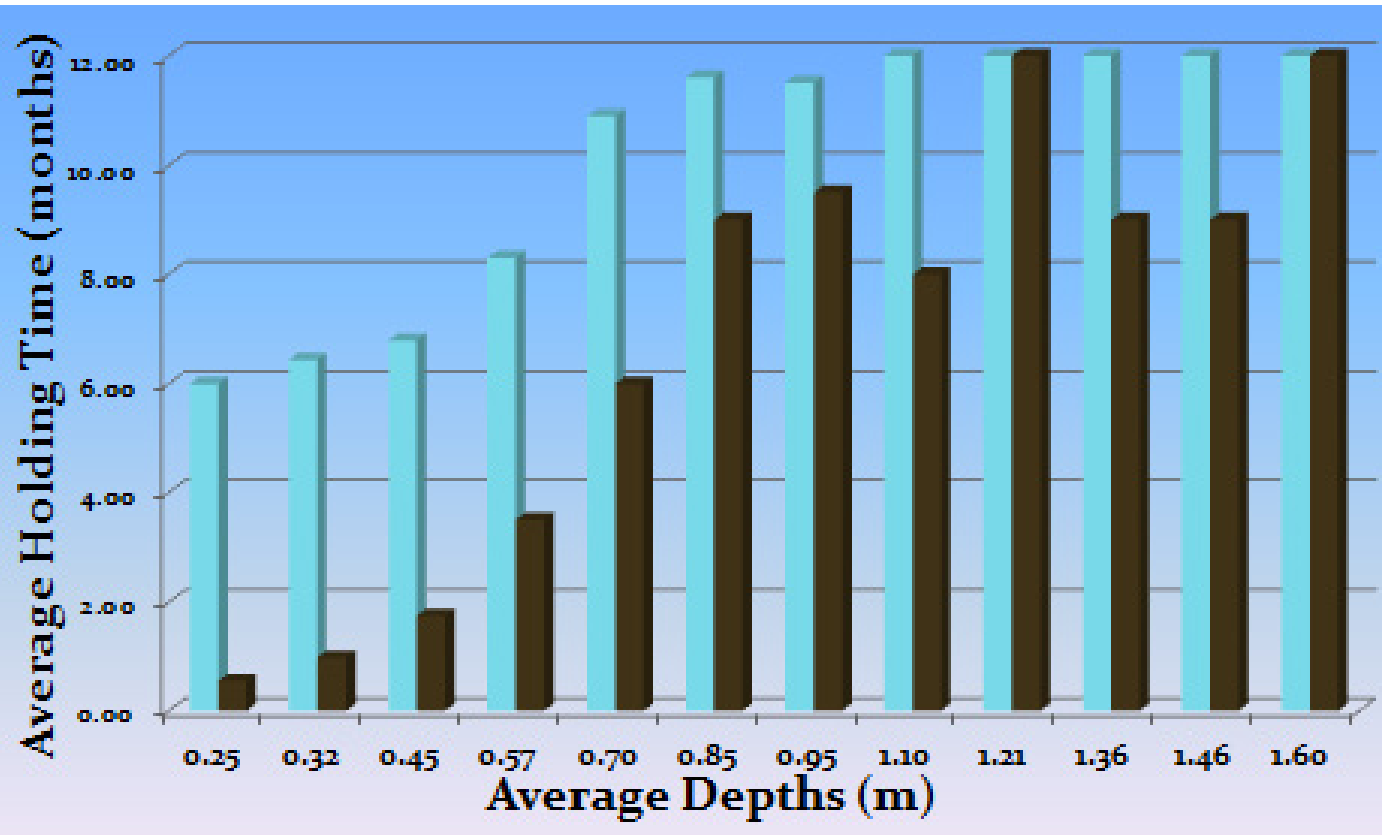

Figure 14. Floodplain water retention depths of the nineties is compared with the pre-piracy period water retention depths.

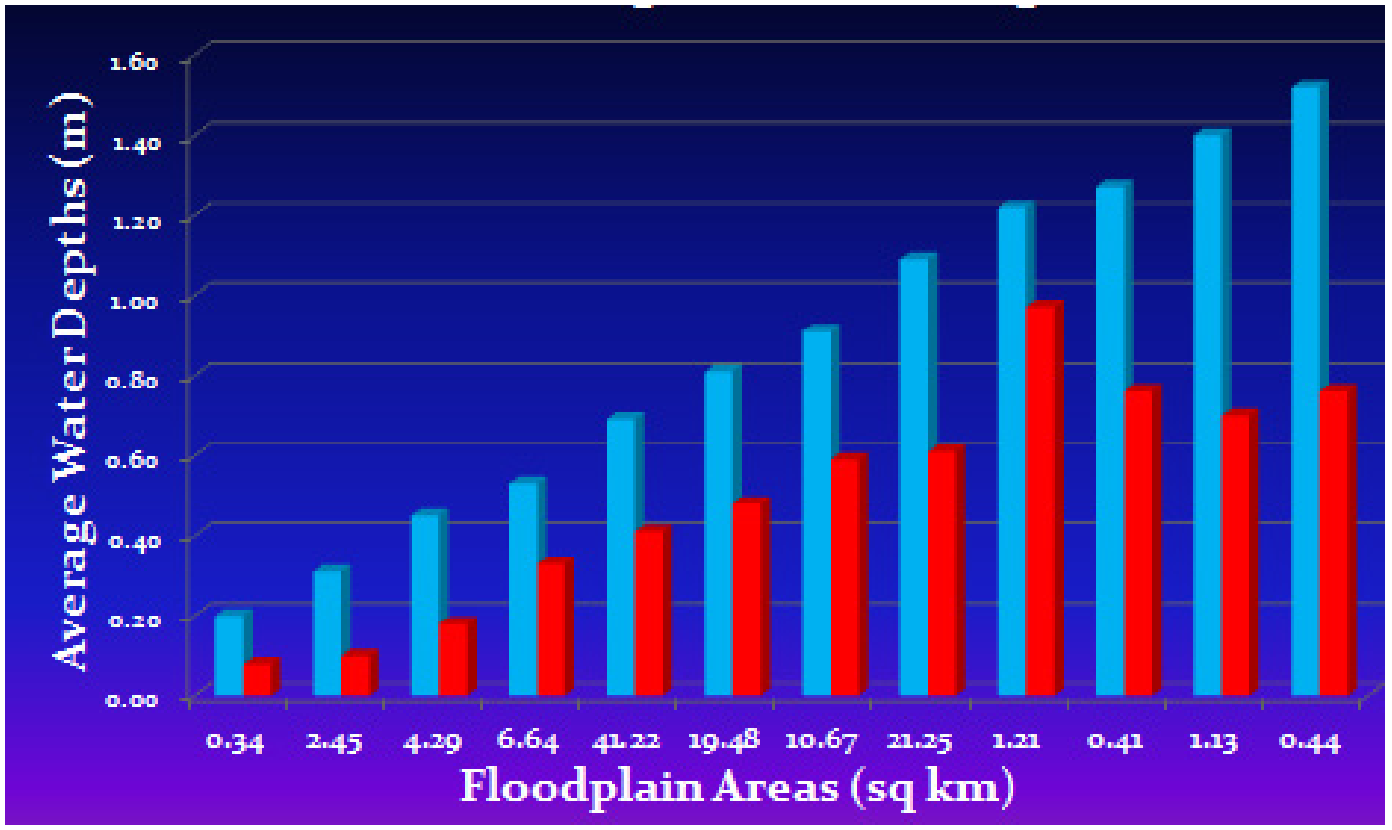

Figure 15. Floodplain water depths of the nineties compared with the pre-piracy period.
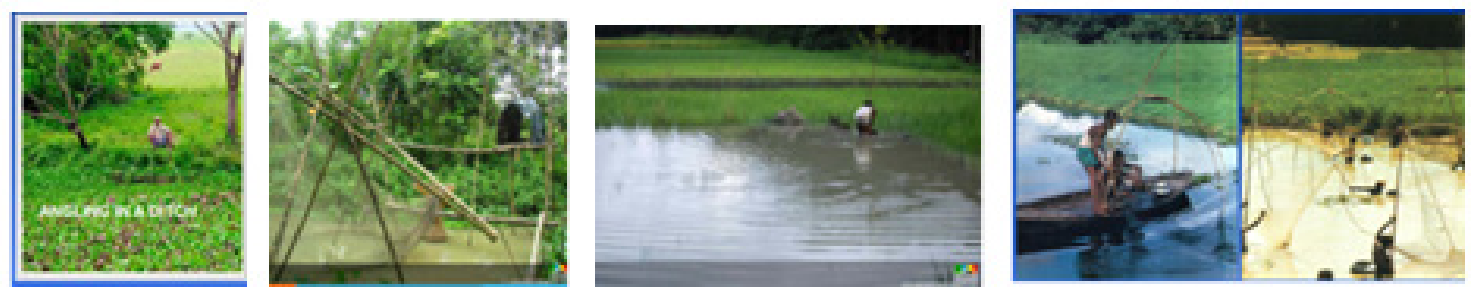

Figure 16. Angling in a ditch full of water-hyacinth (left side inset) and fishing by net ( $2^{\text {nd }}$ inset from the left).

http://www.bing.com/images/search?q=Fishing+Nets+in+Bangladesh\&qpvt=Fishing+Nets+in+Bangladesh\&FORM=IGRE\#view=detail\&id=439444E31 F1E72811040C827E8DE55C40B7DDC88\&selectedIndex $=32$; rice field fishing in shallow floodplains using gears made of bamboo strips $\left(3^{\text {rd }}\right.$ inset from the left) (www.panoramabangladesh.com); deep floodplain fishing using nets and boats ( $4^{\text {th }}$ and the $5^{\text {th }}$ insets from the left .anonymous). 

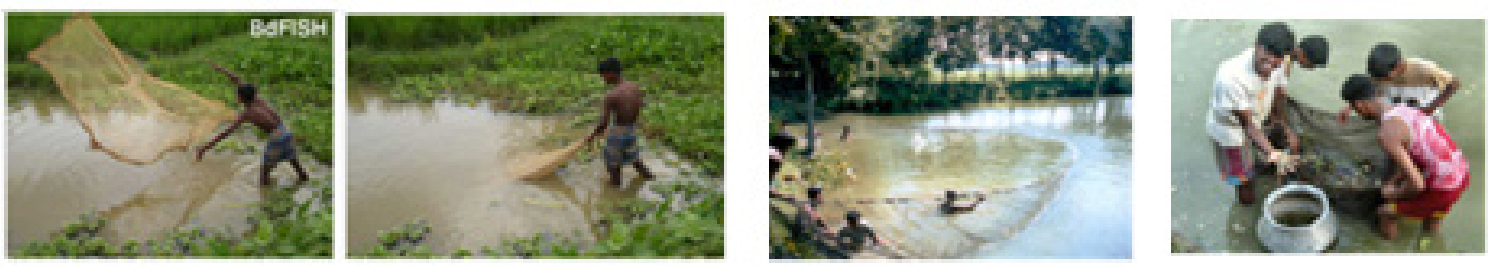

Figure 17. Fishing in a ditch by tore jal or throw net; fishing in a larger and wider water body than a ditch using mopping net of ber jal; shallow water fishing by nets or porous clothes .

http://www.bing.com/images/search?q=Fishing+Nets+in+Bangladesh\&qpvt=Fishing+Nets+in+Bangladesh\&FORM=IGRE\#view=detail\&id=150B27934 31AD9E27734944C7DB092F3D0488ABE\&selectedIndex=6; http://en.bdfish.org/2009/11/fresh-water-prawn-farming-northern-bangladesh/. These nets were used in fishing in ponds shown Fig. 20 belowe in the pre-piracy days.

Unfortunately, this wetland ecosystem has turned into a dry land one as shown in Fig. 18 in which massive groundwater is being used in the absence of the Ganges water and adequate rainfall. Scanty and irregular rainfall is alone is not enough to sustain the wetland ecosystem.

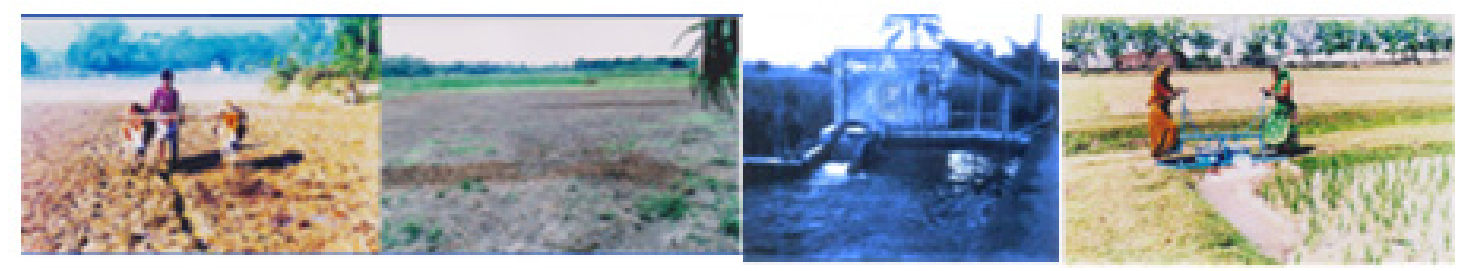

Figure 18. Post-piracy period current scenes of dry floodplains (top left and right), and massive groundwater withdrawals (bottom left and right) to irrigate lands in the absence of surface water contribution from the Ganges and adequate rainfalls.

\subsubsection{Canals}

Like rivers, canals were sources of running water from the river. After the flood season, they would have more than a meter-deep stagnant water that would dry out at the of winter months. Kilometers-long canals of average cross sections of about $4 \mathrm{~m} \mathrm{x} 3 \mathrm{~m}$ would link rivers with interior floodplains (Fig. 19). They would have water flowing during July through November. Toward the end of the flood season as the river level would drop, farmers would drain floodplain water to the river for getting the land ready for winter crops. These are now dry, squeezed, and clogged. The Musa Khan had a dozens of canals to discharge water in the interior floodplains, ponds, ditches, and other low lands. These canals would discharge trillions of gallons of water to the interior floodplains for almost six months annually. For decades, these areas are without the supply of that water. These are now wasting land in a land-scarce country. At every few hundred meters, people would put straw fence across the canals with slots for placing fishing gears.

River, floodplain, and pond fishes would be available in canals. Large size fishes would be available in the canals when the Ganges flood water would flow in them. Brisk fishing time would start from August and last till November. Abundant small fishes that resulted from breeding in the flood season would be available in canals toward the end of the season.

\subsubsection{Ponds}

Villages by the riverside never had a real pond in the pre-piracy days when the number of ponds in interior villages was, on an average, 10 per village. Riverside villages had large size ditches. Parallel to the Musa Khan River bank, there are about 40 villages within two-village spaces from the river side. Ponds were places for open bathing, swimming, and fishing by angling and with nets for the villagers. Their average size would be around $50 \mathrm{~m} \times 30 \mathrm{~m} \times 10 \mathrm{~m}$. A few ponds would be collectively owned by the villagers. Family pond owners would raise spawns sold to them by professional fishermen. Except for a few species of small fishes, ponds were not breeding grounds for fishes like other surface water resources. These surface water bodies were year-round fishing places. These would be filled by overland flows and the Ganges water. Many ponds would be leased to professional fishermen. Some ponds are pictured in Fig. 20.

As to the pond water depth, it is found that the post-piracy monsoon season water depth in the mid-nineties is at the level of the pre-piracy dry season water depth in the ponds (Fig. 21). An application of K-S statistics for the monsoon season pond water depth yields $\mathrm{J}^{*}=1.25$ and $\mathrm{Q}\left(\mathrm{J}^{*}\right)=0.0879$, the lowest significant level to reject the null hypothesis corresponding to the identical pre- and post-barrage water level probabilities.

An application of the K-S statistic to the dry season pre- and post-barrage pond water levels (Fig. 22) yields $\mathrm{J}^{*}=1.5$ and $\mathrm{Q}\left(\mathrm{J}^{*}\right)=0.0222$, the lowest significant level to reject the null hypothesis corresponding to the identical pre- and post-barrage water level probabilities.

Few pond-owners use groundwater to raise fish in the post-barrage era. An application of the K-S statistic to the pre- and 
post-barrage pond fish production yields $\mathrm{J}^{*}=1.428$ and $\mathrm{Q}\left(\mathrm{J}^{*}\right)=0.0335$, the lowest significant level to reject the null hypothesis of the identical pre- and post-barrage pond fish production probabilities.
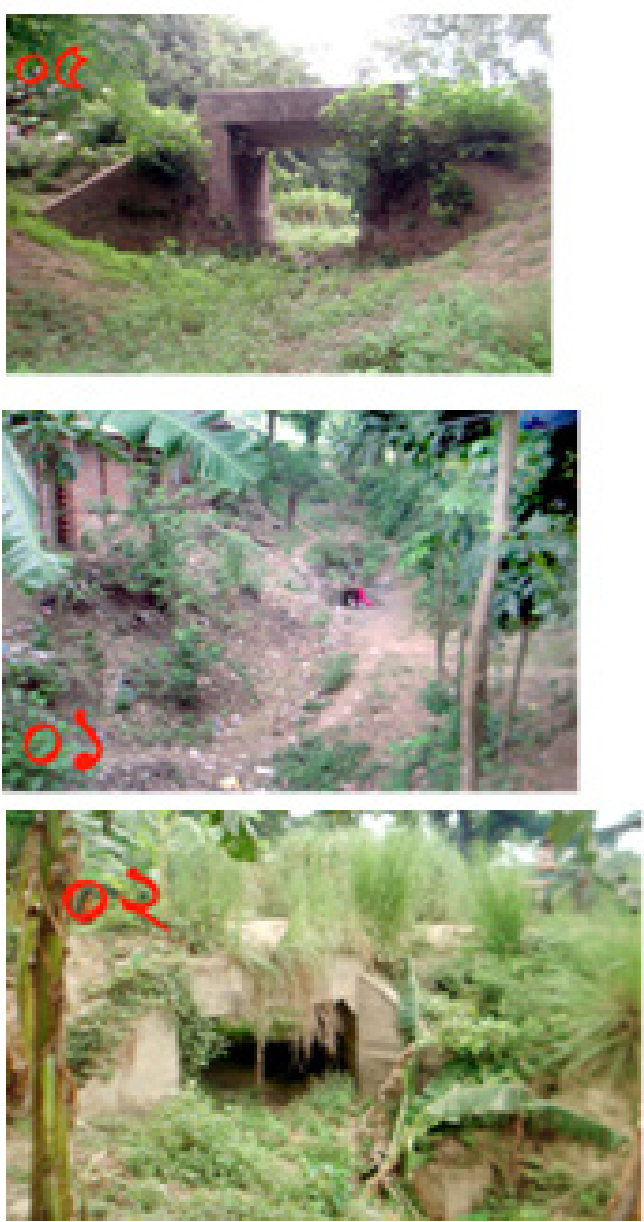
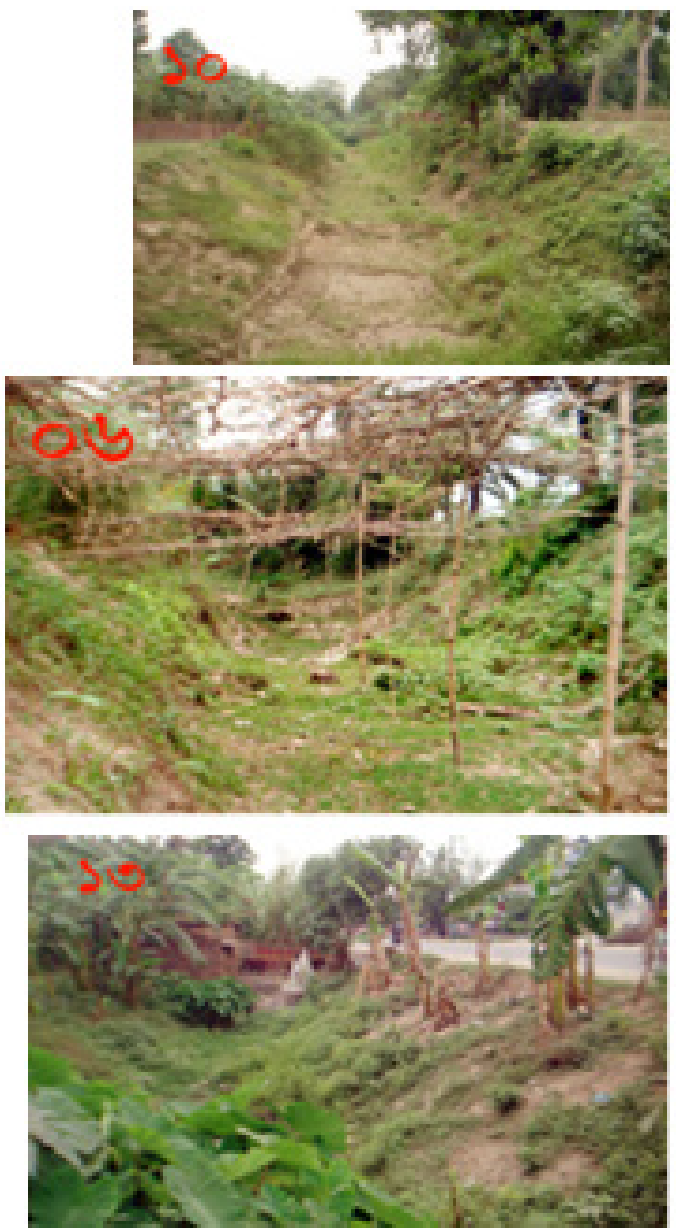

Figure 19. Abandoned canals from the Musa Khan River in the post-piracy period. These are scenes of invaluable land wastage in a land-scarce country.

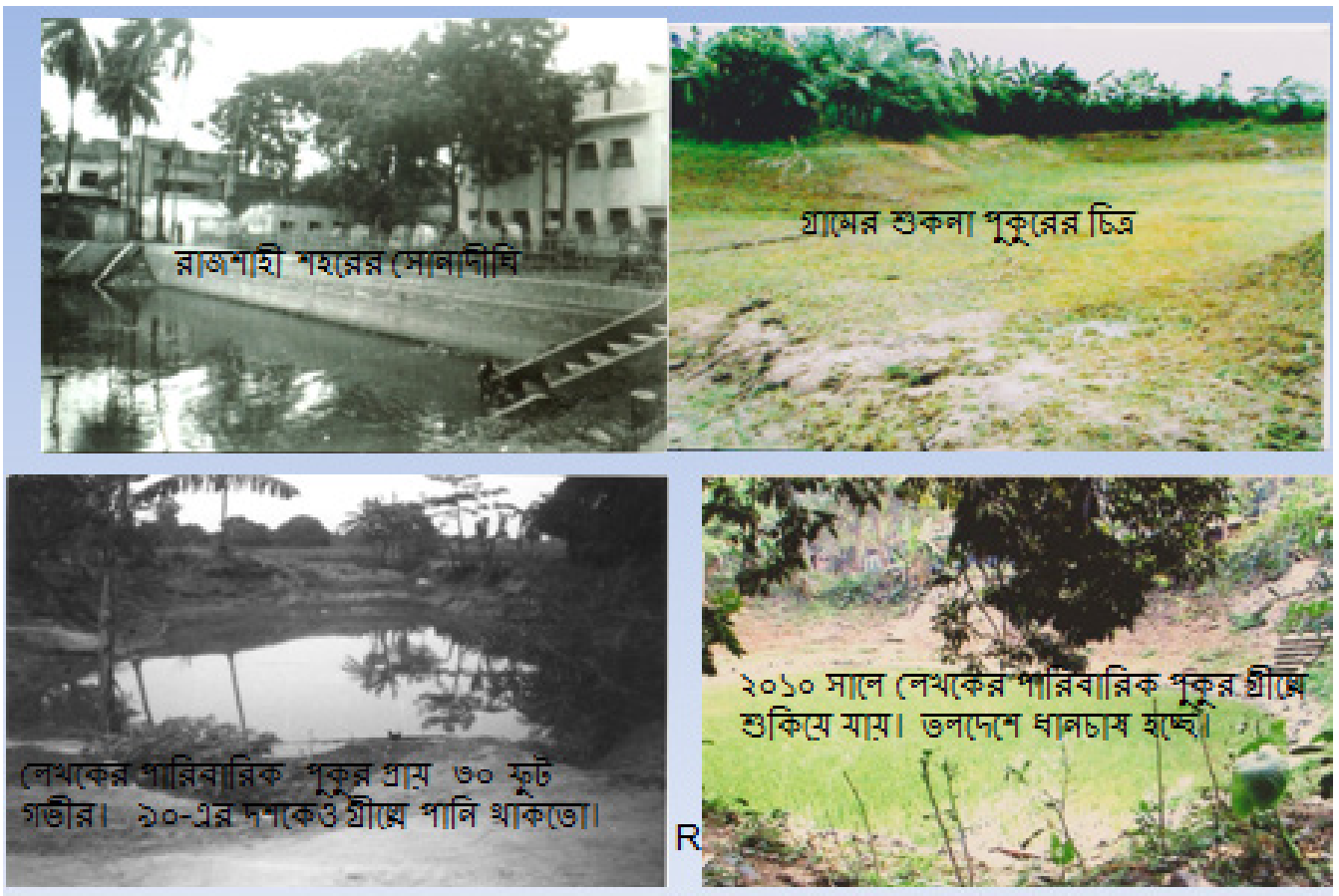

Figure 20. The historic pond turned shallow in the Rajshahi City beside the Ganges (top left). A rural pond turned dry (top right). The author's family pond live in the 1990s (bottom left). The author's family pond turned dry in 2010 and rice planted at the bed (bottom right). 


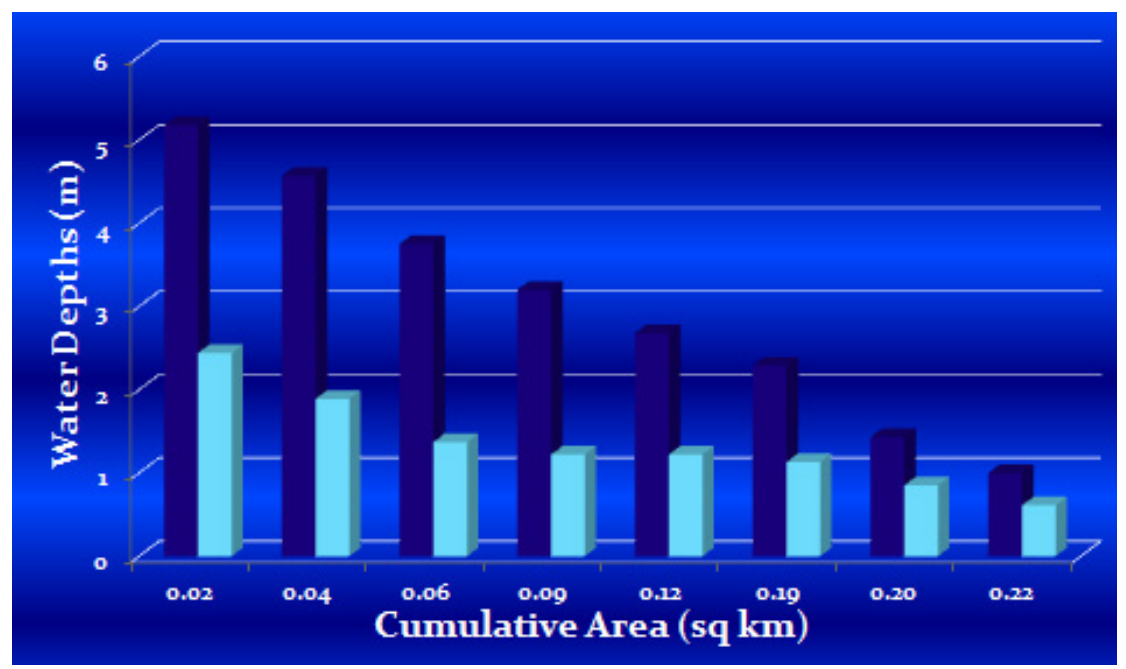

Figure 21. Pond water depths in the rainy and dry season during the pre-piracy period. The larger bars represent the rainy season and the shorter bars the dry season water depths.

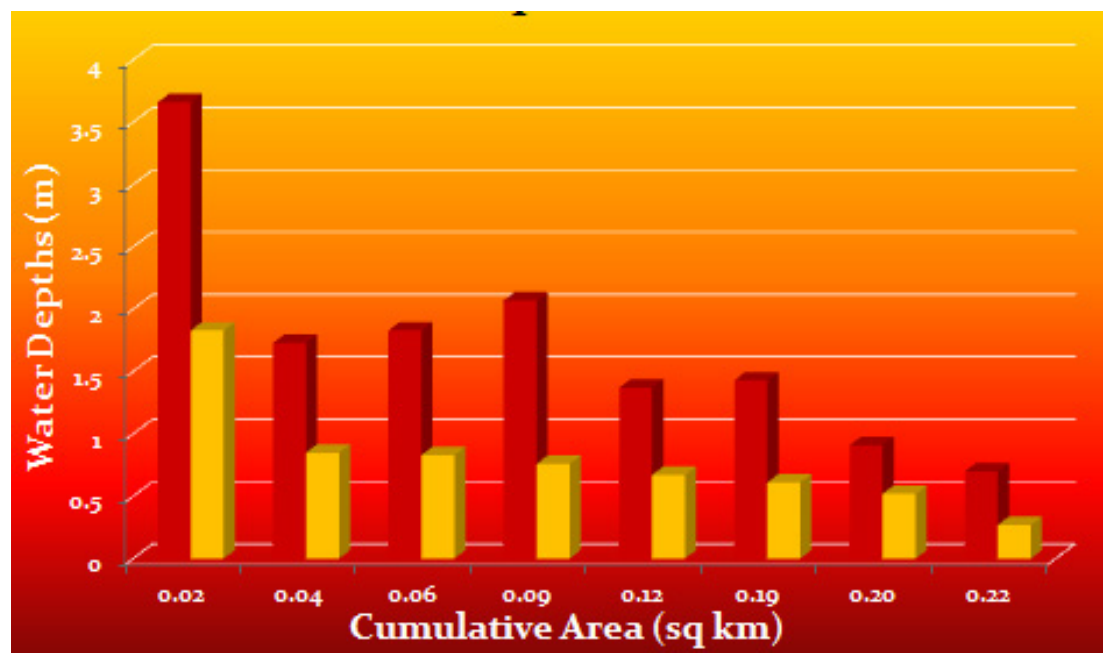

Figure 22. Post-piracy period pond water depths in the mid-nineties. Larger bars represent the rainy season and the shorter bars the dry season water depths. The deepest pond became dry following the drought in 2010.

\subsubsection{Ditches}

In the Ganges delta, ditches were the results of digging earth for raising rural house bases. These are shallower and smaller in size than ponds. They would hold water during the wet season (Fig. 23). In the rural area, every family had a ditch. A family ditch would provide water for washing, jute-retting, duck-raising, fish production, groundwater recharging, and for storing heat in summer for release in winter not to let fall winter temperature. Further, it would provide a habitat for migratory birds and countless aquatics. After the season's first rainfall, frogs from their habitat in the ditch would start chorus and would build overnight hundreds of nests (rightmost picture in Fig. 23) in a tree beside the ditch. These amphibians are now endangered and some species might be extinct. The shortfall of their number has increased insects creating an ecological imbalance. Ditches were very important components of the wetland ecosystem. They had environmental as well as economic contributions for the rural population.

A self-sustained population of fish was available every wet season in each of the ditches. Ditches of different sizes and depths were the fishing places during August through February. Fishes like shing, magur, guchi, garua, cheng, koi (discussed later with their biological and local names) would go in hibernation under the mud for the dry months of March and April, Those fishes would come out of their caves when the season's rain water would start accumulating in ditches. Overland run-off water would link almost all surface water bodies in the wet season. This would help in the mixing process of fishes from different surface water resources. Ditches were not usually protected from overflowing. These small surface water resources have been land filled and turned into agricultural land or other uses in the absence of the water availability in them. 

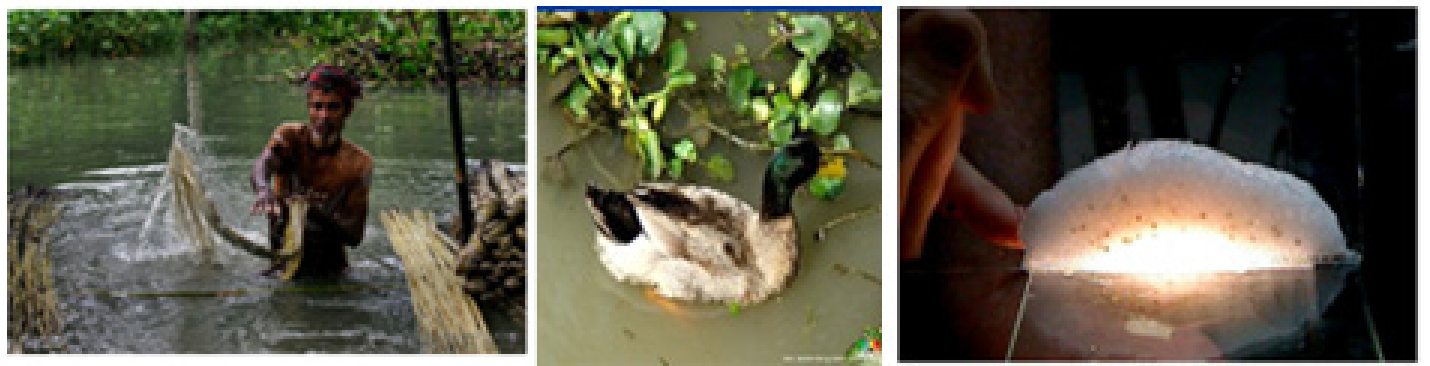

Figure 23. Illustration of ditch ecology. Jute-retting (left side inset) (http://www.flickr.com/photos/neerodsk r/6017128240/). Duck raising (middle inset, Panorama Bangladesh). Frog nests (courtesy of Times).

\subsection{Identities of the Gangetic Fishes}

There were about 109 species of fishes in the Ganges basin shown by drawings in Figs. 24a, 24b, and 24c (Islam and Hassan, 1983). The identities of these fishes have been provided below. Human actions have destroyed their habitats measuring more than $8,000 \mathrm{sq} \mathrm{km}$ in the Musa Khan basin alone (Adel, 2001). Many of the species are extinct now. The pre-piracy period annual average fish production was 277,000 metric tons. In the beginning of the nineties, it dropped to 185,000 tons. In the first two decades following the water piracy, Bangladesh lost Tk. 63, 000, 000,000.00 (US\$ 1,000, 000,000.00) in the fish production sector (Sattar, 1996).

Musa Khan's water would fulfill about $50 \%$ of the water budget for about $900 \mathrm{sq} \mathrm{km}$ of basin area. Prior to water piracy period, more than $97 \%$ of this basin area would remain inundated during July through October and wet later on except from March through May when canals, ditches and shallow floodplains would dry out (Adel, 1999a). This huge area was the natural breeding and raising grounds of the 109 species of Gangetic fishes as well as the groundwater recharging ground. It is hard to believe that this enormous natural aquatic habitat has been depleted.

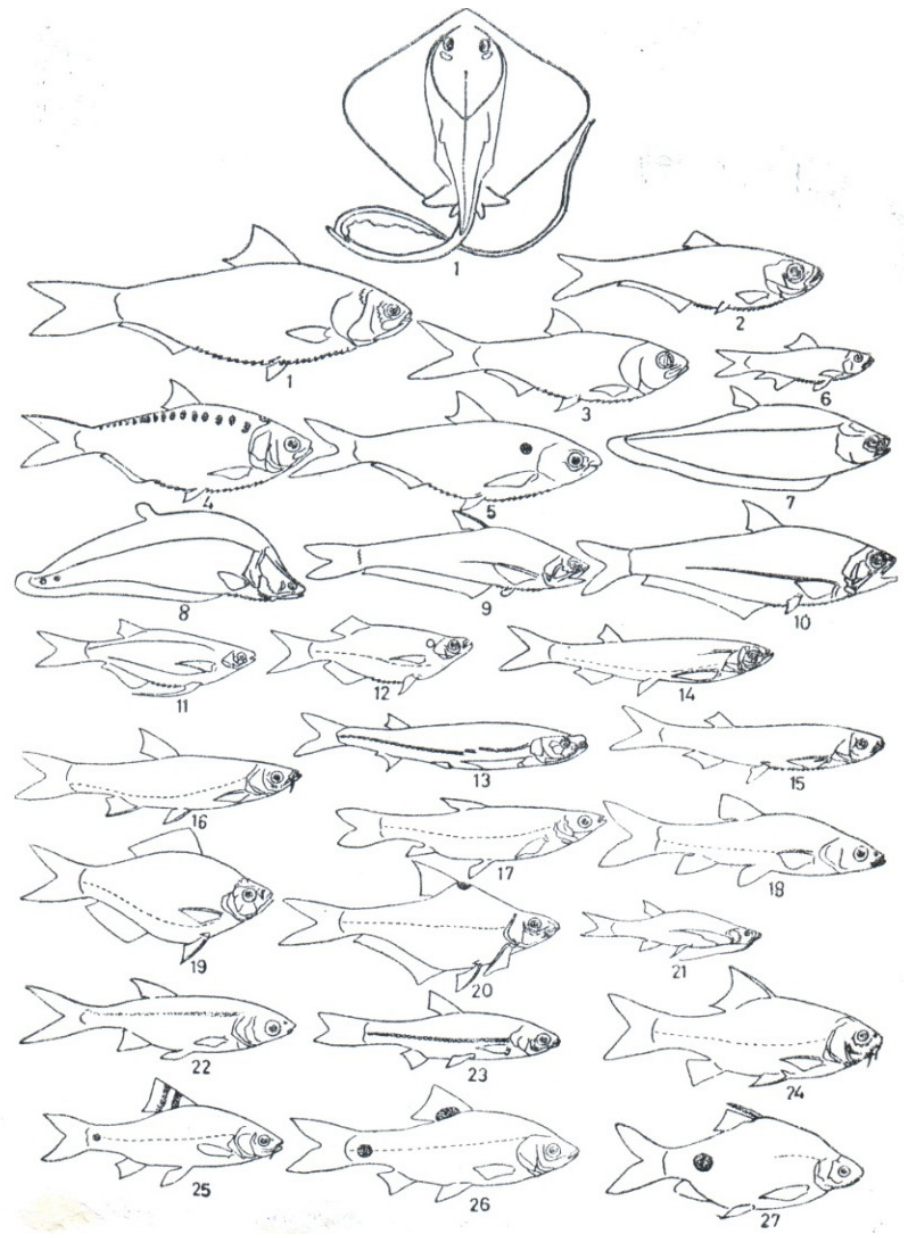

Figure 24a. Partial list of the Gangetic fishes (Islam and Hassan, 1983). 


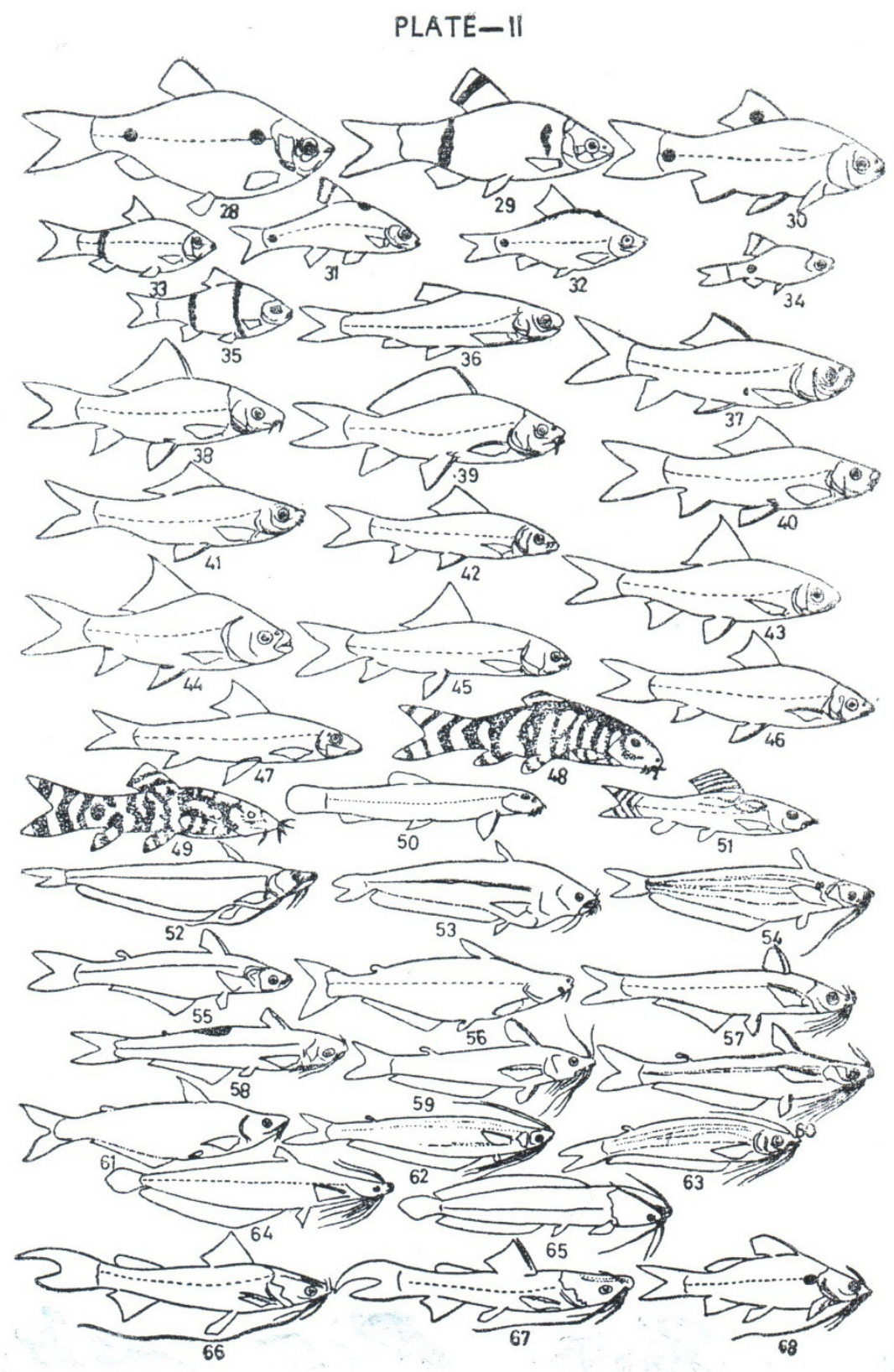

Figure 24b. Partial list of Gangetic fishes (Islam and Hassan, 1983). 


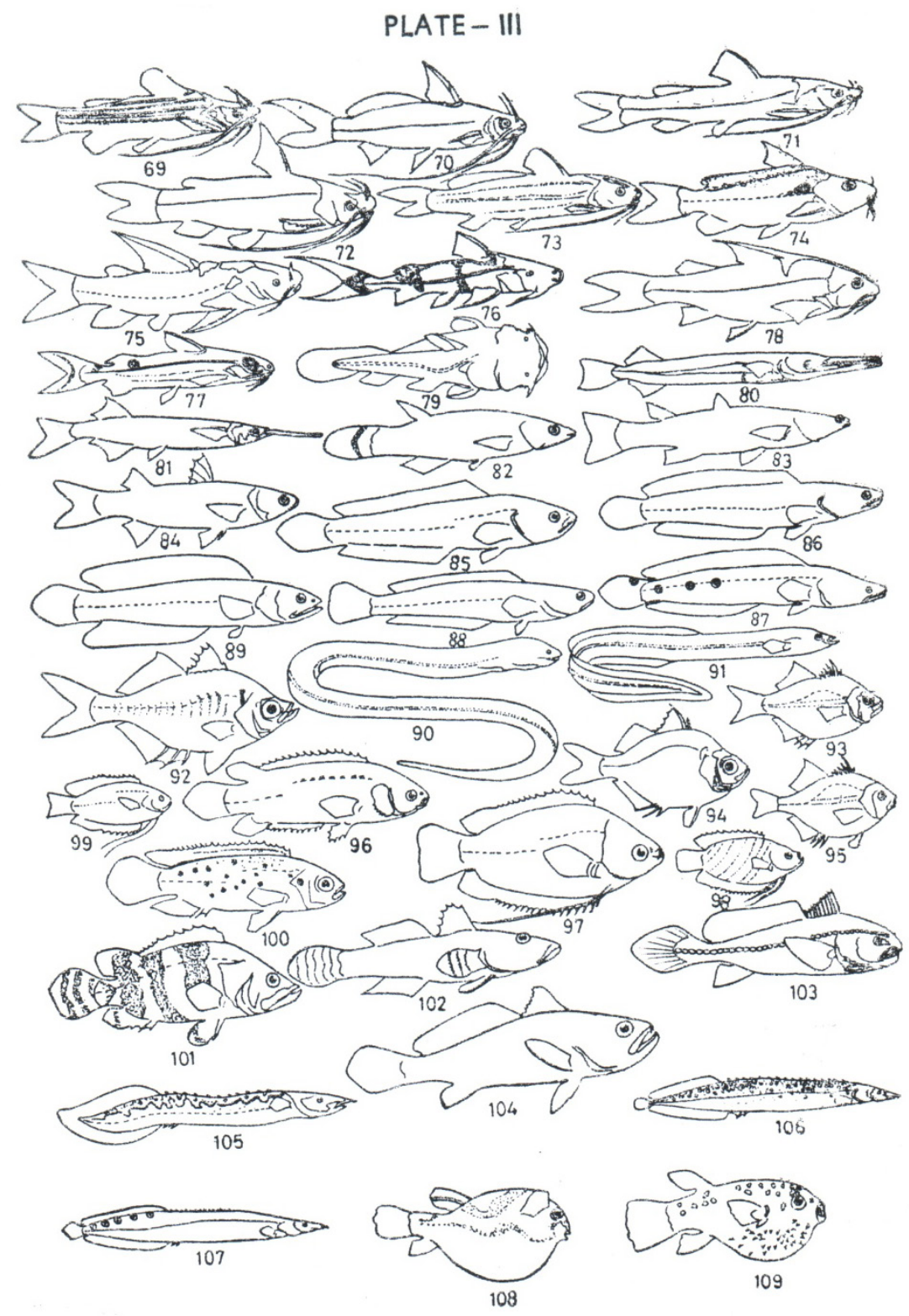

Figure 24c. Partial list of Gangetic fishes (Islam and Hassan, 1983).

For vividness of the bygone fish resources, photographs of the most of the Gangetic fishes appear in Fig. 25a, 25b, 25c, and 25d (courtesy of (http://en.bdfish.org/2010/11/fish-padma-rajshahi-bangladesh-1/; http://en.bdfish.org/2010/11/fish-padmarajshahi-bangladesh-2/; http://en.bdfish.org/2010/11/fish-padma-rajshahi-bangladesh-3/; http://en.bdfish.org/2010/11/fish-p adma-rajshahi-bangladesh-4/; http://en.bdfish.org/2010/11/fish-padma-rajshahi-bangladesh-5/; http://en.bdfish.org/2010/11 /fish-padma-rajshahi-bangladesh-6/) 


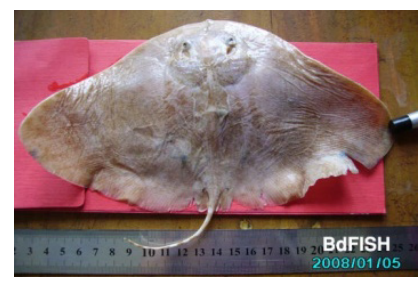

01

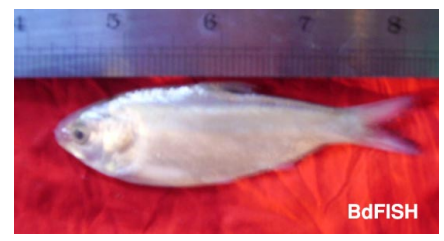

04

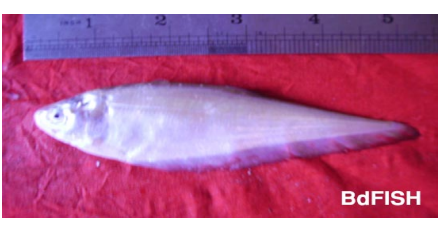

07

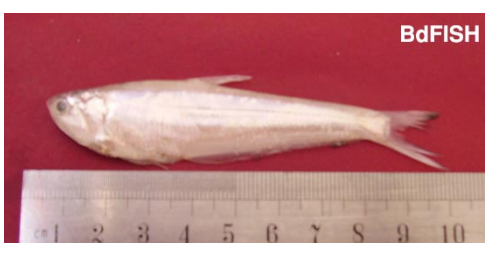

10

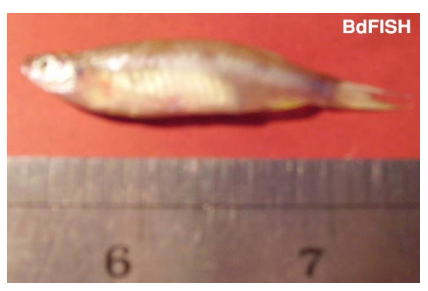

13

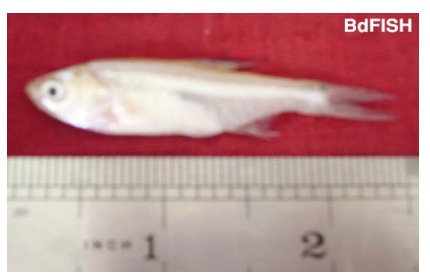

16

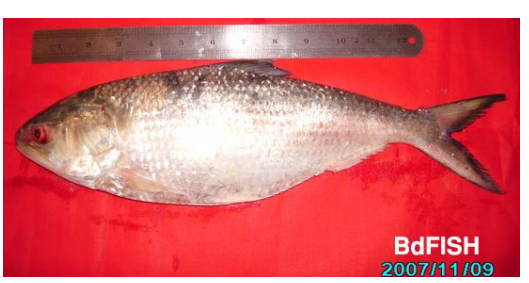

02

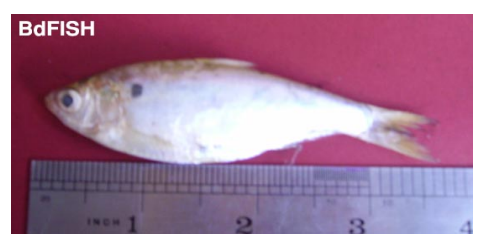

05

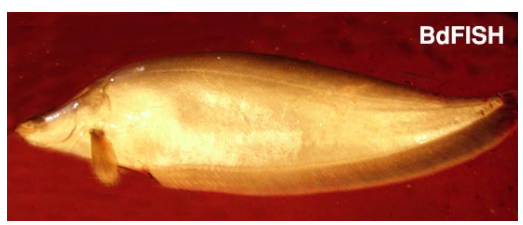

08

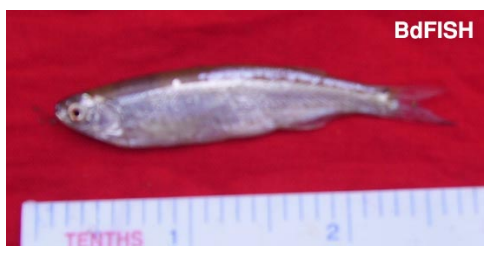

11

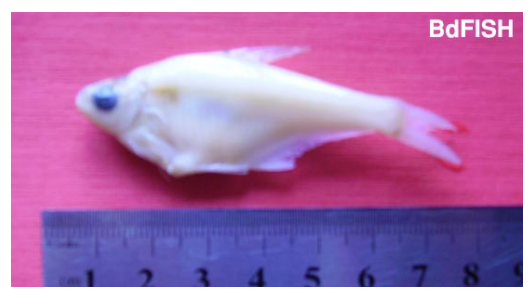

14

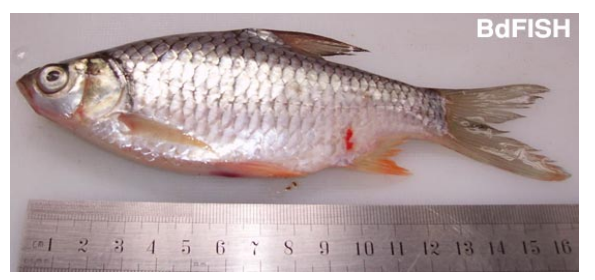

17

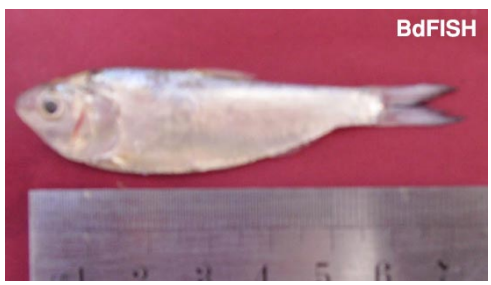

03

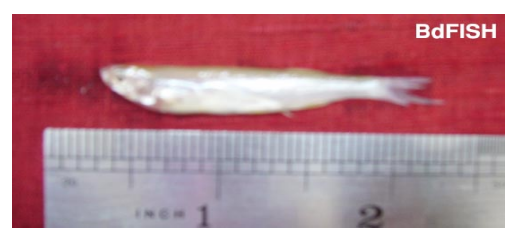

06

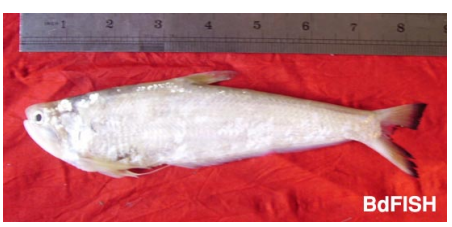

09

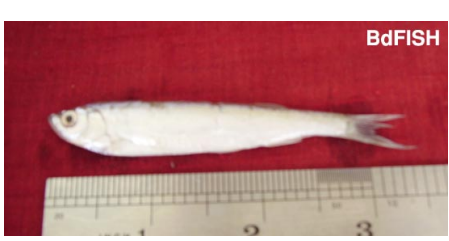

12

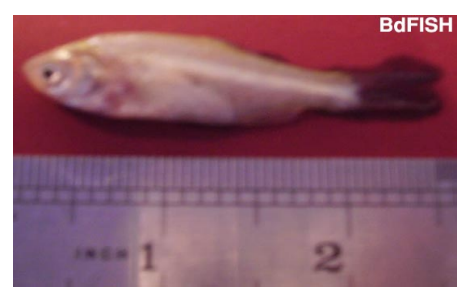

15

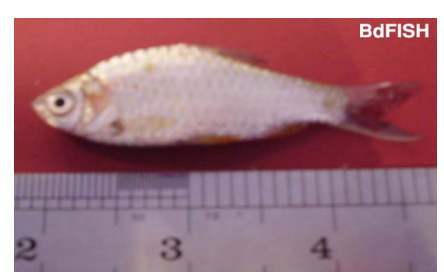

18

Figure 25a. Pictures of the Gangetic fishes 


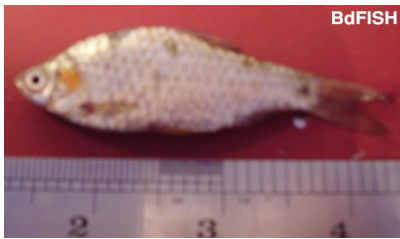

19

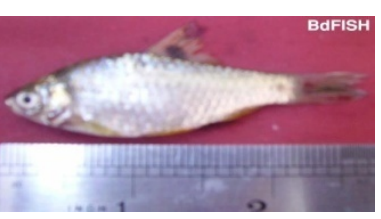

22

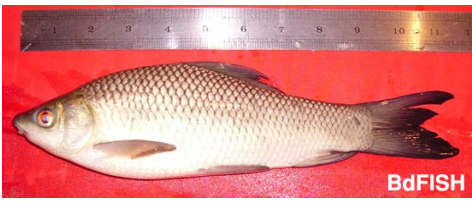

25

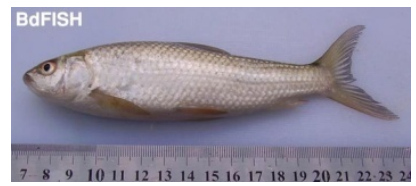

28

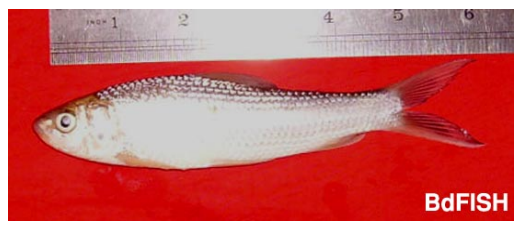

31

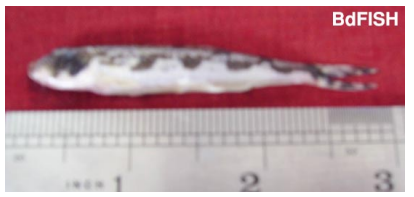

34

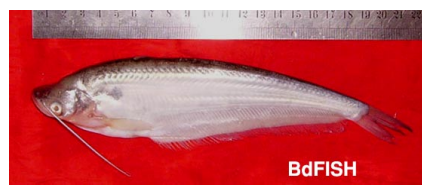

37

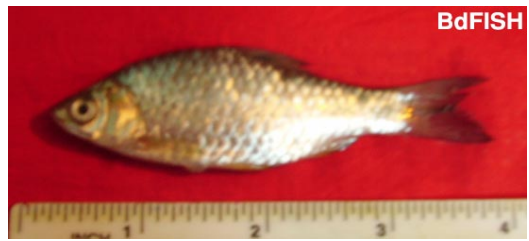

20

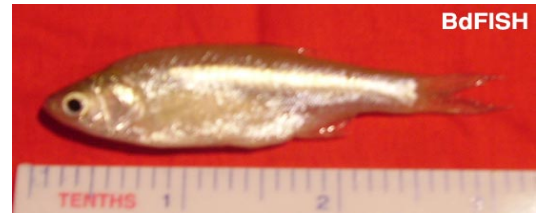

23

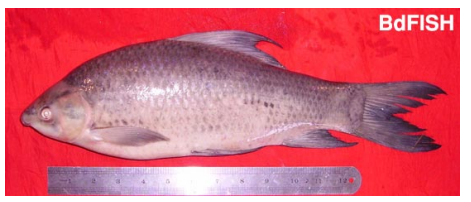

26

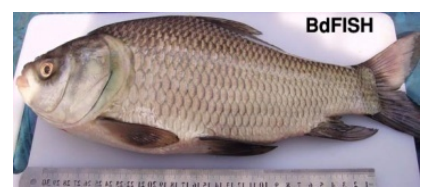

29

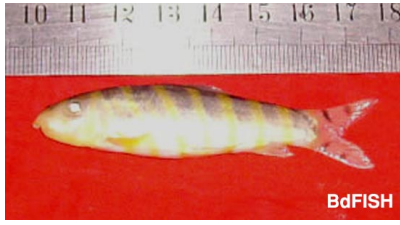

32

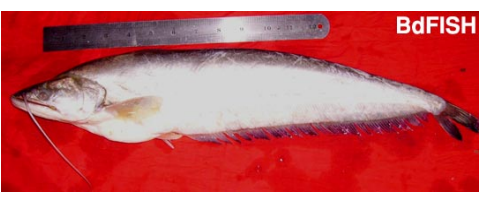

35

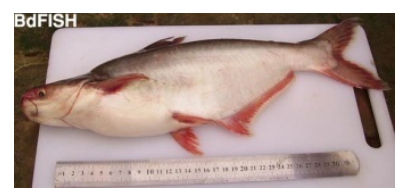

38

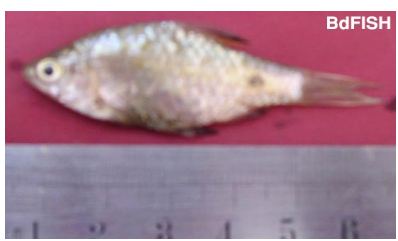

21

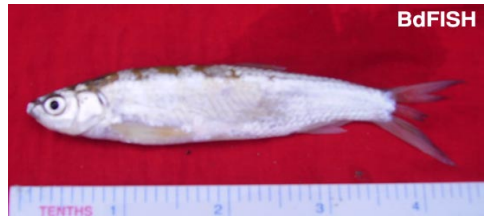

24

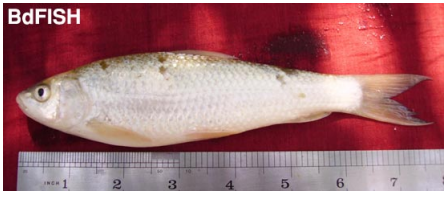

27

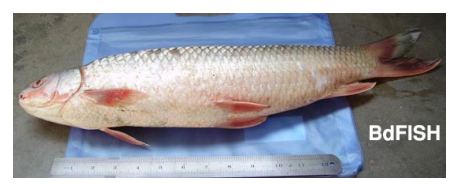

30

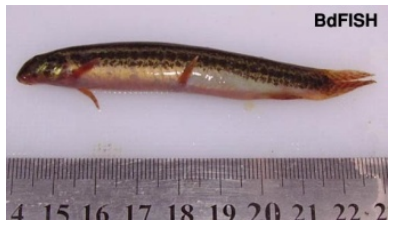

33

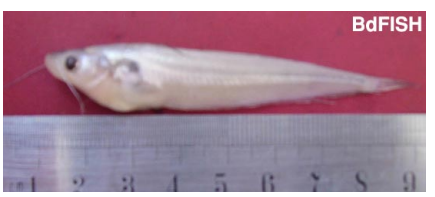

36

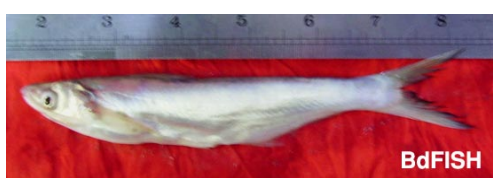

39

Figure 25b. Pictures of the Gangetic fishes 


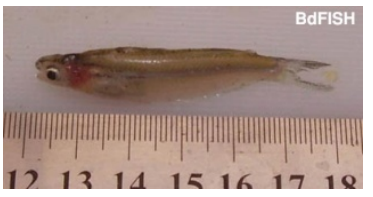

40

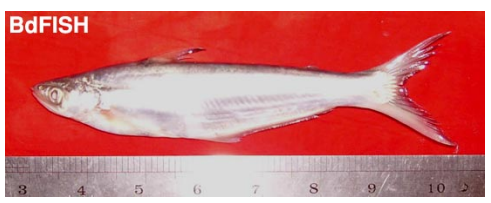

43

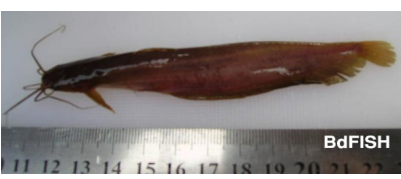

46

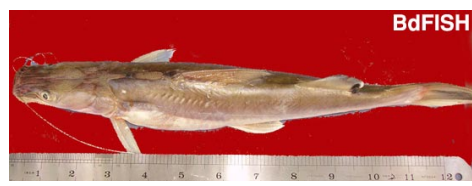

49

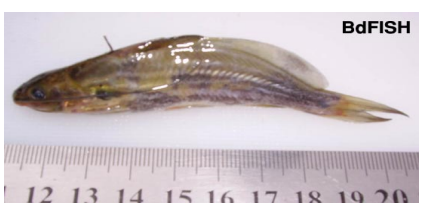

52

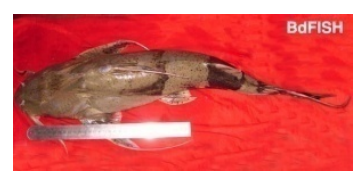

55

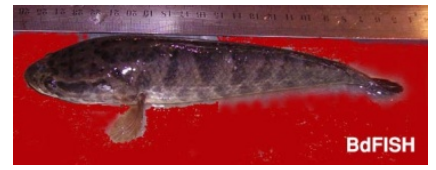

58

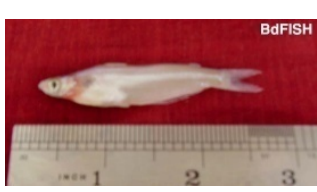

41

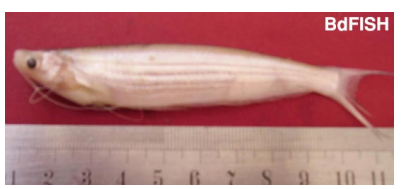

44

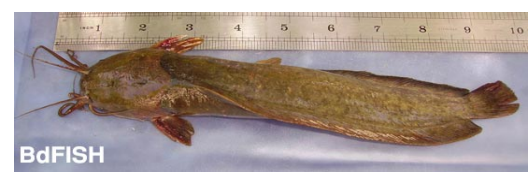

47

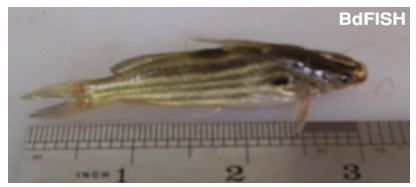

50

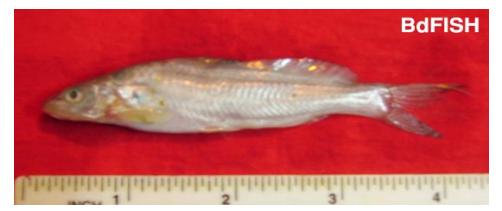

53

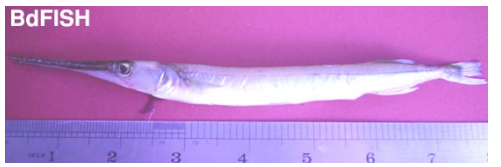

56

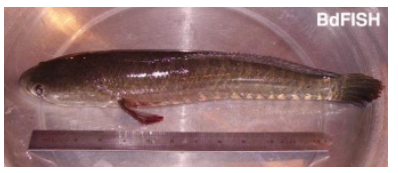

59

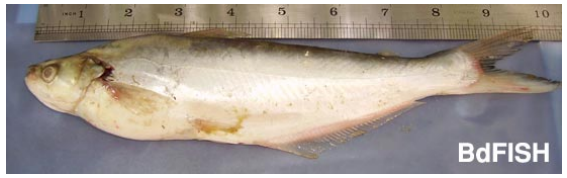

42

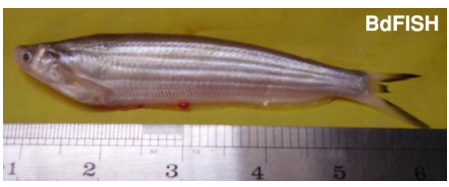

45

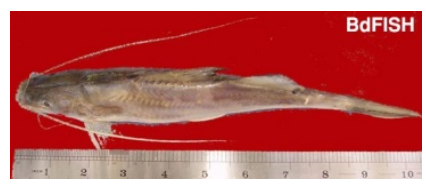

48

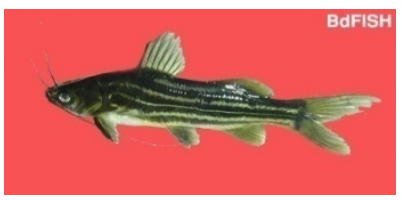

51

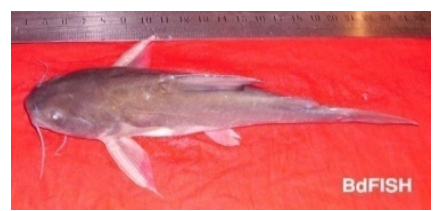

54

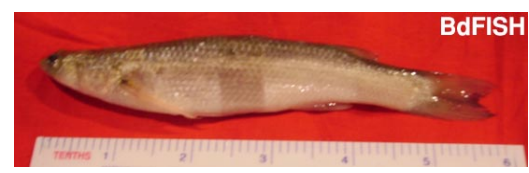

57

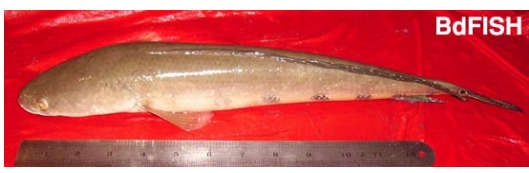

60

Figure 25c. Pictures of the Gangetic fishes.

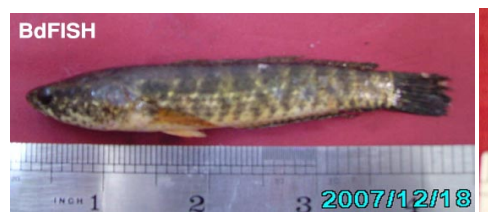

61

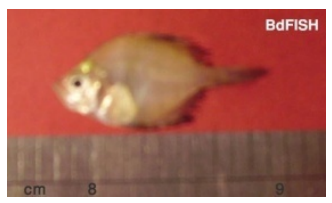

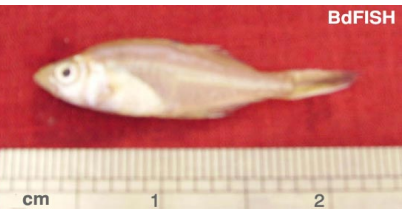

62

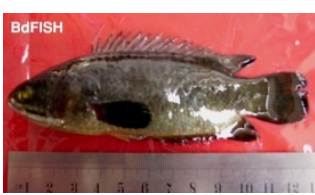

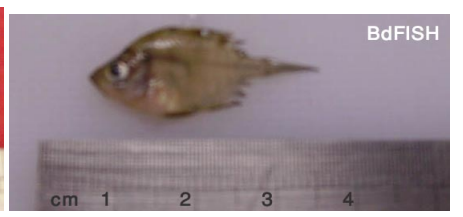

63
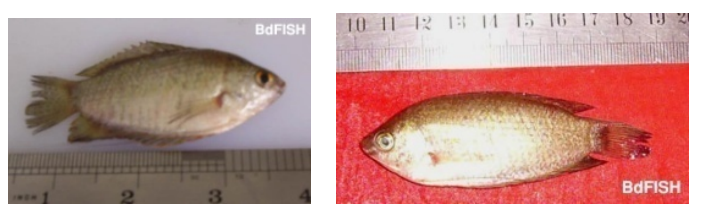
64

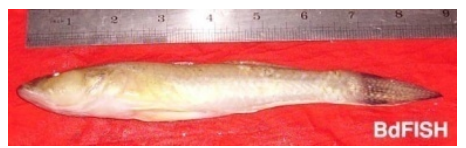

68

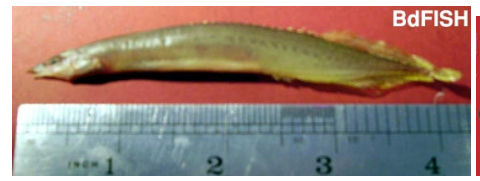

71
65

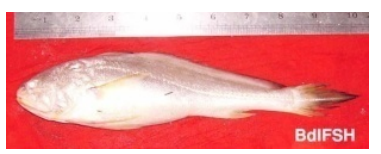

69

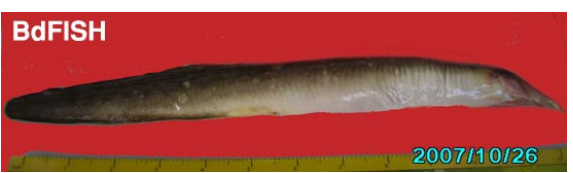

72
66

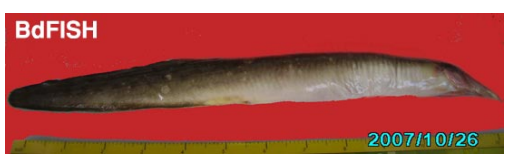

70

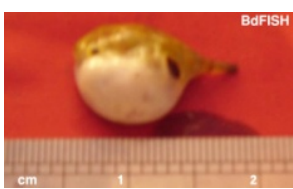

73

Figure 25d. Pictures of the Gangetic fishes

0.1 Trygon sp. It locally goes by by the name of sankoch mach. Having an unknown breeding season it used to be frequently found throughout the year. Its identifying information includes class- chondrichthyes, order-rajiformes, family-trygonidae, and genus-trygon 0.2 Tenualosa ilisha. This deep water sea fish is has the local name Ilish or Ilisha. It is marked 1 in Plate I. It used to come to the river for spawning. Its breeding time is the monsoon season. Hilshas are very oily fish and possess a special kind of aroma. It is the most popular kind of fish. Having eaten this fish, people would not need to take fish oil gels additionally. Its class is ostechthyes, order is clupeiformes, family is clupeidae, and genus is tenualosa 03. Gadusia chapra. This fis is locally known as chapila or khoira. Its breeding time is the monsoon season when it used to be abundantly found. Its specifications includes class-ostechthyes, order-clupeiformes, family- clupeidae, and genus-gadusia

0.4 Gadusia variegate. It used to breed profusely during monsoon season. Its taxonomic information is the same as of $\# 03$.

05. Gonialosa manminna. It used to be available in the post-monsoon season. . Its classifying information includes class-ostechthyes, order-clupeiformes, familyclupeidae, and genus-gonialosa

06. Corica soborna. It is locally known as kachki or gura mach. It used to be available throughout the year. Females with the pre-monsoon season bellyful eggs would have peak breeding in the monsoon season. Its class is Ostechthyes,Order-Clupeiformes, Family: Clupeidae, and Genus-Corica

0.7. Notopterus notopterus. Its local name is phalli or pholui. Egg-carrying females would be found in April-July. Its breeding time would be May-September. It classification includes class-ostechthyes, order-clupeiformes, family- notopteridae, and genus-notopterus.

08. Notopterus chitala. It is locally known as chital. Its available throughout the year. Its gravid female found in April-June and fries during June-September . It is a river fish with very small scales. It is \#8 in Plate I. It is a silvery white flat and oily body. Its size as large as $75 \mathrm{~cm}$ is seen. It is a very bony fish. It is a predatory fish. Chital-eaters would not need to take separately fish oil gels separately. Pond-owners are careful not to release chital spawn in the ponds. It is caught from rivers using bamboo strip-made fishing weapon called dhials (discussed below). Chital's taxonomy is the same as \#07.

09. Setipinna phasa. Having the local name phasa, and taxonomic information - class-ostechthyes, order-cupeiformes, family: egraulidae, and genus-stipinna, its gravid females would be found in the pre-monsoon for peak breeding in the monsoon season.

10. Setipinna taty. Having the local name teli-phasa and classification as class-ostechthyes, order-clupeiformes, family: engraulidae, and genus-setipinna, its pre-monsoon season's egg-carrying females would have peak breeding in the monsoon season.

(http://en.bdfish.org/2010/11/fish-padma-rajshahi-bangla desh-1/)

11. Chela atpar. Its local name is chela or pat-chela. This flat-bodied surface feeder fish is found mostly in ponds. Its peak breeding season is the monsoon season. Its taxonomic information includes order- cypriniformes, family: cyprinidae, and genus- chela.

12. Oxygaster bacaila Its local nane is narikeli-chela. This flat-bodied pond-raised fish is always seen playful on the surface of the water body (\# 14 in Plate I). They grow about $20 \mathrm{~cm}$ long. Compared to its body, its mouth opening is big. It is available round the year. Its peak breeding season is the monsoon season. Taxonomically, it differs from \#11 in in its genus called oxygaster.

13. Rasbora daniconius It is locally known as darkani. It would live in swarms (\# 17 and18 in Plate I). It would grow about $6 \mathrm{~cm}$ in length and would be found in flowing water of canals, floodplains, ditches, and floodplains. It was a shallow water fish and would stay in swarms on the water surface. It would be abundantly available during its peak breeding time the monsoon season. It is eaten with tender bones that adds to people's calcium. Its egg-carrying females would be available during June-July. Its taxonomy differs from that of $\# 11$ on in its genus which is rasbora.

14. Osteobrama cotio . Its local name is dhela and breeds in the monsoon season. The egg-bearing females would be seen in the pre-monsoon season. Its taxonomy is different 
from that of \#11 only in its genus- osteobrama.

15. Amblypharyngodon mola Its local name is mola or moa. They would be seen in swarms on the surface of water bodies. This flat-bodies tiny fish would grow $6 / 7 \mathrm{~cm}$. their body Molas are available round the year. Their peak breeding season was the monsoon season. Their gravid females would be available during April-August, and their spawns would be available during May-August. They are show in \#22 and 23 in Plate I. Molas are eaten along with its tender bones that makes them calcium-rich. Pond-owners catch them nighttime using some floating device on which they create some noise. Taxonomically, only its genus- amblypharyngodon is different from that of \#11.

16. Amblypharyngodon microlepis. With the local name mola, Molangi, moa, all descriptions of \#15 apply to it.

17. Puntius sarana Locally known as sar-puti would grow as big as $20 \mathrm{~cm}$. The fish was very tasty. Sar-puti's peak breeding season would be the monsoon time. In taxonomic information, only its genus- puntius differs from that of 11 .

18. Puntius chola. Local name is chola puti. Except for the growth of half the size of \#17, all the pieces of information of \#17 are applicable here. They would found in swarms and so caught in plenty in shallow canals. Being eaten with bones, they were rich source of calcium. They would be found in canals, floodplains, ponds, and ditches. They were available year-round. Fries would have rapid growth in the monsoon season. Unlike other fishes, their scales are larger compared to their body size.

19. Puntius stigma. Locally known as vanti punti. Other than a difference in appearance all the information of \#18 applies.

20.Puntius conchonius. It is locally known as kanchan puti. Only difference from \#18 is in appearance.

http://en.bdfish.org/2010/11/fish-padma-rajshahi-banglad esh-2/

21. Puntius ticto. Its local name is tit-punti. All descriptions of \#18 applies except for the difference in appearance. It has several sizes (\#24 through 35 in Plate I and II). The largest ones are called sar punthi. Some of the varieties have colorful bodies.

22. Puntius sophore. Its local name is jat punti or jati punti. All information of \#18 applies.

23. Aspidoparia jaya. It is locally known as jaya or choto-peoli. Having their availability throughout the year, their gravid ones would be found twice a year - May through August and December through January. Following the season's first availability of rainfall in June, fries would be available up until September. Their specifications include order- cypriniformes, the family: cyprinidae, and the genus- aspidoparia.

24. Aspidoparia morar. Its local name is peoli. As with other fishes, its peak breeding time would be in the monsoon season. Its gravid ones would be available during May through August, and fries July through September. Its taxonomic information is the same as in
\#23.

25. Labeo rohita. It is locally known as rui, rohit. It is available round the year. It breeds in shallow water during the monsoon season. Its gravid females are found during April-July, and fries are available during July-September. It is a river fish (\#37 in Plate II). It has almost dime-size glossy scales. It used to be raised in abundance in ponds. Its young one are called losi (lo-see) and look very pretty. Professional fishermen would catch the spawns from the river and sell them to the pond-owners. It is a very popular kind of fish. The taxonomic information of rohit includes its order- cypriniformes, family: cyprinidae, and genuslabeo

26. Labeo calbasu. Its local name is kalibaus because of it's a bit darker appearance than chital, rui, or katal. Being raised in ponds, too, it used to be available throughout the year fish (\#38 in Plate II). In pond-raised fishes, its number would be the least compared to that of other fishes of its size. Fishermen would supply the spawns to the pond-owners. It breeding time was monsoon. Its gravid female were found during April-July, and fries in July-September. Its taxonomy is the same as of \#25.

27. Laneo bata. Its local name is vangna, bata. It would be available would be year-round. Its gravid ones would be available from pre- to mid-monsoon and breeding would take place mostly in the monsoon season. Fries would be available June through September. Its taxonomic classification is the same as \# 25.

28. Labeo boga. It is locally known as bhangon, bhangon buta. Its breeding would take place in the monsoon season, fries would be available in August through September. The taxonomic information is the same as of \#25.

29. Catla catla. Its local name is katla, katol. It used to be available throughout the year because of raising in ponds. Pond-owners would get its spawns from professional fishermen who would catch them from rivers. It breeds in monsoon and summer time. Its gravid female is found during May-July, and fry found in early monsoon. It grows very well in ponds (\#44 in Plate II). Large catlas are quite heavy. Large ones grow about the size of ruhia. The central or the middle part of catlas is wider than ruhia or hilsha. Its opening of the mouth is the widest of all fishes except boal discussed below. Its scales are dime size, too. It is more like buffalo fish in the USA. Taxonomically katla falls in order cypriniformes, family in cyprinidae, and genus in catla

30. Cirrhina mrigala. Common people call it mrigal, mirka. Because of raising in ponds, it used to be available throughout the year (\#45 in Plate II). Pond-owners used to buy its spawns from the fishermen during the monsoon when it breeds. Professional fishermen would catch the spawns from rivers using nets. Its gravid female found in June-August and fry in July-September period. It is available in rivers also. It is more like ruhia in many respects. Its body is more of uniform thickness than other fishes. In taxonomic classification, its genus- cirrhina is different from that of \#29. 
http://en.bdfish.org/2010/11/fish-padma-rajshahi-banglad esh-3/

31. Cirrhina reba. Common people know it as raikhor). It was a very tasty fish. It would look like young Ruhia. It would be available throughout the year. Monsoon season is its breeding season. Its gravid females would be found during April-August and spawns during June-September. Rivers, canals, floodplains, and ponds were its habitats. It differs taxonomically from \#30 in its genus- cirrhina.

32. Botia dario . Locally is known as rani, bau. It would be available year-round. Egg-bearing females would be found May through June and breeding would take place in the monsoon season. Fries would be available July through August. Taxonomic information puts it in ordercypriniformes, family: cobitidae, and genus- botia .

33. Lepidocephalus guntea. People knows it as puiya, gutum. Without exception from other fishes, gutum would be available all through the year, breeding would take place in the monsoon season following the availability of the gravid female found during April through August. Fries would be available in the months of June through September. Its genus genus- lepidocephalus differs from that of \#32.

34. Somileptes gongota. People calls it gutum, pahari gutum. Its gravid females would be available in April through August. Its would breed in the monsoon. Fries would be seen during June through September. Its genussmileptes is different from that of \#32.

35. Wallago attu. It is known to people as boal (bo-al).It used to be available throughout the year. It used to breed in the monsoon in the shallow water. Gravid females were found during April-May and fries were available during June-September. It can grow quite big and quite heavy (\#52 in Plate II). Its size as large as $90 \mathrm{~cm}$ has been observed. It is available more in sizes of about $75 \mathrm{~cm}$ than other sizes. Its scales are very small compared to its body size. Its body is less bony fish than others. Because of this, its body sags down once it is put out of water. It swallows young fishes, frogs, small snakes, etc. It is a predatory fish. If one boal is found in a pond, other population will decrease. People used to catch them by passing a hook through a live frog or small fish or a grasshopper. The hook is attached to string, and the other end of the string is tied to a rod fixed in the ground. It is not like regular angling in which case the angler has to be present to catch fish. Boal is classified as order- siluriformes, family: siluridae, and genus- wallago.

36. Ompok pabda. Its local name is pabda, poba. It looks like a small boal. It would be raised in canals and floodplains ( $\# 53$ and 54 in Plate II). It would grow about $15 \mathrm{~cm}$ long. More or less, it would be available throughout the year. Its breeding season is the monsoon season. Its gravid females would be found during April-May, and spawns during June-September. Only its genus- ompok is different from that of \#35..

37. Ompok bimaculatus . Locally it is known as kani pabda. It would be available throughout the year having the breed time in the monsoon. Its gravid females would be found during April through May. Fries would be found during June through September. Its taxonomic information is the same as \#36.

38. Pangasius pangasius. Its local name is pangus. It would be available throughout the year. It would breed in the monsoon in the shallow water. Its gravid females would be found in June. Native pangash (\#54 in Plate II) would grow very large - about the size of an adult human. It needs a bullock cart for transportation. Fishermen would catch it in the river and bring to market place for selling in pieces. Several families would buy one whole pangus. Pangus's taxonomy includes order- siluriformes, family: pangasidae, and genus- pangasius

39. Clupisoma garua. People call it ghere, gharua. Ghere's breeding time would be the monsoon season and place would be shallow water. Females of ghere would bear eggs in June. It is a river fish and less oily than bacha (\#57). It is caught in the size as bacha. Its mouth is a little reddish. It is not raised in ponds. Fishing weapon dhials were used to catch it from rivers by common people. Its taxonomical information includes order- siluriformes, family: schilbeidae, and genus- clupisoma,

40. Clupisoma atherinoides. It is locally known as batasi. It would be available throughout the year and would breed in the monsoon. Females would bear eggs during May through July, and its fries would be available during July-September. Its taxonomic information is the same as \#39.

http://en.bdfish.org/2010/11/fish-padma-rajshahi-bangla desh-4/

41. Clupisoma taakree. Its local name is tin-kata. Like other fish species, it used to be available throughout the year. Its females would bear eggs during May through July, and breeding would take place in the monsoon. Its fries would be seen all through the monsoon. Its taxonomy is the same as in \#40.

42. Silonia silondia (Local name: Shilong). As usual for the Ganges basin fish, it would be available all the year-round with the monsoon season breeding time and July through September fries' availability time. Shilong's oder and family are the same as of \#40 but the genus is silonia.

43. Eutropiichthys vacha .This very oily fish is locally known as vacha. Its breeding time used to be the monsoon season. Its fry availability time would be the entire monsoon season-July through September. It (\#61 in Plate II) would be caught flooded rivers using the fishing gears called dhials (discussed later) season by common people. Its scales are quite small compared to it body. It would be caught in sizes of 25 to $35 \mathrm{~cm}$. This popular river fish's order and family are the same as in $\# 40$ but the genus is eutropiichthys

44. Ailia coila. Having the local name kajuli, this fish species would be available all through the year. Its breeding would take place in the monsoon. Its females would carry eggs in pre-monsoon and early monsoon. Its 
fries could be seen in July through September. Its genus is ailia but the order and family are the same as of \#40. 45. Ailiichthys punctata. It is locally known as banshpata. Its taxonomic order and family are the same as of $\# 40$ but the genus is ailiichthys. It would be available all the year-round with the noted monsoon season as the breeding time. Its females would carry eggs May through July and fries July through September.

46. Heteopneustes fossilis. People used to scared of stinging by this fish called shing while trying to catch it from shallow water in mass fishing in floodplains, canals, or ponds. Having the monsoon as the breeding season, gravid females' availability during April-July and fries in June-August, shing would be available throughout the year because of the lasting of the fishing season with gradually decreasing water in ditches, canals and floodplains. This fish grows 25 to $30 \mathrm{~cm}$ long (\#64 in Plate II). It is dark in appearance with a light reddish tinge. This slippery-bodied fish does not seem to have scales in its body. It has two poisonous thorns on either side of the head. That is why they are hard to catch. It is found in ditches, canals, and floodplains. This fish makes some kind of squeaking sound. This fish lives in groups in cavities in the shallow part of the water body. This is a bottom feeder fish. People include this fish in the sick persons' diets. Taxonomy of this variety of fish includes order- siluriformes, family: heteropneustidae, and genusheteropneustes

47. Clarius batrachus. This is another variety of fish called magur used in sick person's diets. As the drying of the surface water resources would continue till the advent of the monsoon, magur fish would be available throughout the year with the breeding time in the monsoon. It gravid female would be available during May-June, and fries in June-September. Its shape is like that of a cat fish raised in the USA and Africa but tastes much, much superior to it.. It is numbered 65 in Plate II. It is available in sizes of about $30 \mathrm{~cm}$. Its scales are very small. It is found in ditches, ponds, canals, and floodplains. Its taxonomy includes order- siluriformes, family: claridae, and genus- clarius. 48. Mystus aor. Its local name is guji air. It would be available any time of the year having monsoon as the breeding season. Its gravid female would be available during May through July, and fry during in June through September. The taxonomical information of this species of fish includes order- siluriformes, family: bagridae, and genus- mystus.

49. Mystus seenghala. Its local name is taila air. It would be available throughout the year having the breeding time in the monsoon season. The gravid female would be available during May through July, and fry during June through September. The taxonomic information of this fish species is the same as of \#48.

50. Mystus tengara. It is locally known as bujuri tengra. Its taxonomic information is the same as of \#48. It would be year-round available. Its breeding time would be the monsoon season. The gravid female would be available during May through June, and fry during June through September.

http://en.bdfish.org/2010/11/fish-padma-rajshahi-bangla desh-5/

51. Mystus vittatus . It is locally known as tengra. It would be available throughout the year. Like all other fish species monsoon was its breeding time. Its females would have eggs during April-July and fry in July-September. The taxonomic information is the same as that of \#48.

52. Mystus cavasius. It is locally known as kabshi tengra. Having the monsoon season as the breeding time, it would be available throughout the year. Gravid females would be seen during April-July and fry in June-September. The taxonomic information is the same as that of \#48.

53. Mystus bleekeri. Its local name is gulsha tengra. Its breeding season was the monsoon. Its gravid females would be available during April-July, and fries in July-September. It grows about $20 \mathrm{~cm}$ long. It is numbered 68 through 74 and 77 in Plate II and III. It has two defensive thorns near the operculum on either side of its head. It burns if the fish can sting its thorns in the catcher's finger. It has lateral lines on its body. Its scales are small. It is found in ponds, canals, and floodplains. River-raised tangras are larger than the regular size. Because of its body structure, its flesh to bone mass ration is disproportionately smaller than for similar size fishes. Its taxonomic information is the same as of \#48.

54. Rita rita. The local name is rita. It used to have more or less availability throughout the year. It females carry eggs during April-July, and fries are seen in May-September. Monsoon time is the breeding season. Its genus is Rita and that is what differs from the taxonomic information of \#48.

55. Bagarius bagarius. Its local name is baghair. Its gravid females are seen during May-June. The monsoon season being the breeding time, its fries are seen in during June-September. It used to be available throughout the year. Its taxonomic class information includes ordersiluriformes, family: sisoridae, and genus- bagarius.

56. Xenentodon cancila. It goes by the local name kaikka, kakila. Its egged females are seen during April-Jully. Its breeding time being the monsoon season, fries are seen during June-September. It used to be available throughout the year. Taxonomically its order is beloniformes, family belonidae, and genus xenentodon.

57. Rhinomugil corsula. It is locally known by korsula and $u r o l$, Its egged females would breed in the monsoon time and fries would be seen during June-September. It would be available throughout the year. Its order is mugiliformes, family mugilidae, and genus rhinomugil 58. Channa punctatus. Locally it goes by the name of taki. It would breed in the monsoon and winter. Egg-bearing females were seen during February- October. Fries wer seen during March-September. It order is channiformes, family channidae, and genus is channa

59. Channa striatus . People calls it shol. It used to have year-round availability. Its gravid female would be 
available during May-July. It would breed in shallow water in the monsoon and fries would be available in June-October. The mother would take around hundreds of fries by the shallow water in the ditch, canal, floodplain, or pond. This shallow water fish (\# 86 in Plate III) is principally found in ditches and floodplains. Its body is cylindrical with gradual thinning toward the tail side. It can grow about $40 \mathrm{~cm}$. It is a predatory fish. Its eating habit is like that of boal. It can be caught the same way as boal or by regular angling. Its top color is blackish brown and the bottom color is white. Its scales are small. Its taxonomic information is the same as \#58.

60. Channa marulius . Local people calls it gojar. It would be available throughout the year. Gravid females used to be seen in the pre-monsoon time, and fries during June-September. It has the same taxonomic information as \#58.

\section{http://en.bdfish.org/2010/12/fish-padma-rajshahi-bangla} desh-6/

61. Channa gachaua. Its local name is cheng. It would breed during monsoon. Its pregnant females would be available during April-July and fry in June-October. This species of fish (\#88 in Plate III) is found where gari is found. It is of the same size as gari. However, it is more selective than gari in eating its bait. Its scales are small. It taxonomy is the same as $\# 58$

62. Chanda nama. Its local name is chanda. Chandas would be abundantly seen in their breeding time monsoon season. Gravid females would be available during April-July. They are colorful small fish (\#92 through 95 in Plate III). Some people use them in home aquariums. They grow about $5 \mathrm{~cm}$ in size. It has more bones than flesh. In the flowing water of canals, they are seen to move in swarms. Its taxonomic position includes orderperciformes, family centropomidae, and genus- chanda 63. Chanda baculis. People call it phopha chanda. It would be available throughout the year. Its breeding would take place in the monsoon. Gravid female available during April-June and fry in June-September. Like the \#62, it is more bony than fleshy. Its taxonomy is the same as \#62.

64. Chanda ranga. Its local name is lal chanda. It had year-round availability. As is with the other varieties, the breeding would take place in the monsoon season. Gravid females would be available during April-July and fry during June-September. Its taxonomy is the same as \#62. Chandas enjoy water current in canals.

65. Anabas testudineus. This popular fish variety goes by the name koi. It used to be available almost throughout the year because of drying of ditches and floodplains of different depths at different times. Its breeding time was the monsoon. It gravid females were available during March-July and fries in May-September. The mother would be observed to take around hundreds of fries the sides of ditches, ponds, canals, floodplains. This is an interesting species of fish (\#96 in Plate III). The body of this shallow water fish is thorny. It is a strong fish. Its body moves even after processing and putting on the cooking pan. Its biggest size can be about $25 \mathrm{~cm}$. Its scales are big compared to its body. It is a very mobile fish. It can move from one water body to another across a dry land by using its operculum. Its anterior dorsal, posterior dorsal, and pelvic fins are strong and long. Its strong and stout body is favorable for migrating from one place to another. Because of this features, it is difficult to keep them confined in a particular water body. It is available in ditches, ponds, canals, and floodplains. People include this fish in the sick persons' diets. People can knit a special kind of nets for catching $k o i$ in floodplains and paddy fields. Large size kois are caught in October-November using the net. Its taxonomic order is perciformes, family anabantidae, and genus anabas

66. Colisa fasciatus. The local name of this species of fish is kholsha. This small fish would be available throughout the year with abundance in the rainy season. Its breeding time is the monsoon season. The egg-bearing females would be available during April-June, and fries during June-September. It body is very bony. Its taxonomic information is the same as \# 65 except the genus which is colisa

67. Colisa sota. It is locally known as chuna kholisha. Its taxonomical identities are the same as \#66. It used to be available throughout the year. It would, breed in the monsoon. Its gravid female would be available during April-June and fries in June-September. Its body is like a small koi as far as thorns are concerned (\#97 in Plate III). It can grow about $10 \mathrm{~cm}$. Its scales are large compared to its body like that of koi. Some are quite colorful. They live in open and flowing water like canals and floodplains. They stay in swarms. Because of their playful nature in water, people keep the colorful petty ones in aquarium.

68. Glossogobius giuris. People knows it by the name baila or bele. It used to be a shallow water fish. It does not have red color blood in it. It used to be available throughout the year. Its breeding time used to be the monsoon season. Its egged-females would be available during January through February, and fries would be available twice a year - July-September and February-March. The taxonomical information of this species of fish is order- perciformes, family: gobidae, genus- glossogobius.

69. Pama pama . Its local names are bhola and poa. Like other species of fishes it would be available all through the year. Its breeding would take place in the monsoon. They would carry eggs during April through June for giving birth to fries in in May through September. The taxonomical identity includes oder- perciformes, family: sciaenidae, and genus- pama.

70. Mastacembelus armatus. The local names are gonti and baim. It is a bottom feeder fish. It was said to have some medicinal value. It would be available throughout the year. The breeding would take place during the monsoon season. The mature female would have eggs during May through July for spawning in June through 
October. Its taxonomic information includes ordermastacembeliformes, family: mastacembelidae, and genus- mastacembelus.

71. Mastacembelus pancalus It is known to people as guchi. It would be available throughout the year. Its breeding would take place in the monsoon. The gravid females were available during April-June, and the fries in June-September. It is one of the bottom feeders (\#105, 106, and 107 in Plate III). Its head is pointed. It is found in about $25 \mathrm{~cm}$-long sizes. It has small scales. Its taxonomic information is the same as of \#70.

72. Macrognathus aculeatus . People call it tara baim. Its availability would be all through the year. Like other fish species, its breeding time would be the monsoon season. The egg-bearing females would be found in April through June, and fries in June through September. Its taxonomy is the same as of $\# 70$.

73. Tetraodon cutcutia. Its local name is potka. It breeds in the monsoon making fries fry available in July-October http://en.bdfish.org/2010/12/fish-padma-rajshahi-banglad esh-7/

74. Local name bheda. Its shape is like that of koi but not as bony as a koi (\#101 in Plate III). It is a soft and weak kind of fish. It is available in canals, floodplains, and ditches. In nature, its population was not as much as other small fishes of its sizes. Its scales are small. Its taxonomy should be that of $\# 65$.

75. Garua. They grow in abundance in ditches (\#85 in Plate III). Some are found in shallow water of floodplains and canals. Its largest size is about $25 \mathrm{~cm}$ in length. It has small scales. Its taxonomy should be that of \#58.

76. It would be incomplete if shrimp which belongs to the seafood community is not mentioned in the discussion of the extinct aquatics for this dead river basins. They would be available in rivers, floodplains, and canals. Their sizes were about $6 \mathrm{~cm}$.

Had there been water bodies as of pre-piracy period, millions of fries would be produced the possibility of which was completely eradicated by the water pirate who is an ecocide criminal. This is a part of global change. While there is the global concern for global changes, this uniquely and acutely concern-raising changes, however small that be, must be brought to global attention.

Riverine Bangladesh's each part was self-sufficient in producing fishes except for the most favorite fish hilsha, which not being plentiful inland, would be distributed from the southern part of the country.

Perennial rivers full of aquatics have been rendered seasonal or dry. The Baral River is now a seasonal stream. All of the living beings have been extinct over the decadal period.

Species- and season-wise huge amounts of fish catch from all surface water resources in the pre-piracy period is shown in Figs. 26a and 26b. These fish catch was done by the villagers excluding professional fishermen living on the banks of the river. For over three decades, these productions have been stopped. Fish prices are exceedingly high. Common people cannot afford to buy what used to be a stone's throw away from them.

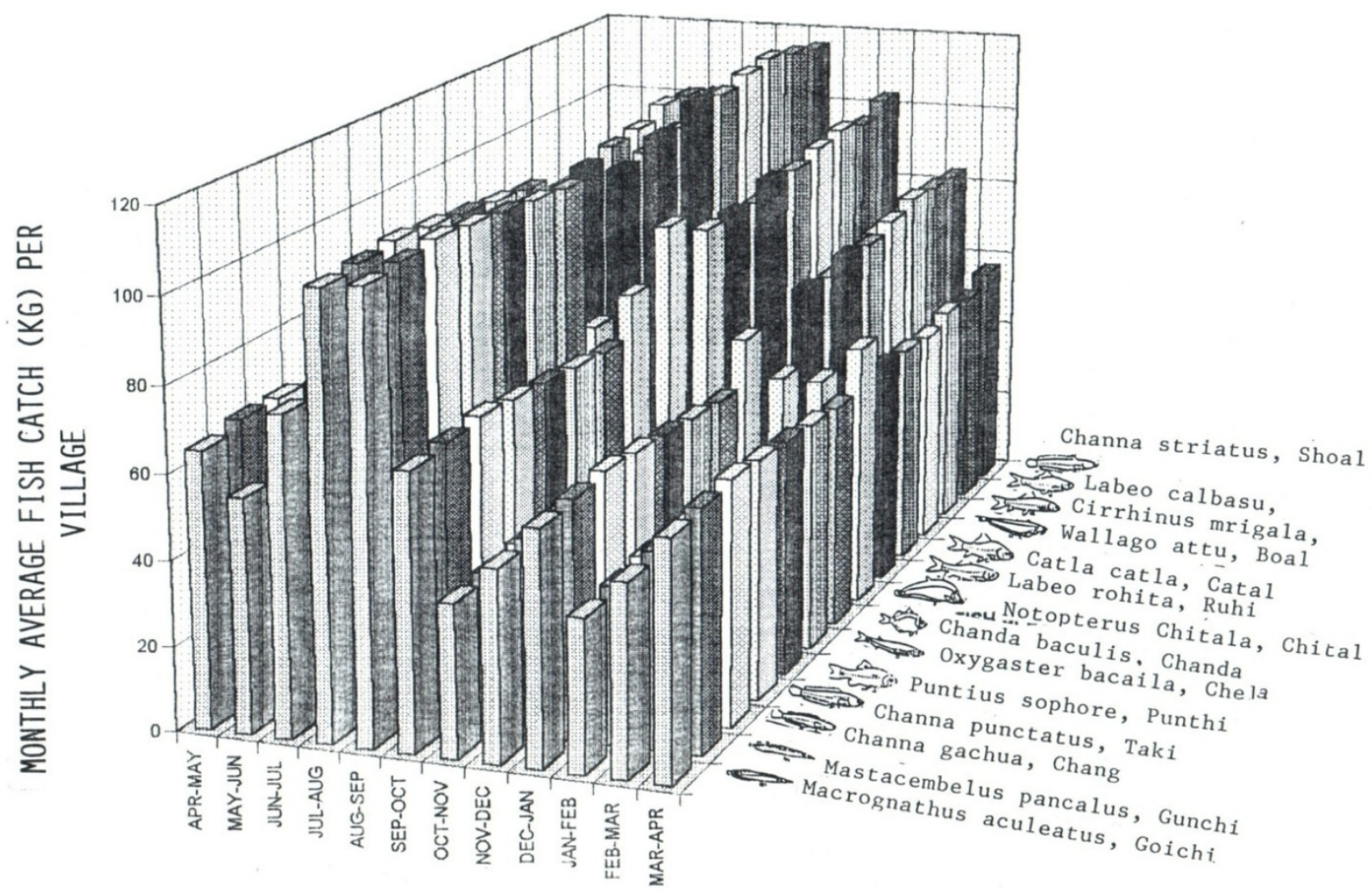

Figure 26a. Species- and season-wise fish catch per village from all surface water resources in pre-piracy period. 


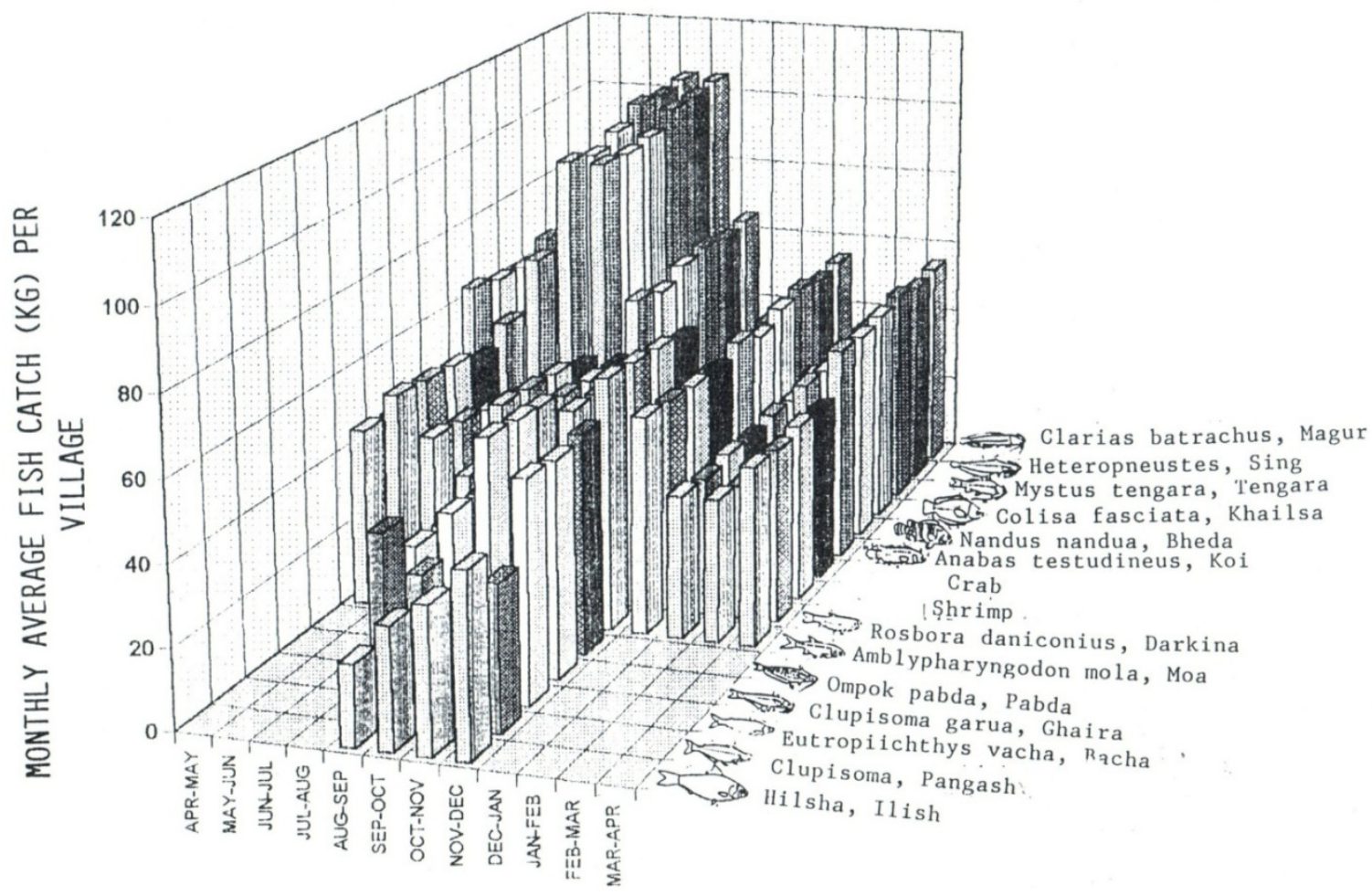

Figure 26b. Species- and season-wise fish catch from all surface water resources per village in pre-piracy period.

The source- and season-wise fish catch in $\mathrm{kg}$ in a rural unit is plotted in Fig. 27 for the pre-piracy period. The amount of fish production decreases in this order of the sources - rivers, floodplains, ponds, canals, and ditches. The larger amounts from some of the sources were because of their larger and deeper expanses and longer water retention capacities.

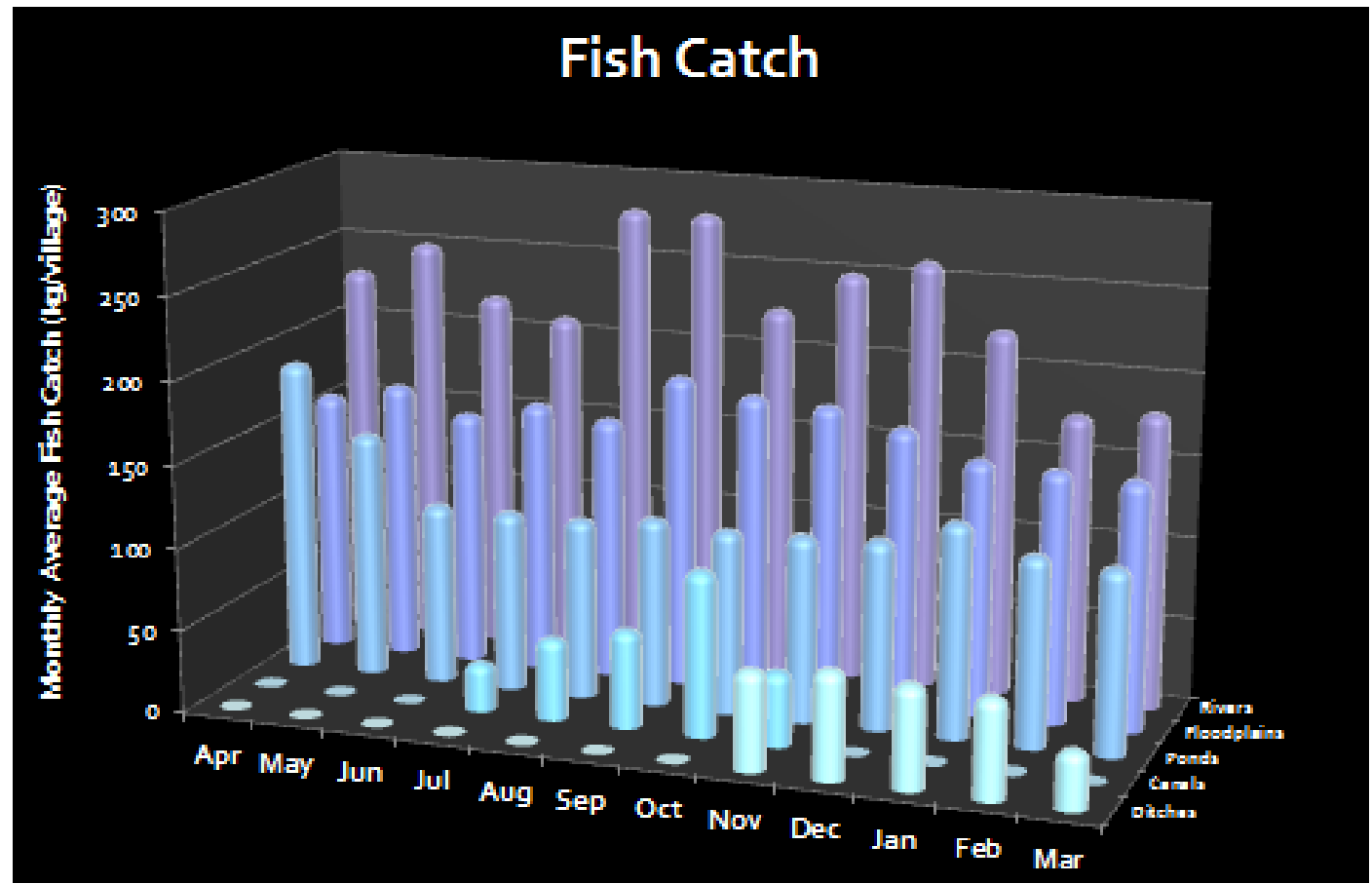

Figure 27. Source- and season-wise fish production in a village. 


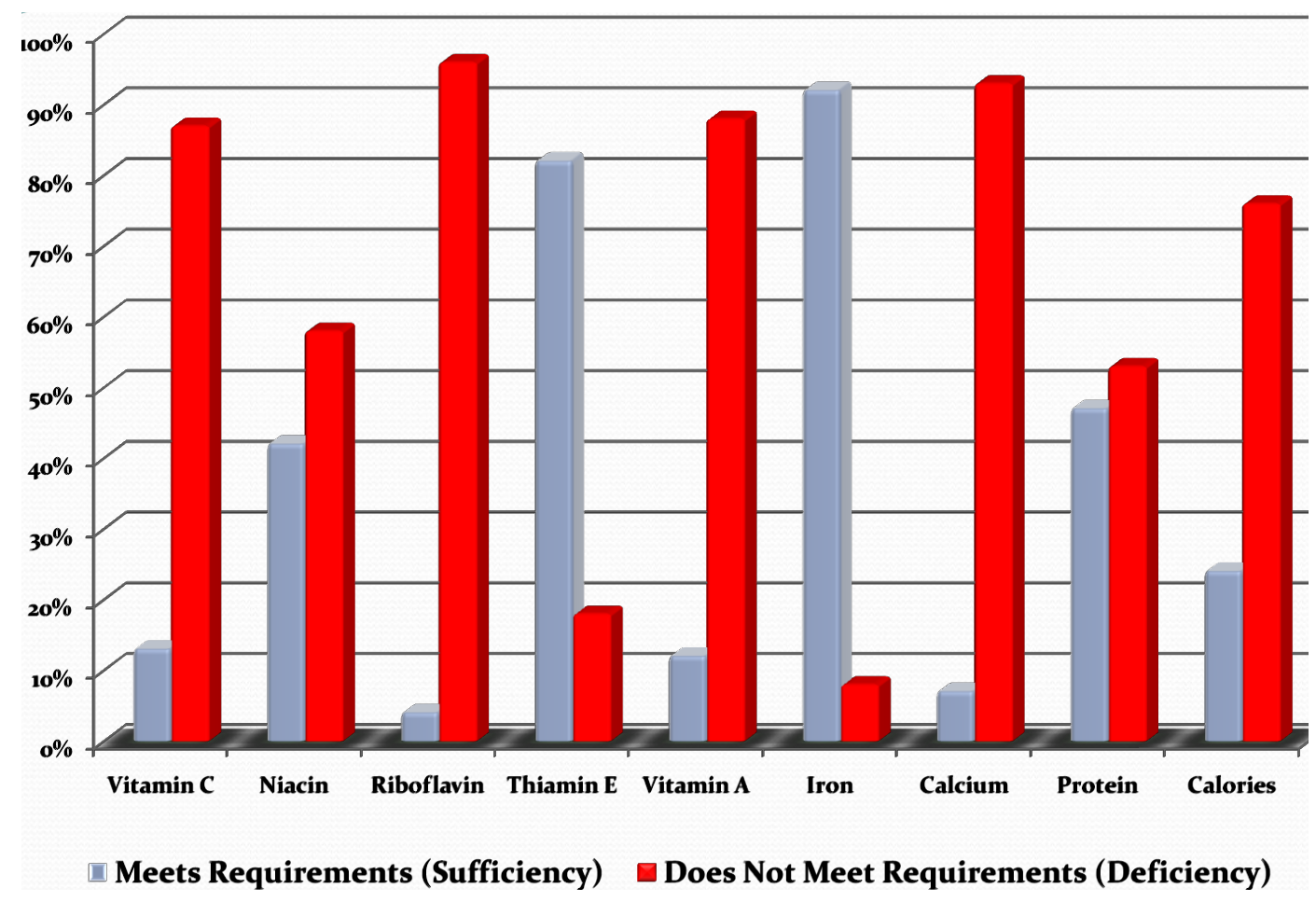

Figure 28. Nutritional deficiency and sufficiency for the project site people, a picture of the eighties

The plot in Fig. 28 shows the sufficiency and deficiency picture of the eighties for a number of nutritional elements including calcium and animal proteins in the food stuff. None of these two nutrients and others were sufficient in the days of abundant fishes. Now population has almost doubled and these resources for nutrition have been scarce, and so priced highly beyond the reach of common people.

For about 10 months, people would fish in the surface water resources to supplement their income and dietary intakes (Hughes et al, 1994). Fish had been the cheapest source of calcium (25\%) (Fig.29) and animal protein (6.25\%) (Fig. 30). one of the indispensables for life. In 1981-82, when the project area-wide population had been 5.6 million (Miah and Samad, 1996), it was found that diets of $76 \%$ and $53 \%$ households did not meet the calcium and protein requirements, respectively (Ahmed and Hassan, 1986). Currently, the project area population has doubled and the cheapest sources for calcium and animal protein have been depleted for the bulk of the population. The post-piracy era up to the end of the last century fish production was annually about $1700 \mathrm{~kg}$ of fish per rural unit, on an average, from surface water resources as opposed to $6700 \mathrm{~kg}$ of fish for the same rural unit in pre-piracy era. No fishes are produced because of rainfall scarcity and irregularity that dries up even the deepest surface water resources. A few pond owners use deep tube-well to water the pond with groundwater for fish cultivation.

Calcium is the principal element $(99 \%)$ in the structure of bones and teeth. It is also one of the most important minerals required for the growth and maintenance and reproduction of the human body. Calcium is also involved in blood coagulation, transmission of nerve impulses, muscle contraction and relaxation, normal heartbeat, stimulation of hormone secretion, and activation on enzyme reactions. A long-term calcium deficiency can lead to rickets, poor blood clotting, and in case of a menopausal woman, osteoporosis in which bone deteriorates and faces the risk of fracture (http://www. calciuminfo.com/osteoporosis/calciudeficiency .aspx; $\quad$ http://en.wikipedia.org/wiki/Calcium; http://www.nof.org/prevention/calcium2.htm). Observations reveal backbone pain in young and old population in the project area. In some villages, multiple stroke patients are observed in the same family (Adel, 1999a).

Protein deficiency syndromes include weight loss, subcutaneous fat decrease, weakness, muscle wasting, edema, and fluid accumulation in serous cavities. Protein deficiency can cause hypotension, bradycardia, and pigmentary changes in the skin. Also, a drop in basal metabolic rate may occur (http://www.oldandsold.com/artic les06/nutrition-6.shtml; http://en.wikipedia.org/wiki/Protein_in_nutrition).

Subcutaneous fat protects the body's temperature. Unusual number of deaths in winter time were reported by Adel (1999a, 2000b, 2003). Those deaths could be related to protein deficiency. 


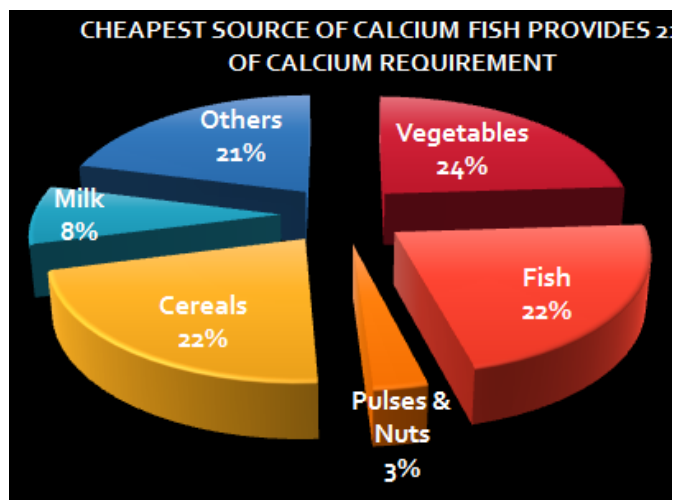

Figure 29. Calcium from the cheap fish resources for the basin people. The sources have been totally depleted.

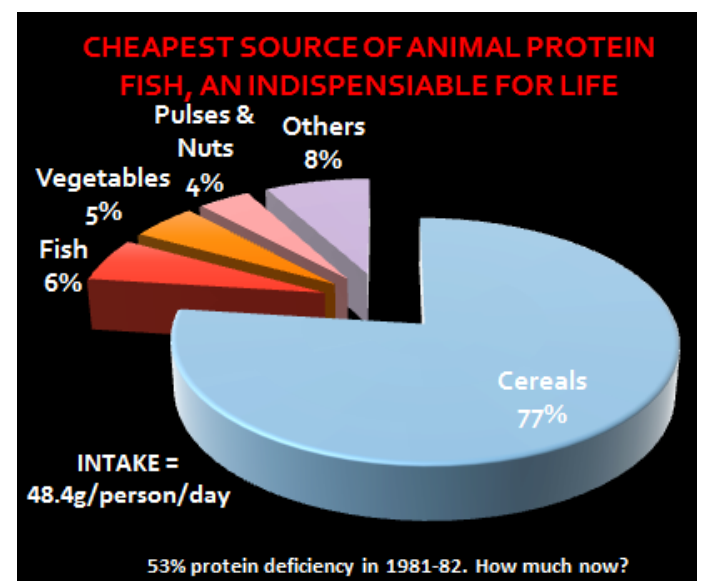

Figure 30. Animal protein, an indispensable of life, from the cheap fish resources for the basin people. The sources have been totally depleted.

Bengal basin are culturally known to be regular eaters of fish and rice. It is no longer true for the basin people. In the pre-piracy period, fish used to be a food item in the meal of all Bangladeshis irrespective of their economic conditions. Today, only economically well-to-do families, which do not represent the bulk of the population, can afford to buy fish.

\subsection{Fishing Gears}

The fishing weapons included those made of bamboo sticks, and bamboo and cane strips, and bamboo and nets,

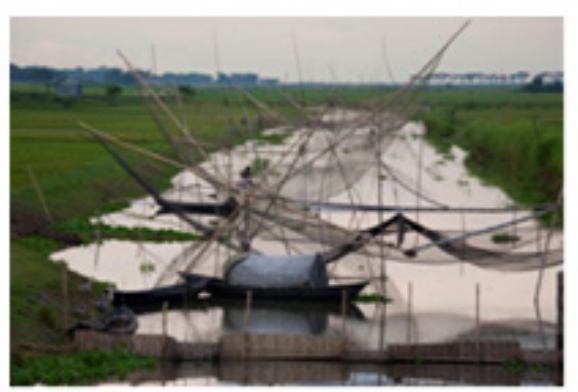

and nets alone. The ones made of sticks were used to catch fish in running water. The ones made of bamboo strips were used to catch fish in still water. Varieties of nets were prepared by professional fishermen. Spawns were caught with nets in the flooded riverst. Other nets were used to catch fish in still water.

Every village used to have some technical hands who were expert in making the fishing gears. The different types of equipment were made of bamboo sticks and a kind of vines called $l o i$. This fibrous vine was used in the raw state and was weather resistant. It was not affected in the same way ropes would due to prolonged inundation in water. These vines would grow in abundance in the jungles. These vines have diameters in the range of $2-4 \mathrm{~mm}$. Their fibrous structure made them strong and lasting for a few years without being brittle. A special kind of bamboo was also available for making the sticks. The length of the sticks would determine the height of the fishing weapons. The length would range in $80 \mathrm{~cm}$ to a few meters for deep current fishing. The diameters of the sticks would be in the range of 2-4 $\mathrm{mm}$. The taller a weapon was the thicker was its sticks. The way the vine used to tie the bamboo sticks is as follows. The vine would be doubled upon itself to have two branches. The bottom of this pair of branches would hold a stick. The vine pairs would then be twisted around each other before feeding in another stick. The spacing between the sticks would be determined by one or more twists in the pair of vine branches. A thinner vine with a single twist is used when the sticks are to be placed densely for catching small fishes.

The gears made of vine and bamboo sticks, and bamboo and cane stripes were ghena, khansoon, and dhial. Each of these was of different sizes and shapes to serve the purpose. The ones made of bamboo and cane stripes were poloi and sharga. These were used in fishing still water. Out of these two, poloi was used in shallow water and sharga in deep water.

Each village would have a few hundreds of ghena, dozens of khalsoon, dozens of dhials, dozens of polios, dozens of nets, and a few shagra, etc. A pre-piracy period fishing scene would look like the one in shown in Fig. 31 Such scenes are unthinkable in clogged river basins like those of the Baral and the Musa Khan. These pictures belong to some live river basins.

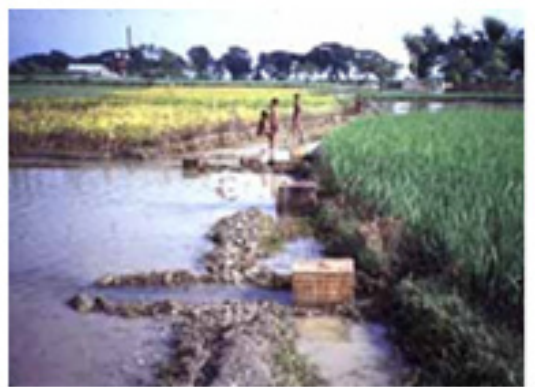

Figure 31. Use of fishing gears in rural fishing. Kholsoons are placed in the opening slots of the and bamboo-strip made fences. http://www.bing.com/images/search?q=Fishing+Nets+in+Bangladesh\&qpvt=Fishing + Ns + in + Bangladesh\&FORM=IGRE\#view=detail\&id=0F51CD0AB 80C6237956A4F0248CB634C7E8D13D9\&selectedIndex=33; http://www.sciencetoymaker.org/bangladesh/food.htm 


\subsubsection{Ghena}

This device would be a cone-shaped. A loi vine of adequate length is doubled on itself. About 10 to 15 bamboo sticks of $60-80 \mathrm{~cm}$ long is tied at one end by a twist at the middle by a twist in the pair of loi branches. In the next phase, each of the sticks is taken at a point and arrested in a twist. This twisting and arresting of the sticks by the vine pairs proceed in helical way in the clock or anticlockwise direction making the inter-stick distance gradually larger. By the time, the twisting reach the other end, the mouth of the weapon becomes wide open and may measure about $10 \mathrm{~cm}$ in diameter.

Ghena is used in shallow water on the border line between two rice fields. Slots are cut to place ghenas in place with its mouth to receive fish moving downstream with water. It can catch punthi, gunchi, koi, chang, gari, tangra, etc. In placing ghenas in canals, a straw fence is set up using bamboo poles. Ghenas are pushed under water across the straw fence (Fig. 29 , right side).

\subsubsection{Khalsoon}

It is a rectangular space surrounded by six walls made of bamboo sticks and loi vine having length, height, and width, and openings in its opposite walls for entrance of fish, and an opening at the top for taking fish out. Its length lies in the range of 1 to $1.5 \mathrm{~m}$ and height in the range of 70 to $90 \mathrm{~cm}$ and width in the range of 25 to $35 \mathrm{~cm}$ (Figs. 30 and 31).
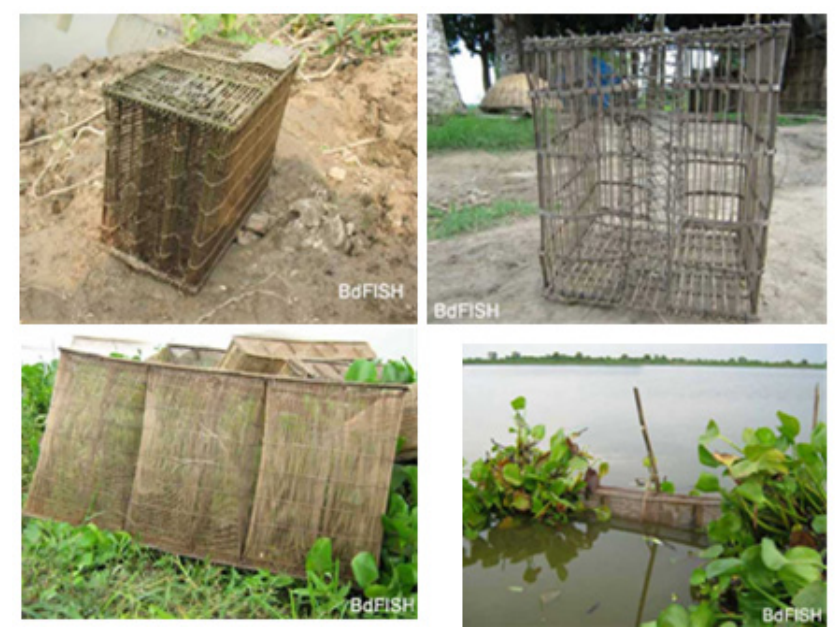

Figure 31. Bamboo fishing gears for different fishes and different places. http://en.bdfish.org/2010/07/fishing-traps-of-halti-beel-natore-bangladesh/. In pre-piracy days, these devices were used in fishing in canals shown in Fig. 18. The Musa Khan and the Baral basins had these scenes, too. For recapitulation, these pictures of some live river basins are shown here.

A rectangular sheet of bamboo sticks of length 70 to $90 \mathrm{~cm}$ and diameter about $2 \mathrm{~mm}$ is woven using loi. A few meter long loi vine is doubled on itself and the bamboo sticks are arrested in the twists of the vine. The spacing between two successive bamboo sticks is made by making some blank twists in the loi vine pair. Two or more vines are similarly used to weave the sheet of bamboo sticks. The bamboo stick sheet is then folded in the shape of the khalsoon. Separate bamboo stick sheets are woven to close the top and bottom part of the structure. A few fish entrance openings are cut on the opposite walls and a fish exit is cut at the top. Strong bamboo sticks are tied around the top and bottom of the structure to make it strong to withstand water current.

One or more khalsoons are put side by side in canals, floodplains, or by the bank of a riverside in shallow waters to catch fish.
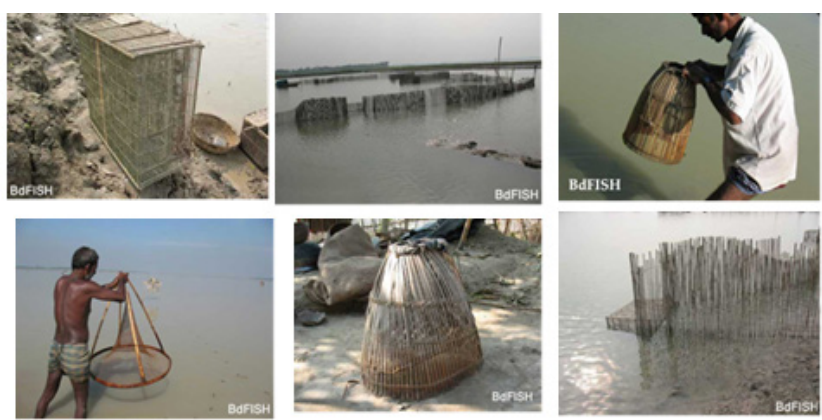

Figure. 32. More fishing gears and their uses in water bodies.http://en.bdfish.org/2010/07/fishing-traps-of-halti-beel-natore-bangl adesh/. These picture belong to some live river basin.

In the rice fields, nets of width $50-60 \mathrm{~cm}$ could stretched across the field for overnight to catch koi fish. Around the boundary of the rice fields, straw and mud fences would be built and slots would be cut in them $60-80 \mathrm{~cm}$ apart to put a ghena and a larger slot would be cut to put a kholsoon or a small size dhial. The caught fishes would be puntni, kholisa, koi, cheng, shoal, tengara, gunchi, etc. shallow water fishes

\subsubsection{Dhials}

These weapons are larger and stronger than khalsoon. One small size dhial is shown in the top right corner in Fig. 30. These were used in the deeply flooded rivers as well as in canals. Its height as about $1.5 \mathrm{~m}$ and the bamboo sticks used had diameters of about $4 \mathrm{~mm}$. Its top and bottom covers have shapes in between a flattened "V" and a triangle. Its V-top is covered with an one-way opening for fish to get into. An outlet for getting fish out is cut in its top cover.

To make dhials, a sheet of about $3.5 \mathrm{~m} \times 1.5 \mathrm{~m}$ is woven out of bamboo sticks and loi in the same way as for khalsoon. About 200 bamboo sticks would be enough to construct the wall of this size dhial. Several parallel loi weaving is required to make this structure strong. Some bamboo strips are tied lengthwise of the sheet of bamboo sticks. The entire sheet is then held upright on the bamboo sticks. The sheet is then bent in the form of a flattened $\mathrm{V}$ with the two ends bent inside such that 15 to $20 \mathrm{~cm}$ of the ends project inside in a converging way. The opening between these two ends is further narrowed by additional bamboo structure having tapering ends pointed inside. This device blocks trapped fishes from escaping out. All large river fishes and medium canal fishes are caught with dhials. Spacing between the bamboo sticks determine the size of fish that can be trapped.

\subsubsection{Angling}


Angling was done by both small and big size rods manually as well as semi-mechanically (Fig. 32, left side). Small rods and hooks were used for catching small fishes. The ones made of large rods and a device for winding string was used in angling in rivers and ponds. Angling was highly enjoyed by kids, adults, and retirees. It was a nice pastime for the elderly people. Available fishes would include koi, cheng, garua, punti, shoal, and tangara.

\subsubsection{Line fishing}

Line fishing was called fishing by dantee, a pastime the author would enjoy in boyhood days after school. A 40-45 $\mathrm{cm}$-long string would have one end attached to a fishing hook and the other end tied to the middle of about the same length of jute stick or some other stick that floats on water would be used in line fishing. Earthworm would be used as the bait. About a dozen of dantees in about an hour's time would be enough to catch a few kilograms of chang, garua, koi, etc.

\subsubsection{Jeala}

In this line fishing, a live bait which could be a frog, a small fish, or a warm, was used. The bottom end of a strong bamboo pole of 4-6 m-long would be securely inserted in the ground near the bank of the water body so that it cannot be uprooted. Frequent rainfall would keep the soil soft enough to push the fishing pole in the ground. A strong string of shorter length with the fishing hook at the end is securely tied to top of the fishing pole. The requirement is that the live bait has to float on the water surface. Boals from rivers and canals would be caught by this technique. Shoals, too, would be caught from ponds, ditches, and canals.

\subsubsection{Shagra}

A shagra is made of closely woven bamboo strips of width 2 to $3 \mathrm{~cm}$. It has a $\mathrm{V}$-shaped bottom having a dimension of 1 to $1.5 \mathrm{~m}$ between the two $\mathrm{V}$-arms. The top part is covered with bamboo strips. A large bamboo handle or a strong rope is attached to its back for controlling its placing as well as dipping in and getting out of water. It is like a huge dust collector we use after brooming. As the river current recedes, shagras are placed under deep parts of the river bed. It is found that some large fish take shelter in shagras. After a few weeks of submersion in water, it is slowly pulled to the side while some helpers remain ready to get into shallow water in case of any indication of fish remaining in the shagra.

\subsection{Nets}

Nets were locally called jals. Both fishermen and non-fishermen could weave them. Fishermen would be expert in weaving several different kinds of fishes.

\subsubsection{V-shaped Net}

The simplest kind of net had V-shaped two crossed handles. The net would occupy the V-space. The net would have fine holes. Fish would be sieved out of water with this net in one scoop after another. A small V-shaped net would catch small fish. A large net would be used to catch small and medium size fishes.
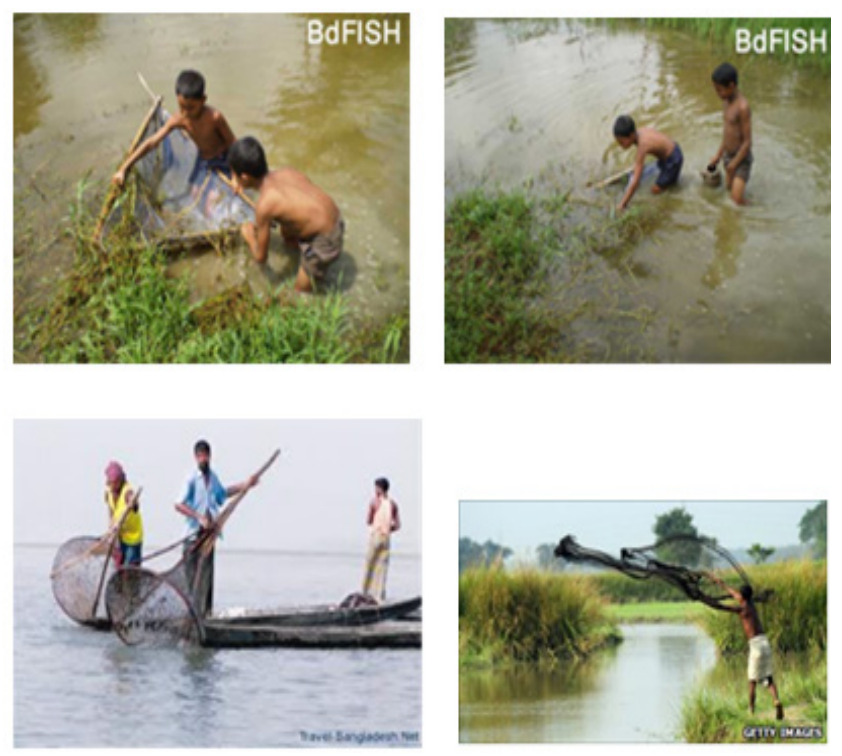

Figure 33. Fishing using V-shaped nets (top two pictures). Both medium and small size fishes like punthi, mola, cheng, koi, magur, shing, tengara, and rarely raikor and small rui; Fishing in large and small water bodies using conical nets and thrown nets (bottom two pictures). These pictures belong to some live river

basin.http://www.bing.com/images/search?q=Fishing+Nets+in+Banglades h\&qpvt=Fishing + Nets + in + Bangladesh \&FORM $=$ IGRE\#view $=$ detail\&id $=E$ A82D869D6A6C0DDB8A75E60A9BD9D4361897993\&selectedIndex $=4$

\subsubsection{Throw net or Tore jal}

When thrown in water in ponds, ditches, floodplains, or rivers, it would spread out in a large V-shape (the first two insets from the left in Fig. 17 and the bottom right inset in Fig. 33). The first two left side insets in Fig. 34 shows their knitting. The bottom of this net has small cylindrical metal shells of 3-4 cm long and half as much the diameter. The shells helps to dip the net in water. The bottom end of the net is folded up inside to make a pocket-like space for fishes to be trapped. Holes in nets are based on the size of the fish planned for catching. The net measures a few meters from the bottom to the tip.

\subsubsection{Fencing nets or Ber jals}

This type of net works like mopping the water body floor (the third inset from the left in Fig. 17). This net is spread from one end of the water body (say pond) to the other end and the ends of the net are pulled forward to corner the fishes near one bank of the water body. The width or depth of the net is larger than the deepest depth of the water body. The net sieves out fishes of water. The net is carried from one end of the water body to the other. The net hole size determines the type of fish to be caught. Professional fishermen had this net. Knitting fishing nets is a forgotten technology for the people of dead river basins. A generational gap will make this totally in oblivion. 

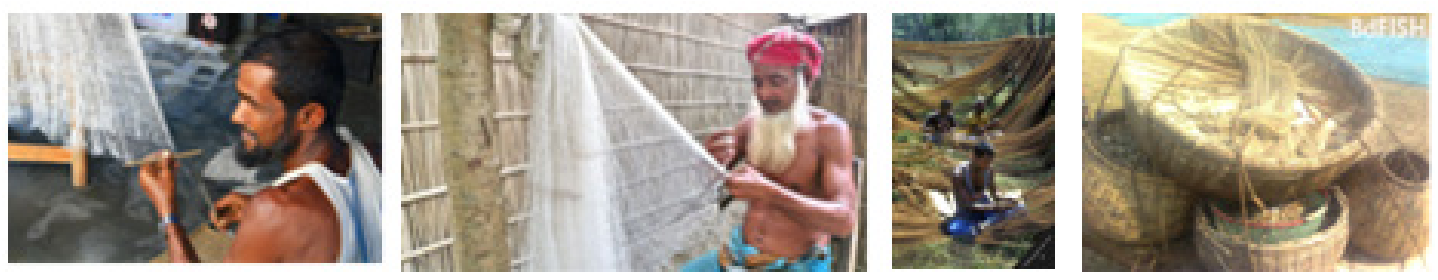

Figure 34. Knitting of nets, a home-taught technique, in some live river basin.

http://www.bing.com/images/search?q=Fishing+Nets+in+Bangladesh\&qpvt=Fishing+Nets+in+Bangladesh\&FORM=IGRE\#view=detail\&id=B3539F9E2 46685D3F8F79943E3F7A3A816C19B77\&selectedIndex=24;

http://www.bing.com/images/search?q=Fishing+Nets+in+Bangladesh\&qpvt=Fishing+Nets+in+Bangladesh\&FORM=IGRE\#view=detail\&id=054270FEB BDE6702E2DD7902BFE06B57E9A86220\&selectedIndex=23;

http://www.bing.com/images/search?q=Fishing+Nets+in+Bangladesh\&qpvt=Fishing+Nets+in+Bangladesh\&FORM=IGRE\#view=detail\&id=B7EEEA70 B84569BC6BB8BAC2373CE78F859A099F\&selectedIndex=0; Bamboo containers for carrying a lot of fishes at a time for transportation to market places. http://www.bing.com/images/search?q=Fishing+Nets+in+Bangladesh\&qpvt=Fishing+Nets+in+Bangladesh\&FORM=IGRE\#view=detail\&id=1DE1D5CB 1C6B36E1E81907C521BBCAD61979CD13\&selectedIndex=20;

\subsubsection{Koijala}

This is a comparatively small size net specially prepared to catch $k o i$ fish. Its length is 6 to $10 \mathrm{~m}$. Its depth or width is less than a meter (Fig. 35). This is used toward the end of the rainy season in October-November.
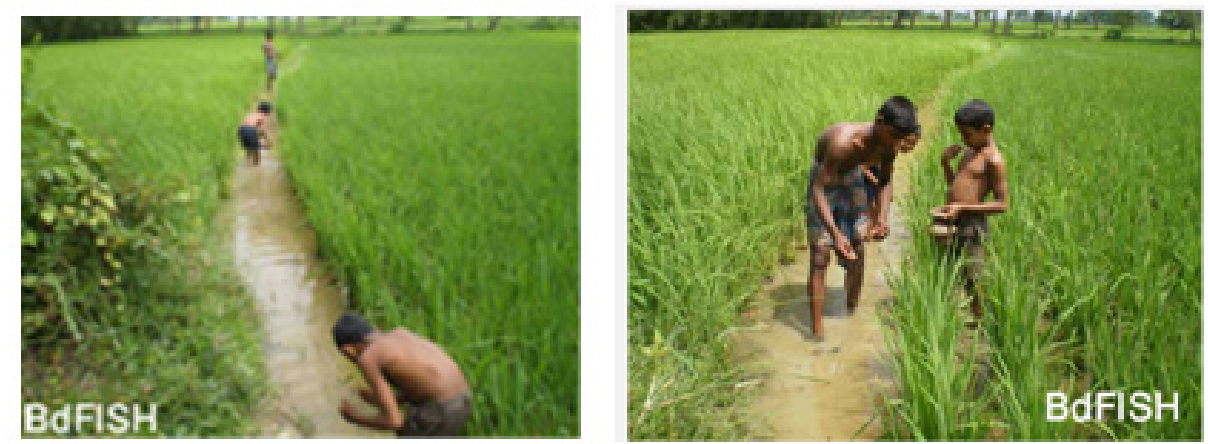

Figure 35. Fishing using Koi jal from flooded rice fields http://en.bdfish.org/2010/09/fishing-technique-rural-areas-northern-bangladesh-monsoon/ Pictures are from some live river basin to show what the Musa Khan and other dead river basins had.
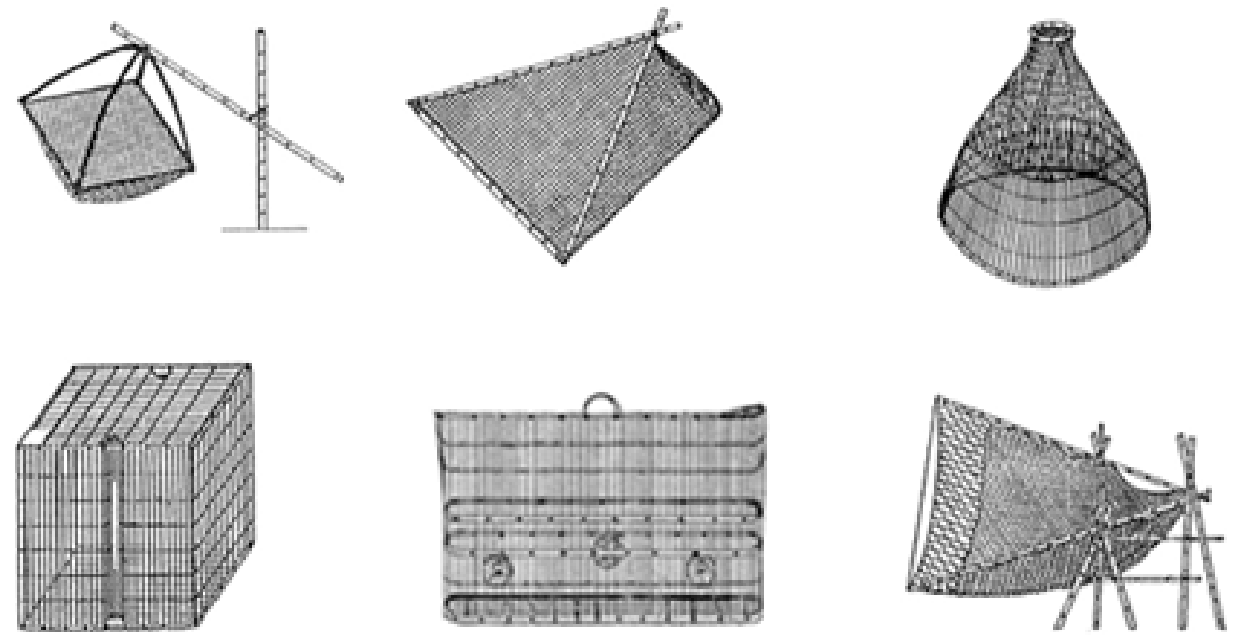

Figure 36. Fishing traps made of bamboos. Top row from the left - dharma jal, thela jal, polo or polio. Bottom row from the left - unta or dhial, bitte or kholsoon, and khora jal. These have different names in different parts of the country. (http://www.banglapedia.org/HT/F_0098.HTM). These devices would be used in fishing in the canals in Fig. 19 that discharge water inland or in shallow water near river bank.

\subsubsection{Dewa}

A third kind of trap people would build on the spot. It was made of earthen dykes high enough to be barely above water. Water would be irrigated out of a few square meter area within the dykes. However, a narrow stream would be maintained by its length or width. Fishes going upstream or downstream, would try to jump over the dyke when they would face it on their 
way. This way fishes would be caught in that dry area within the dykes. Both large and small fishes could be caught by this dyke building method called dewa. This method would be used in shallow water areas toward end of the season when water is receding down, fish population has increased, and the season's bred population has grown up.

People's techniques of making these weapons are in oblivion in the absence of having no use for them.

\subsection{Livelihood Loss}

The Livelihood of common people has been seriously impacted. These categories of people include fishermen, fishing gear makers, boat makers, and the common people who would supplement their income from catching and selling fishes. The number of fishermen pottermen, boatmakers, and fishing weapon-makers dropped from 6,0, 4.04, 5.4 to $0.5,0.5,0.08$, and $1.3 \%$ of the rural population (Fig. 37). Some of these professional are shown in Fig. 38. There would be people having partial income from raising ducks, boatmen to ferry people across the river, boatmen for carrying goods on river ways, etc. etc. Their earning ways have been totally destroyed.

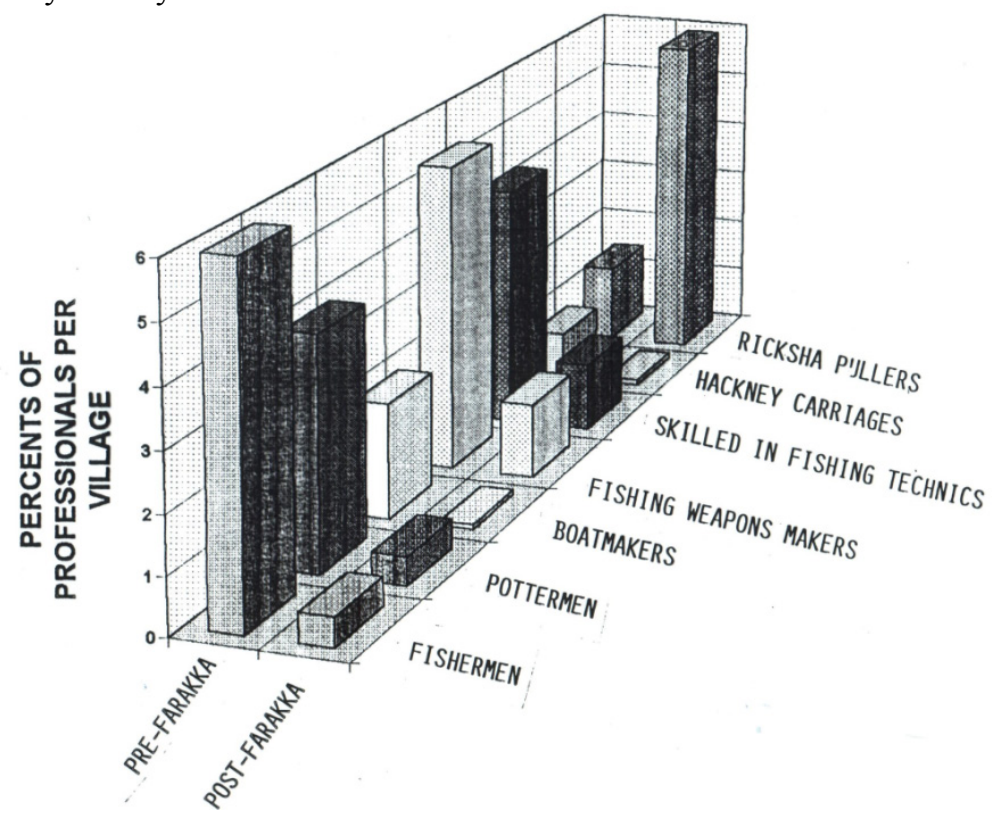

Figure 37. Impact on livelihood of peoples as a result of the upstream water piracy. The only increase had been in the number rickshaw pullers in post-piracy (post-Farakka) days over the pre-piracy (pre-Farakka) days.

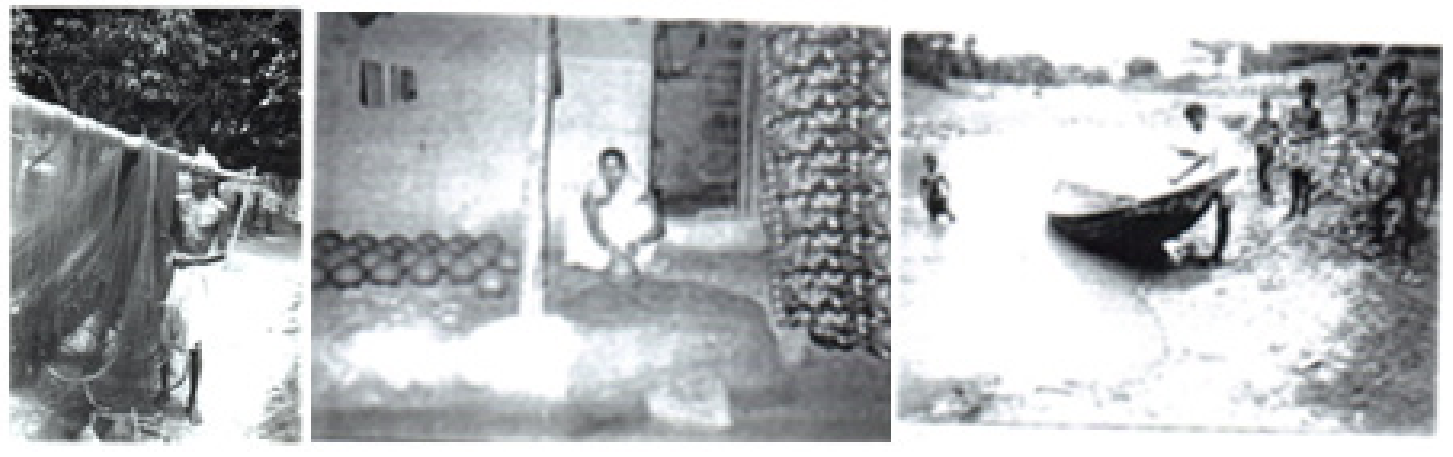

Figure 38. Fisherman (left), potterwoman (middle), and boatmaker (right)

\subsection{Other Dead River Basins}

The above story is a documentation of the lost wetland ecosystem in less than $1,000 \mathrm{sq} \mathrm{km}$. Many more rivers have been dead by the Indian water piracy. These include the Satnai River, the Pakuraj River, the Mahananda Upper, the Teenoi, the Ramchandi, the Khorka, the Kurum, the Gobra, the Petki, the Goramara, the Korotoa in Bogra, the Berang, the Versa, the Tangon, the Talma, the Dahuk, the Chowaia in
Panchgarh, the Kulik in Thakurgaon, the Chepa, the Kongkra in Dinajpur, the Silkee, the Manos, the Dhaijan, the Burikhora, the Naotara, the Dhum, the Buritilka in Neelphamari, the Ghagat, the Akhira in Rangpur, the Phulkumar in Qurigram, and Baral in Rajshahi. Volumes of documents can be prepared of these river basins.

\section{Discussion}




\subsection{Shrinking of Surface Water Resources}

The Ganges water would compensate for about $50 \%$ of the water budget in the basin. A $60 \%$ reduction in the flow of the Ganges has mattered a lot (Adel, 1999a, 2000a, 2000b, 2001, 2002, 2003, 2004a, 2004b, 2005, 2008b). Following the dwindling flow in the Ganges, at the point of origin of the distributaries where the flow velocity drops, there is more time for deposition of sediment because the gravity-induced downward speed becomes stronger than what is in upstream positions in the presence of strong downward speed. This factor accelerated rising accumulation of silts to clog the river mouths.

Deposition of sediment on the river beds and banks causes formation of shoals on the river beds and shrinkage of the river. Elahi and Saleheen (1992) reported distributary areas to be $16.40,16.87,5.67,6.80 .8 .14$, and $7.98 \mathrm{sq} \mathrm{km}$ in 1973, 1978, 1980, 1983, 1984, and 1985, respectively. This accounts for the shrinking of distributaries by more than a factor of two up to the mid-eighties of the last century. Now, more than two decades later, the shrinkage of the distributaries has been proportionately increased.

With the formation of shoals at the mouths of the distributaries, Ganges water cannot flow into some distributary and the flow is cut short in some other distributary. Canals remain dry throughout the year. And the Ganges water cannot reach the floodplains, ponds, ditches, and other low-lying areas. Disruption of the breeding environment due to the shortfall of water in surface water bodies is at the root of making the fish species extinct. Fishes needed the right amount of water including its physical properties like temperature, $\mathrm{pH}$, dissolved oxygen, biological oxygen demand, etc. at the right time for breeding. Every year the aquatics and amphibians had to face a heavy habitat stress. That is what made them extinct.

\subsection{India's Human Action Challenges UNDP's Development Programs}

Indian government planners and policy makers have made UNDP's employment services in the third world countries a challenging one. In this context UNDP's services in the sectors $0 \%$ Poverty Reduction \& Millennium Development Goals (MDG) Achievement, 0\%Crisis Reduction \& Recovery, and 100\%Environment \& Sustainable Development among others are notable (www.undp.org/content/undp/en/home/librarypage/results/f ast_facts/poverty-reduction). Whereas the agency works worldwide in the third world countries in recovery reduction and MDG achievements, crisis reduction and recovery, and environment and sustainable development, in the hope of being the regional super power, India goes to create these formidable problems. Hindustan Builders, the construction company of the Farakka Barrage, has (i) rendered numerous families destitute by affecting their livelihood, (ii) made an uncounted number of aquatics and amphibians extinct, (iii) snatched away downstream country's ecosystem's elixir water, (iv) contaminated the drinking water with arsenic poisoning, (v) made numerous suffer from arsenic contamination, (vi) been causing family break-offs, (vii) been causing one out of five deaths by arsenic poisoning, (viii) created people's malnutrition, (ix) rendered climate extreme and caused outbreaks of environmental diseases that takes a heavy toll, particularly, during the winter, $(\mathrm{x})$ made people suffer from malnutrition, (xi) increased coastal erosion by diverting naturally depositable sediments to the India coast and causing inland deposition of sediment within the downstream country, (xi) caused inland intrusion of the saline water front. The internal immunity system of the downstream country has been broken down making a leeway for natural calamities like the increased occurrences of inland and Bay Bengal tornados that takes a heavy death toll and property loss as well as increased fatalities due to lighting strikes (Adel, 1999a, 1999b, 2000a, 2000b, 2001, 2002, 2003, 2004a, 2004b, 2005, 2008a, 2008b, 2008c, 2012a, 2012b, 2013a, 2013b, 2013c; Miah, 1996a, 1996b, 1996c, 1996d; Miah and Samad, 1996; Rahman, 1997).

\subsection{GDP Needs New Definition}

It is assumed from the definition "A state is a people organized for law within a definite territory" of a state that it has the basic permanent natural resources of land, air, and water. It is also implied in the definition of GDP which was introduced when no state was pirating any other state's natural resources. A state cannot survive when its natural resources are looted. The piracy of natural resources has prompted a new definition of GDP; otherwise GDP of downstream state cannot be compared with that of the pirate state. It will be like comparing apples with oranges because the country having lost the natural resource is like a bottomless basket.

\section{Recommendation}

It is imperative that Hindustan Builders pay compensation to Bangladesh in retrospective effects for all water scarcity-related problems, since water piracy is the central issue and the problems focused in this article arose out of water deprivation. The compensatory actions should come in this order: (i) ) retrospective payback to Bangladesh the earning India made by investing on water resources pirated from Bangladesh, (ii) bearing the cost of dredging the Ganges and its primary, secondary, and tertiary distributaries and their canals, and ponds in Bangladesh, (iii) closing the feeder canal linking the Ganges with the Hooghly, (iv) demolishing the Farakka Barrage, (v) returning the looted and stolen water resources to Bangladesh, (vi) shouldering the cost of fully groundwater recharge, (vii) paying off the cost of groundwater purification until it regains the natural cleaning, (viii) bearing the cost of the treatment of arsenic patients and compensation for the fatalities, (ix) 
retrospective compensation for damages for crops for the generation of extreme weather, $(\mathrm{x})$ paying for the treatment cost of the patients suffering from environmental diseases and mass malnutrition among the basin people, (xi) paying for the cost of the reestablishment of the extinct aquatic and amphibian habitats and the habitants and other flora and fauna, (xii) paying for the rehabilitation of those who lost their livelihoods, (xiii) bearing the cost of desalinization of the inland and coastal surface and groundwater bodies, and (xiv) rebuilding of the coast. If Hindustan Builders do not take any actions, the construction company should be taken to international court by the victims and environmental lawyers if the victim country remains inactive. The world cannot remain a livable place if Hindustan Builders and other builders continue building facilities for upstream water piracy to cause downstream ecocide.

\section{Conclusions}

About $60 \%$ water piracy at the upstream of the Gangs is the reason for surface water depletion in the Ganges basin in Bangladesh. Continued shortfall in the surface water has made the aquatics and amphibian extinct. The short-lived surface water resources are not favorable for the natural breeding and raising of fish resources. Population has increased but the supply of the calcium- and animal protein-bearing sources have been depleted. While the number of people suffering from malnutrition is yet to be determined, the $76 \%$ households having calcium deficiency and the 53\% households having protein deficiency in the early eighties have definitely worsened. People suffer from diseases related to the want of these two nutrients. People have lost their generations-old permanent and seasonal livelihoods that would be provided in the pre-piracy period. People cannot have facilities for recreational activities like water sports, angling, etc. along with religious observance facilities. The solution to the problem of fish availability lies in reactivating the distributaries and their linking canals to floodplains and the return of the pirated water. It is absolutely necessary for Hindustan Builders, the builder of the Farakka Barrage to compensate Bangladesh in retrospective effects including removal of silts from Bangladeshi rivers and canals, closure of the feeder canal, demolition of the Farakka Barrage, return of the looted water and profits made from commercial use, recharging of the groundwater in Bangladesh to the point of its resuming self-purification, rehabilitation of people in their lost professions, compensation of lives lost in arsenicosis, treatment of the suffering people from environmental diseases and arsenicosis, establishment of the lost flora and fauna and normal climate cycle, desalinization of the inland saline water, stoppage of the inland advancement of the saline water front, stopping coastal erosion and building of the coast. If Hindustan Builders do not pay attention, the agency should be sued in international court by the victims.

\section{Acknowledgements}

My sincere thanks are due to those who provided photographs and facts.

\section{REFERENCES}

[1] Adel, M. M. 1999a. The impact of climatic extremes and water shortage upon humanhealth, World Resource Review, vol. 11, no. 4, pp. 576-601Adel, M. M. 1999b. Integrated investigation of the arsenic episode in Bangladesh, Indian Journal of Environmental Protection, vol. 19, no. 9, pp. $652-660$

[2] Adel, M. M. 2000a. Microlevel climate change in the Ganges basin, Journal of the Arkansas Academy of Sciences, vol. 53, pp. 83-91

[3] Adel, M. M. 2000b. Arsenic contamination in the groundwater of Biosphere III: causes and remediation, pp. 71-80, in H. Inyang and V. Ogunro, eds., Proceedings of the Fourth International Symposium on Environmental Geotechnology and Global Sustainable Development, Boston, MA

[4] Adel, M. M. 2001. Effects on downstream water resources from upstream water diversion in the Ganges basin, Journal of Environmental Quality, vol. 30, pp. 356-368

[5] Adel, M. M. 2002. Man-made climatic changes in the Ganges basin, International Journal of Climatology, vol.22, pp.993-1016

[6] Adel, M. M. 2003. Biosphere III: The site of unprecedented ecocide in the Ganges basin, pp. 59-79, in J. Ahmed, ed., National Documentation on the Problems of Arsenic and Farakka, published by the International Farakka Committee, Inc. , New York, NY (invited)

[7] Adel, M. M. 2004a. Impacts from trans-boundary water rights violations in South Asia, pp. 205-214, in R. Murray, K. Jacobson, and S. Anderson, eds., Proceedings of the 2004b Water Management Conference: Water Rights and Related Water Supply Issues, Salt Lake City, Utah

[8] Adel, M. M. 2004b. Upstream water diversion constructions on transboundary rivers, pp. 547-556, in R. Murray, K. Jacobson, and S. Anderson, eds., Proceedings of the 2004 Water Management Conference: Water Rights and Related Water Supply Issues, Salt Lake City, Utah

[9] Adel, M. M. 2005. Background state leading to arsenic accumulation in the Bengal basin groundwater, Journal of Water and Health, vol. 3, no. 4, pp.435-452.

[10] Adel, M. M. 2008a."International migration of Gangetic fishermen in South Asia", International Conference on Environment, Forced Migration \& Social Vulnerability, Bonn, Germany, 9-11 October, 2008.http://www.efmsv2008.org/fil es/International+Migration + of + Ganges + fishermen+In+South+Asia+?menu=12

[11] Adel, M. M. 2008b. Natural river flow obstruction risks groundwater arsenic contamination, UNESCO-Sponsored International Conference on Water Scarcity, Global Changes and Groundwater Management Responses, University of 
California at Irvine, California, 1-5 December, 2008.http://www.groundwater.conference.uci.edu/files/chapt er1/2008 conf AR

[12] Adel, M. M. 2008c. Ordeals to have due share of trans-boundary river water, UNESCO- Sponsored International Conference on Water Scarcity, Global Changes and Groundwater Management Responses, University of California at Irvine, California, 1-5 December, 2008http://www.groundwater.conference.uci.edu/files/chapt er2/2008 conf AR

[13] Adel, M. M. 2012a. Downstream ecocide from upstream water piracy. Am. J. Environ. Sci., 8: 528-548.DOI: 10.3844/ajessp.2012.528.548, URL:

[14] Adel, M. M. 2012b. Ecosystems sustainability challenges from international river water plunderage, pp. 58-66. in S. Rab ed. Proceedings of the 3rd ABC Convention, Astoria World Manor, Astoria, Queens, NY, June 23-24, 2012

[15] Adel, M. M. 2013a. Treeteo Jobjagater ek Musa Khanr Kahinee (Story of the Musa Khan in the Bio-World III) in press for publications by Dibbo Prakash, 32/2 Khan Bangla Bazar, Dhaka - 1100, Bangladesh

[16] Adel, M. M. 2013b. An Amazing Strategy for Upstream Water Piracy and Its Remedial Measures"(accepted in Environmental Justice)

[17] Adel, M. M. 2013c. Upstream water diversion contaminates downstream water, Environmental Justice Vol.6, No. 3, 2013. Mary Ann Liebert, Inc. DOI: 10.1089/env.2013.0008

[18] Adel, M. M. 2013d. Farakka Barrage, the greatest ever riparian bluff for upstream water piracy, Academia Journal of Environmental Sciences 1(3):036-052, March 2013;

[19] Adel, M. M. 2013e. Jaladasyupana (Water Piracy) published by Dibbo Prakash, 32/2 Khan Bangla Bazar, Dhaka - 1100, Bangladesh

[20] Adel, M. M. 2013f. Environmental pollution through indiscriminate arsenic waste disposal, Journal of Ecological Science Research, Vol. 1(1), pp. 1-26

[21] Ahmed, A. H., and N. Hassan. 1986. Nutrition Survey of Bangladesh 1981-82. University of Dhaka, Dhaka, Bangladesh.

[22] Begum, K. , 1988. Tension over the Farakka Barrage, The University of Press Ltd., Dhaka, Bangladesh.

[23] Bindra, S. S., 1982, Indo-Bangladesh Relations, Deep and Deep Publications, New Delhi, India.

[24] Elahi, M., and M. Saleheen, Riverbank erosion and impact study, Department of Geography, Jahangir Nagar University, Dhaka, Bangladesh, 1992
[25] Haque, M. A., 2003. Bullying small ones/human rights violation in Bangladesh In: J. U Ahmad (ed.) National Documentation on the Problems of Arsenic and Farakka $\mathrm{p}$. 99-104, Published by International Farakka Committee, Dhaka, Bangladesh

[26] Hebblethwaite, G. 1997. The impacts and implications of the Farakka barrage upon Bangladesh. B. S. thesis, University of New Castle upon Tyne, UK.

[27] Hollander, M. and D. A. Wolfe. 1999. Nonparametric Statistical Methods, John Wiley and Sons, Inc. New York, 178-179.

[28] Islam, M. S., and M. A. Hassan. 1983. An account of the fishes of the Padma near Rajshahi, Rajshahi Fisheries Bull. $1: 1-31$

[29] Miah, M. A. 1996a. Farakka Barrage: an unprecedented environmental disaster in theGanges basin, pp. 18-31, in T. S. Rehman, ed., Perspectives of the Thirty-Year Water-Sharing Treaty, Bangla Bazar Publisher, Dhaka, Bangladesh, (invited article)

[30] Miah, M. A. 1996b. Signs of climatic changes in Ganges basin, Bitchitra, vol. 10, pp. 14-21 (Cover page article)

[31] Miah, M. A. 1996c. Ecocide in the Ganges basin, The Message, pp. 13-14, May 1996

[32] Miah, M. A. 1996d. The water crisis in Bangladesh: a challenge to integrated water management in urban areas, Environmental Research Forum, vol. 3-4, pp. 69-86,

[33] Miah, M. A. and M. A. Samad, 1996 History of the environment of Bangladesh , pp. 214-227, in W.Schroder and W. Calocino, eds., Global Change and History of Geophysics, Bremen- Roennebeck, Germany

[34] Rahman, T. S. (ed.), 1997. Gangar Panichukti Prekkhit o Sombhabona, Published by A. M. Haque of Mowla Brothers, Dhaka, Bangladesh

[35] Sattar, M. A., 1996. Farakka: Bangladesher Bhagya Zekhane Bondi, Padma Prakashani, Dhaka, Bangladesh

[36] Sattar, M. A., 1998. Bangladesh-Bharat Ovinno Nodir Pani Sankot (Bangladesh-India Transboundary River Crisis), Tofazzel Hossain Vishwya Sahitya Bhaban, Banglabajar, Dhaka, Bangladesh.

[37] Sufian, A. K., 1993. Farakka Barrage - An Overview, in Proceedings of the International Seminar on Farakka Barrage, Forakka Committee (ed.), October 10. Columbia University, New York, pp. 25-26. 